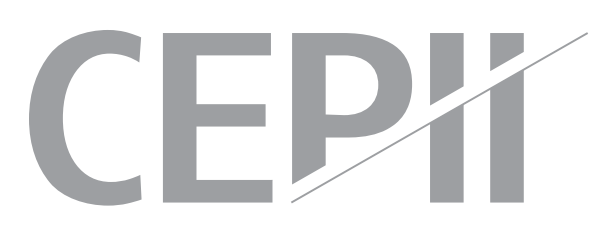

\title{
Minimum Wages and the Labor Market Effects of Immigration
}

\author{
Anthony Edo \& Hillel Rapoport
}

\section{Highlights}

- This paper investigates how the prevalence of minimum wage affects the labor market impact of immigration.

- Our identification strategy uses the non-linearity created by the coexistence in the United States of stateand federal-level minimum wages.

- We find that immigration has relatively small detrimental effects on the wages and employment outcomes of competing native workers.

- However, the impact of immigration on natives' labor market outcomes is more negative in states where the effective minimum wage is relatively low. 


\section{Abstract}

This paper exploits the non-linearity in the level of minimum wages across U.S. States created by the coexistence of federal and state regulations to investigate how the prevalence of minimum wages affects the labor market impact of immigration. We find that the effects of immigration on the wages and employment of native workers within a given state-skill cell are more negative in U.S. States with low minimum wages (i.e., where the federal minimum wage is binding). The results are robust to instrumenting immigration and state effective minimum wages, and to implementing a difference-in-differences approach comparing U.S. States where effective minimum wages are fully determined by the federal minimum wage over the whole period considered (2000-2013) to U.S. States where this is never the case. This paper thus underlines the important role played by minimum wages in mitigating any adverse labor market effects of low-skill immigration.

\section{Keywords}

Immigration, Minimum Wages, Labor Markets.

\section{JEL}

F22, J61.

\section{Working Paper}

\section{CEPI}

CEPII (Centre d'Etudes Prospectives et d'Informations Internationales) is a French institute dedicated to producing independent, policyoriented economic research helpful to understand the international economic environment and challenges in the areas of trade policy, competitiveness, macroeconomics, international finance and growth.
CEPII Working Paper

Contributing to research in international economics

C C CEPII, PARIS, 2017

All rights reserved. Opinions expressed in this publication are those of the author(s) alone.

$\begin{array}{ll}\text { Editorial Director: } & \text { CEPII } \\ \text { Sébastien Jean } & \begin{array}{l}\text { 113, rue de Grenelle } \\ 75007 \text { Paris }\end{array} \\ \text { Production: } & +33153685500 \\ \text { Laure Boivin } & \text { www.cepii.fr } \\ \text { No ISSN: } 1293-2574 & \text { Press contact: presse@ }\end{array}$




\title{
Minimum Wages and the Labor Market Effects of Immigration
}

\author{
Anthony Edo² \& Hillel Rapoport ${ }^{3}$
}

\section{Introduction}

The effect of immigration on the labor market outcomes of native workers is one of the most controversial issues in modern labor economics (Borjas, 2014). Early investigations (Card 1990; Altonji and Card 1991; Hunt 1992; Friedberg and Hunt 1995) concluded that the effect of immigration on the labor market outcomes of natives is small. ${ }^{4}$ By using spatial correlations between wages (or employment) and measures of immigrant penetration, these studies could however lead to misleading interpretations (Borjas, Freeman, and Katz, 1997; Dustmann, Fabbri, and Preston, 2005). Obviously, labor is not an exception to the law of supply and demand. If wages do not fall after an immigration-induced increase in labor supply, this could be due to any of the following departures from the standard model. First, immigrants and native workers may not be perfect substitutes, either because they have different education levels or, within a given education category because they have complementary skills (Peri and Sparber, 2009; Ottaviano and Peri, 2012). Second, the labor supply shock caused by immigration may not be exogenous, especially if immigrants sort themselves to destinations with high wage and employment prospects, or if native workers respond to immigration by emigrating to other local labor markets, therefore violating the ceteris paribus assumption. And third, labor market imperfections such as wage rigidities, unions, or other institutional characteristics may prevent wages or employment to adjust.

\footnotetext{
${ }^{1}$ We thank Simone Bertoli, George Borjas, Frédéric Docquier, Jesús Fernández-Huertas Moraga, Joan Monras, Giovanni Peri, Jan Stuhler, Camilo Umana Dajud, Madeline Zavodny, conference audiences and seminar participants at CEPII, OECD, ESPE, LACEA, IZA, PSE applied lunch seminar, RWI-Essen, The Kiel Institute, University of Chile in Santiago and Carlos III University Madrid for useful comments and suggestions. Any errors which remain are our own.

${ }^{2}$ CEPII, France. E-mail: Anthony.Edo@cepii.fr.

${ }^{3}$ Paris School of Economics, Université Paris 1 Panthéon-Sorbonne and CEPII, France. E-mail: Hillel. Rapoport@psemail.eu.

${ }^{4}$ See Borjas (2017); Peri and Yasenov (2015) for a reassessment of Card's (1990) "Mariel boatlift" article.
} 
Focusing on workers with similar observable skills (education and experience) and accounting for the fact that natives may respond to immigration by moving to other localities, Borjas (2003) developed the national skill-cell approach (i.e., considering skill-cells defined in terms of education and experience at the national level). ${ }^{5}$ This approach has then been used in numerous studies, with mixed conclusions as to how native workers' wages and employment respond to immigration-induced labor supply shifts (Aydemir and Borjas, 2007; Manacorda, Manning, and Wadsworth, 2012; Bratsberg, Raaum, Røed, and Schøne, 2014; Ortega and Verdugo, 2014). The endogeneity of immigration to economic conditions (i.e., the fact that foreign-born workers are not randomly distributed across labor markets but tend to be mostly attracted to localities and skill-cells where wages and employment are relatively high), on the other hand, has generally been addressed by using instrumental variable estimations inspired by Card (2001)'s "shift share" approach exploiting historical distribution of immigrants across destinations. Finally, as mentioned above, labor market institutions (e.g., collective wage bargaining, unemployment benefits, minimum wages) may be a third factor undermining our ability to detect any labor market impact of immigration. By affecting wage-setting mechanisms as well as reservation wages, labor market institutions could have an effect on the responsiveness of wages (and/or employment) to immigration-induced increases in the labor supply (D'Amuri, Ottaviano, and Peri, 2010; Brücker, Hauptmann, Jahn, and Upward, 2014; D'Amuri and Peri, 2014; Dustmann, Schönberg, and Stuhler, 2016). ${ }^{6}$ For example, it could well be that the impact of immigration on the wages of native workers are limited not because immigration has a neutral effect, but because of wage rigidities. In rigid labor markets indeed, immigration could instead

\footnotetext{
${ }^{5}$ Other studies divide the national economy into different occupation groups - see e.g. Friedberg (2001); Card (2001); Orrenius and Zavodny (2007); Steinhardt (2011). See also the important contributions by Peri and Sparber $(2009,2011 b)$ regarding the role of immigration on the occupational upgrading of native workers.

${ }^{6}$ Felbermayr, Geis, and Kohler (2010); Brücker and Jahn (2011); Edo and Toubal (2015) also account for the sluggish adjustment of wages when investigating the labor market effects of immigration in France and Germany.
} 
affect the level of unemployment (Angrist and Kugler, 2003; Glitz, 2012; Edo, 2016). ${ }^{7},{ }^{8}$

To sum up, the main econometric issues when estimating the labor market effects of immigration identified so far in the literature are: the diffusion effect caused by "native flight", the endogeneity of immigration to labor market conditions, and the institutional factors that limit wage flexibility, possibly preventing wage adjustments to immigration. Our paper contributes to this literature by exploiting the existence of different minimum wages across local labor markets within one country, the United States, while at the same time implementing a skill-cell and a shift-share methodology. Our identification strategy uses the non-linearity created by the coexistence in the United States of state- and federal-level minimum wages. Some U.S. States set their minimum wage at a level which is systematically higher than the federal minimum wage, while in other U.S. states the federal standard applies. This means that the successive rises in the federal minimum wage from $\$ 5.15$ before 2008 to $\$ 7.25$ after 2010 not only strongly increased the number of workers covered by the minimum wage in the U.S. as a whole but did so disproportionately in low-minimum wage states (i.e., those having an effective minimum wage equals to federal standards). We follow Card (1992); Card and Krueger (2000); Baskaya and Rubinstein (2012) in taking advantage of the fact that these increases tend to be exogenous to state economic conditions and ask how minimum wage changes impact the labor market effects of immigration on natives' outcomes.

More precisely, we use U.S. States and education-experience groups to define labor markets and exploit two complementary empirical strategies. Our first empirical strategy uses the state-skill panel data now standard in the U.S. immigration literature (Borjas, 2014). We use the changes in immigration that occur within state-skill cells to estimate the effects of immigration on natives' wages, employment, and out-of-state migration, as well as to identify the role

\footnotetext{
${ }^{7}$ In particular, Angrist and Kugler (2003) investigate how rigidities in product and labor markets (e.g., business entry costs, employment protection, firing costs, replacement rates) can affect the employment of natives in response to immigration. In a panel of European countries, they find that the negative employment effect induced by immigration is exacerbated in countries with high rigidities. As rigid institutions reduce the total size of natives' employment, the negative wage impact of immigration is more concentrated, thereby contributing to greater employment losses due to higher incentives to leave the labor market. In the case of a minimum wage, the consequences of immigration on the labor market outcomes of natives may be different. In fact, the workers paid at the minimum wage cannot experienced any wage losses and, as a result, should not have any incentives to leave the labor market. By mitigating the negative wage impact of immigration, minimum wages could therefore reduce the detrimental employment consequences of immigration.

${ }^{8}$ See also the contribution by Naidu, Nyarko, Dhabi, and Wang (2015) on how search frictions can affect the labor market outcomes of immigrant workers.
} 
played by the level of States' minimum wages in shaping these effects. Our second empirical strategy is derived from the minimum wage literature and exploits a difference-in-differences (DiD) approach. We take advantage of the incremental increases in the federal minimum wage between 2007 and 2010 to analyze the within-cell effects of immigration on natives' outcomes in States where the federal minimum wage is binding (the treatment group) versus a control group of states that did not experience any change in their effective minimum wages over that same period. ${ }^{9}$

In both empirical strategies, we account for the various potential biases that arise from the endogeneity of immigrants' location choices. We follow Card (2001); Cortes (2008); Peri (2012), and use the historical distribution of immigrants by country of origin across U.S. States (taken from the 1980 U.S. Census) as an instrument for current immigrant penetration. This instrument is based on the fact that immigrants' location decisions are partly determined by the presence of earlier immigrants whereas the historical distribution of immigration is in principle uncorrelated with contemporaneous changes in labor market outcomes and economic conditions at the stateskill group level. It is, however, important to emphasize that our empirical strategies capture the direct partial effects of immigration on the wages and employment of similarly skilled natives in the short-run. By construction, we neglect any potential cross-group complementarities, as well as any capital-stock adjustments that could have positive wage impacts for all native workers (Dustmann and Glitz, 2015; Lewis, 2011; Ottaviano and Peri, 2012). These channels should be taken into account when discussing the impact of immigration on the labor market outcomes of the average native worker.

We find that immigration has negative effects on the wages and employment of native workers within the same state-skill group, but that these effects are less negative when the State's effective minimum wage is high. This suggests that immigration has stronger negative effects on natives' outcomes where there is less wage-rigidity. High minimum wages therefore exert a protective effect on natives' wages and employment, making them less sensitive to competition from immigrants. Using data mostly from the American Community Survey for the 2000-2013 period, we find that a 10 percent increase in the size of a state-skill group due to the entry of immigrants reduces the mean weekly wage of native workers in that group by 0.2 percent, and by 1 percent after instrumenting (the corresponding elasticities are respectively -0.02 and

\footnotetext{
${ }^{9}$ In other words, we estimate the difference between the differences in the labor market effects of immigration before and after the federal minimum wage rises in the affected $v$. unaffected states.
} 
$-0.1) .{ }^{10}$ Our point estimate is close to Borjas (2014, chapter 4) who uses U.S. census data from 1960 to 2010 and finds a wage adjustment of 1.3 percent at the state-skill level. Nevertheless, when we focus on low-education, low-experience groups (e.g., up to completed high school with less than 10 years of work experience), our point estimate is about four times higher than our baseline, corresponding to a wage elasticity comprised between -0.3 and -0.4 . Our objective, however, is not to provide yet another estimate of the wage response to immigration but to investigate the role of minimum wages in determining such response. Interestingly, we find that a $\$ 1$ increase in the minimum wage brings the wage elasticity to immigration from -0.1 to -0.03 for the whole sample and from -0.3 to -0.2 when focusing on low-educated and low-experienced groups. Moreover, the protective effects of the minimum wage also differ across U.S. States according to their minimum wage level. The elasticity of wages to immigration goes from - 0.2 in States with the lowest minimum wages (e.g., Alabama, Florida, Texas) to virtually zero in States with the highest minimum wages (e.g., Alaska, Massachusetts, Washington).

Regarding employment, we find that a 10 percent immigration-induced increase in labor supply reduces the employment rate of competing natives by 0.3 percent, and by 0.9 percent after instrumenting. When focusing on low-skilled native workers, we find an employment reduction of about 2.5 percent in the IV specification. This magnitude is consistent with the fact that the negative wage impact induced by immigration is stronger for the low-skilled native workers (Orrenius and Zavodny, 2008; Smith, 2012). Minimum wages also appear to have a protective effect on natives' employment. Indeed, we find that a $\$ 1$ increase in the minimum wage brings the employment elasticity to immigration from -0.09 to -0.05 for the whole sample and from from -0.25 to -0.18 when focusing on low-educated and low-experienced groups. Moreover, the elasticity of employment to immigration goes from -0.3 for the lowest minimum-wage states to -0.1 for the highest minimum-wage states.

In our regressions, we include time-varying state fixed effects to control for local economic conditions. However, it is impossible to exclude the possibility that States' effective minimum wages are not endogenous to changes in economic conditions at the state-skill level. In order

\footnotetext{
${ }^{10}$ As explained earlier, one identification issue relates to the "native flight" caused by immigration. The outmigration of natives from states that are most affected by immigration should re-equilibrate local labor market conditions, thereby contributing to the understate the adverse labor market effects of immigration. In the Appendix (Section B), we investigate the impact of immigration on the native flight and find very small or insignificant effects. As a result, native internal migration resulting from immigration-induced changes in supply at the state-skill cell level is unlikely to bias our estimated effects on natives' wages and employment.
} 
to account for the potential endogeneity of States' effective minimum wages, we follow Baskaya and Rubinstein (2012) and use the federal minimum wage as instrument. In fact, federal minimum wage adjustments affect differentially the effective minimum wage across states and are arguably exogenous to economic conditions at the state level.

We then implement a difference-in-differences analysis by exploiting the successive rises in the federal minimum wage over the period considered, comparing states where federal standards apply (i.e., our treatment group) to unaffected states (i.e., our control group). ${ }^{11}$ We find that the successive rises in the federal minimum wage between 2007 and 2010 strongly mitigated the adverse labor market effects of immigration in low minimum wage states relative to high-minimum wage states (i.e., in the treatment v. the control group). Over the period, our estimates indicate that these federal adjustments reduced the wage and employment elasticities to immigration in low-minimum wage states respectively by 9.2 percent (from -0.61 to -0.56 ) and 13.8 percent (from -0.32 to -0.28 ).

The remainder of this paper is organized as follows. The next section proposes a simple diagrammatic discussion of the theoretical impact of immigration on local labor markets when a binding minimum wage prevails. Section 3 describes the data, presents our identification strategies and discusses the main identification issues. Section 4 investigates the impact of immigration on the wages and employment of competing native workers and shows that this impact largely depends on whether the effective minimum wage in a given state is higher or equal to the federal standard. In Section 5, we first provide a placebo test to show the robustness of our main results: we split our sample of workers into a low- and a high-wage group and show that our results are driven by the low-wage group, the one for which, arguably, minimum wages are most relevant. Section 5 then explores this question further by focusing on lowskilled workers (i.e., workers with the lowest levels of education and work experience). Section 6 implements our difference-in-differences approach by exploiting the successive changes in the federal minimum wage policy and supports our conclusions that minimum wages protect native workers against competition from immigrant workers with similar skills. Finally, Section 7 concludes.

\footnotetext{
${ }^{11}$ Under the plausible assumption that any changes in the labor market effects of immigration in the treatment and control groups would have been the same if it was not for the treatment (the common trend assumption), our DiD estimation can support a causal interpretation.
} 


\section{Theoretical Background}

A textbook model of a competitive labor market has clear implications as to whether and how natives' wages and employment should respond to immigration in the short-run (i.e., when the stock of capital is assumed to be fixed). Immigration of workers with certain skills should reduce the wages and employment of workers with similar skills and increase the wages and employment of workers with complementary skills. This is illustrated in Figure 1: the immigrationinduced supply shift leads to lower wages from $W_{0}$ to $W_{1}$. At this lower wage, fewer native-born workers will be willing to work - some natives will find it profitable to stop working; as a result the employment of native workers will fall from $N_{0}$ to $N_{1}$. Although natives' employment is reduced, total employment is increased from $N_{0}$ to $E_{1}$. Obviously, the employment response to changes in wages depends on the elasticity of the labor supply.

How does the introduction of a (binding) minimum wage $\tilde{W}\left(W_{1}<\tilde{W}<W_{0}\right)$ affect these conclusions? One can see from Figure 1 that the impact of immigration on natives' outcomes is now weaker: the decline in natives' employment is reduced (it falls from $N_{0}$ to $N$ ); total employment still increases (from $N_{0}$ to $\tilde{E}$ ) but less than in the competitive case. In addition, one can see that at the new equilibrium wage $\tilde{W}$ corresponding to the minimum wage, there is some involuntary unemployment $\tilde{U}$ (coming from immigrants). The introduction of a minimum wage, therefore, mitigates the negative effects of immigration on natives' labor market outcomes.

The main conclusions of this simple framework can thus be summarized as follows:

- In the competitive case: an increase in the number of immigrants $M$ decreases the wages of competing natives and, therefore, reduces their employment. Formally, $\delta W / \delta M \equiv$ $\xi_{W}<0$ and $\delta N / \delta M \equiv \xi_{N}<0$, where $\xi_{w}$ and $\xi_{N}$ denote the wage and native employment responses to immigration, respectively.

- In the case of a binding minimum wage: the negative effects of immigration on natives' labor market outcomes are smaller than in the competitive case.

This leads to the following testable implications:

- Implication 1: a higher minimum wage should reduce the negative impact of immigration on natives' wages $\left(\delta \xi_{W} / \delta \tilde{W}>0\right) . .^{12}$

\footnotetext{
${ }^{12}$ In other words, "the presence of a binding minimum wage (a wage floor) lessens the adverse impact of immi-
} 
Figure 1: The Short-run Impact of Immigration on Equally Skilled Natives

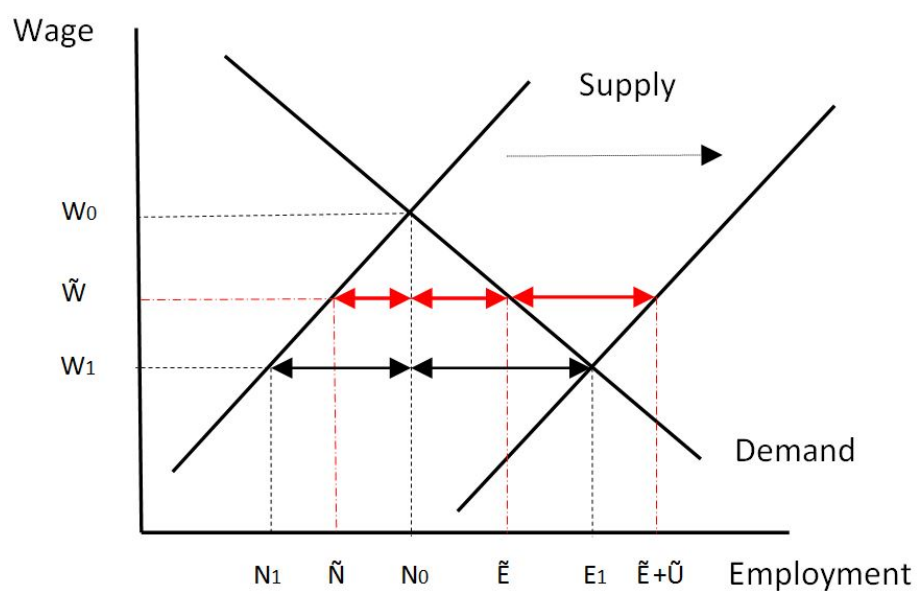

- Implication 2: a higher minimum wage should reduce the negative impact of immigration on natives' employment $\left(\delta \xi_{N} / \delta \tilde{W}>0\right)$.

As discussed, an important prediction of standard theory is that an immigration-induced increase in the labor supply should decrease the employment of competing natives. The reduction in natives' employment may translate into a rise in (voluntary) unemployment and/or inactivity. Let us denote the level of inactivity by $I$. If the participation rate is strongly responsive to a decline in wages, immigration will mainly increase inactivity. Alternatively, a lower wage may not lead to increased inactivity if the participation rate is insensitive to wage changes. The empirical section of this paper will study these responses by using two measures of natives' employment: as a share of the labor force, $N /(N+U)$; and as a share of the working age population, $N /(N+U+I)$. Any difference in the two responses will be indicative of differential adjustment in natives' employment through either unemployment or inactivity. However, it is theoretically unclear whether a higher minimum wage will favor an adjustment through unemployment or inactivity. Indeed, a higher minimum wage has an uncertain effect on the expected wage of an unemployed worker: higher wages conditional on working should favor remaining in the labor force and searching for a new job while lower employment prospects should instead lead to more inactivity (Zavodny, 2014).

In summary:

gration on wages" (Zavodny, 2014, p.3). 
- Implication 3: immigration should reduce natives' employment both through increased unemployment and through increased inactivity; however, it is a priori unclear how higher minimum wages affect the choice between unemployment and inactivity.

This simple framework indicates that minimum wages tend to protect employed natives from immigrant competition. This is precisely what we test in the present paper. While protecting insiders from competition, a high minimum wage may be detrimental to non-employed natives. In fact, it may also be that an immigration labor supply shock decreases employment opportunities (higher unemployment duration and lower probability to find a job) of non-employed natives when a high minimum wage prevails. As our ACS data do not contain the employment status of individuals one year prior to the survey and the unemployment duration of individuals, we cannot test for these effects.

Finally, some natives could respond to immigration by moving to other labor markets (Borjas, Freeman, and Katz, 1997; Card, 2001). This native migration response (or "native flight") should be limited under high minimum wages for the simple reason that high minimum wages mitigate the negative labor market effects of immigration (which cause the flight in the first place), as we have seen. In other words:

- Implication 4: immigration should displace native workers to other labor markets.

- Implication 5: Higher minimum wages should act to reduce "native flight."

These implications are tested in our empirical analysis. As shown in Borjas (2014, Chapter 6 ), these effects depend on the geographic size of local labor markets. The native migration response should be stronger, the smaller the geographic area. By defining local labor markets at the state level (as opposed to cities), we should therefore find very small or insignificant displacement effects.

\section{Data and Empirical Methodologies}

\subsection{Data}

The present study exploits recent annual data from 2000 to 2013. We use two sources of data: the Public Use Microdata Samples of the Decennial Census for the year 2000 and the 
American Community Survey for the subsequent years. The 2000 census forms a 5 percent random sample of the population, while each ACS forms a 1 percent random sample of the population. ${ }^{13}$

\subsubsection{Sample selection and state-skill cell construction}

We investigate the effect of immigration on labor market outcomes of native workers within a given U.S. State, year and skill-cell. The analysis is restricted to men aged 18-64, who do not live in group quarters (e.g., correctional facilities, military barracks, etc.) and who are not enrolled in school. Consistently with the U.S. literature, we define an immigrant as someone who is either a non-citizen or a naturalized U.S. citizen. All other individuals are classified as natives. The sample selection is fully consistent with Borjas, (2014, Chapters 4 and 5) as well as Ottaviano and Peri (2012)..$^{14}$

We exploit the geographical dimension of our data by using U.S. States. To define local labor markets, we use the 50 U.S. States (from Alabama to Wyoming according to the statefip classification) and the District of Columbia. For each local labor market, we classify workers into skill groups. As in Borjas (2003) or Ottaviano and Peri (2012), skill groups are defined in terms of both educational attainment and years of labor market experience.

We classify individuals into four distinct education groups (again as Borjas (2003) or Ottaviano and Peri (2012)). There are four education groups: high school dropouts (with less than 12 years of completed schooling), high school graduates (with exactly 12 years of schooling), some college education (with between 13 and 15 years of schooling) and college graduates (with at least 16 years of schooling). Since individuals with similar education but different work experience tend to be imperfect substitutes in production (Card, 2001; Borjas, 2003), we decompose each educational group into eight experience groups of five years interval. We follow Borjas (2003); Ottaviano and Peri (2012) and Borjas (2003); Ottaviano and Peri (2012) and assume that the age of entry into the labor market is 17 for high school dropouts, 19 for high school graduates, 21 for individuals with some college, and 23 for college graduates; we then

\footnotetext{
${ }^{13}$ These are extremely widely used data. See for example Borjas (2014); Peri and Sparber (2011b); Smith (2012).

${ }^{14}$ We build our sample using the do-files available from George Borjas' website at http://www.hks.harvard. edu/fs/gborjas/IEPage.html.
} 
calculate years of experience accordingly. ${ }^{15}$ The analysis is restricted to individuals who have between 1 and 40 years of experience. Thus we build eight experience groups: from 1 to 5 years, 6 to 10 years, etc., up to 36 to 40 years.

\subsubsection{Weekly and hourly earnings}

We use both weekly and hourly earnings to capture natives' wages at the state-skill cell level. All earnings are deflated to real 1999 dollars - we convert dollar amounts to 1999 dollars by using the Consumer Price Index adjustment factors provided on the IPUMS website.

To compute average wages, we exclude workers who are self-employed and who do not report positive wages or salary incomes. We also exclude workers who do not have positive weeks or hours worked. In the 2008-2013 ACS, weeks worked are reported as a categorical variable. For these years, we thus follow Borjas (2014) and impute weeks worked for each worker as follows: 7.4 weeks for 13 weeks or less, 21.3 for 14-26 weeks, 33.1 for 27-39 weeks, 42.4 for 40-47 weeks, 48.2 for 48-49 weeks, and 51.9 for 50-52 weeks. These imputed values are moreover similar to the mean values of weeks worked in the relevant category of the 20012007 ACS.

Weekly earnings are defined for each worker by the ratio of annual earnings to weeks worked. Similarly, hourly earnings are constructed by dividing annual earnings and the number of hours worked per year (this number is given by the product of weeks worked and usual number of hours worked per week). In order to compute average wages per state-skill cell, we use individual weights to ensure the representativity of our sample.

The average log (weekly or hourly) earnings for a particular state-education-experience cell is defined as the mean of log (weekly or hourly) earnings.

\subsubsection{Employment rates}

We use employment rates to capture the employment opportunities of natives - this strategy follows studies by Card (2001); Angrist and Kugler (2003); Glitz (2012); Smith (2012) on the (wage and employment) impact of immigration and of Neumark and Wascher (1992); Deere,

\footnotetext{
${ }^{15}$ The classification by experience group may be inaccurate if, for instance, employers evaluate the experience of immigrants differently from that of natives. In this regard, Borjas (2003) finds that correcting for this potential measurement problem does not really affect the measured wage impact of immigration.
} 
Murphy, and Welch (1995); Thompson (2009) on the (employment) impact of the minimum wage. For each state-skill cell, we compute the log employment rate to labor force and the log employment rate to population. ${ }^{16}$ Moreover, we use employment rates to adjust for the size of the native workforce and of the native population. Note that the two employment rates can be combined to infer the participation rate of natives.

We compute the employment rate to labor force and to population by using information on employment status - the three main categories are "employed", "unemployed", and "not in the labor force". We use individual weights to compute them.

\subsubsection{Internal migration rates}

The ACS contains information not only on individuals' state of residence at the time of the survey, but also on the state of residence one year prior to the survey. We use this information to measure the out- and net-migration rates of native workers for each state-skill cell at time $t$. In order to measure the out- and net-migration rates of natives, we follow the definitions by Borjas $(2006,2014)$ :

- A native is an out-migrant from his/her "original" state of residence (that is, the state of residence one year prior to the survey) if s/he lives in a different state by the time of the survey.

- A native is an in-migrant of his/her current state of residence if $\mathrm{s} /$ he lived in a different state one year prior to the survey.

In line with Borjas $(2006,2014)$, we then compute for each state-skill cell the out-migration rate of natives by dividing the total number of out-migrants by the total number of natives in the "original" state one year before the survey. We also define the in-migration rate as the ratio between the total number of in-migrants and the total number of natives in the current state of residence one year prior to the survey. The net-migration rate of natives relies on Borjas (2006) and is simply the difference between the out-migration rate of natives and the in-migration rate of natives.

\footnotetext{
${ }^{16} \mathrm{We}$ take the log of both employment rates to facilitate the interpretation of the estimated coefficient.
} 


\subsubsection{Immigrant shares}

The immigrant supply shock experienced in a particular skill-cell $i$ in state $s$ at year $t$ is measured by $p_{i s t}$, the number of foreign-born individuals in the total workforce:

$$
p_{i s t}=M_{i s t} /\left(N_{i s t}+M_{i s t}\right)
$$

As in Borjas (2003), $N_{i s t}$ and $M_{i s t}$ give the respective number of natives and immigrants who are in the labor force (employed or unemployed) in a particular state-skill cell. This measure has been used in multiple studies to capture the labor supply shocks induced by immigration - see, e.g., Aydemir and Borjas (2007); Borjas, Grogger, and Hanson (2010); Cortes (2008); Bratsberg, Raaum, Røed, and Schøne (2014). ${ }^{17}$ Over the period we cover, the share of male immigrants in the labor force increased from $14.0 \%$ in 2000 to $18.9 \%$ in 2013 . However, this immigration supply shift did not affect all skill groups and U.S. States equally.

Appendix-Table 11 reports the average share of immigrants in the male labor force across U.S. States over our period of interest (2000-2013). Table 11 does not contradict the global picture that "immigrants in the United States cluster in a small number of geographic areas" (Borjas (2006), p. 221). The share of male immigrants is higher than 20 percent in seven states (Arizona, Florida, Illinois, Nevada, New Jersey, New York and Texas) and lower than 5 percent in eleven states (Alabama, Louisiana, Mississippi, Missouri, Montana, North Dakota, Ohio, South Dakota, Vermont, West Virginia and Wyoming).

Appendix-Table 12 provides the share of male immigrants in the labor force across skill groups in 2000 and 2013 for high, medium and low minimum wage states (the definition of these three groups of U.S. States are based on their minimum wage level - see Figure 3 below). As one can see in Table 12, the immigrant share has increased for all education-experience groups in all three groups of U.S. States. Table 12 is also consistent with Borjas (2014); Ottaviano and Peri (2012) who show that immigration to the U.S. has disproportionately increased the supply of high school dropouts and college graduates.

\footnotetext{
${ }^{17}$ Our empirical results are robust to the use of the proportion of total work hours supplied by foreign-born workers as an alternative measure for immigrant penetration at the state-skill cell level (Borjas, 2014). This alternative measure for the immigrant supply shock is $p_{i s t}^{h h}=h h_{i s t}^{i m m} /\left(h h_{i s t}^{n a t}+h h_{i s t}^{i m m}\right)$, where $h h_{i s t}^{n a t}$ and $h h_{i s t}^{i m m}$ give the respective number of hours worked by natives and immigrants in a particular state-skill cell. The results are available upon request.
} 
Figure 2: Number of Years Over Which SMW>FMW (2000-2013)

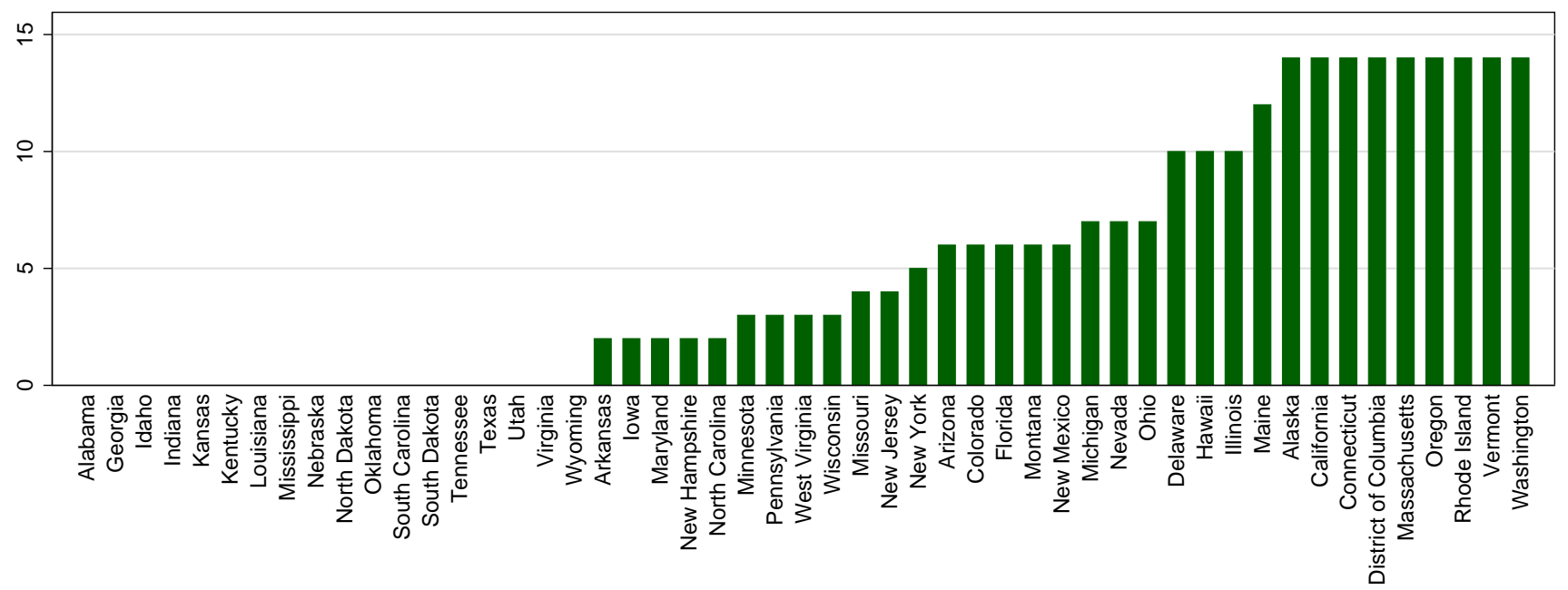

\subsubsection{U.S. States and federal minimum wages}

The United States has the particularity to have state-specific minimum wages (SMW) coexisting with a federal minimum wage (FMW). A state may decide to set a minimum wage higher than the FMW, in which case the SMW applies. Alternatively, some states may have a minimum wage lower than the FMW. In this latter case, the FMW is binding and the state's effective minimum wage (EMW) is equal to the FMW. Hence:

$$
E M W_{s t}=\operatorname{Max}\left\{S M W_{t}, F M W_{t}\right\} .
$$

This results in a non-linearity in the level of minimum wages across U.S. States which we will exploit for identification. ${ }^{18}$

As explained by Baskaya and Rubinstein (2012), a rise in the FMW has a differential effect on a state's EMW. If the federal minimum is legally binding, an increase in the FMW has a direct effect on a state's EMW. However, if the old and new federal minima are not binding, a

\footnotetext{
${ }^{18}$ In doing so, we follow the literature on the wage and employment impact of the minimum wage (Neumark and Wascher, 1992; Card, 1992; Card and Krueger, 1995; Neumark and Wascher, 2006; Orrenius and Zavodny, 2008).
} 
change in the FMW does not affect the EMW. In this regard, Baskaya and Rubinstein (2012) exploit the presumably exogenous source of variation provided by federal wage adjustments to identify the impact of the minimum wage on employment across U.S. States. ${ }^{19}$ Over our period of interest (2000-2013), the FMW rose by 40.8 percent, increasing from $\$ 5.15$ to $\$ 5.85$ in July 2007, reaching $\$ 6.55$ in July 2008 and $\$ 7.25$ in July 2009. Combined with the fact that over our 14-year period the federal minimum wage has been binding in 18 states (see Figure 2 which reports the number of years over which the SMW was higher than the FMW), the changes in federal standards indeed provide a source of external variation for our investigations. ${ }^{20}$ The decision to increase the federal minimum wage floor was taken on January 10, 2007 after the election of a majority of democrats in the Senate and the House of Representatives on January 3,2007 . The minimum wage act of 2007 was devoted to increase the federal minimum wage by $\$ 0.7$ per hour during three successive years.

All minimum wage data used in this study are directly taken from the U.S. Department of Labor. ${ }^{21}$ The states of Alabama, Louisiana Mississippi, South Carolina and Tennessee do not have state minimum wage laws. The effective minimum wage in these states is thus equal to the federal one. We follow Orrenius and Zavodny (2008) in that we do not account for subminimum wages which apply to young workers (under 20 years of age), or to specific occupations, industries (such as serving occupations), or cities. ${ }^{22}$ As for wages, we deflate the effective minimum wage to 1999 dollars by using the Consumer Price Index adjustment factors provided by IPUMS. By definition, the $E M W_{s t}$ is equal to or higher than the $F M W_{t}$, ranging from 4.14 to 6.64 with a mean value of 5.16 .

Figure 3 graphs the evolution of the effective minimum wage for the three groups of states based on Figure 2: the "high minimum wage" group which has an EMW always higher than the FMW $(N=9)$, the "low minimum wage" group which is composed of states where the federal minimum wage is binding $(N=18)$ and the "medium minimum wage" group where the federal minimum wage is binding only part of the time $(N=24) .{ }^{23}$ Figure 3 shows that the

\footnotetext{
${ }^{19}$ The assumption that federal minimum standards is exogenous to state-level economic conditions is also made in Card (1992).

${ }^{20}$ Several factors can explain cross-state disparities in their propensity to be restricted by federal wage floors, such as standards of living and political preferences (Baskaya and Rubinstein, 2012).

${ }^{21}$ See http://www.dol.gov/whd/state/stateMinWageHis.htm.

${ }^{22}$ However, in unreported regressions, we show that our results are unaffected by excluding all workers below age 20 and by excluding waiters and waitresses.

${ }^{23}$ The low minimum wage group thus regroups the states of Alabama, Georgia, Idaho, Indiana, Kansas, Ken-
} 
real effective minimum wage was constant over the period at around $\$ 6$ for the high minimum wage group. The successive increases in the federal minimum wage (recorded in our data in 2008, 2009 and 2010) only affected the low and medium minimum wage states, with a direct impact for the states where the federal minimum wage is binding (i.e., the 18 states of the "low minimum wage group"). In the empirical analysis, we use the differential effects induced by the federal minimum wage adjustments across U.S. States to identify how the minimum wage affects the labor market effects of immigration, and more specifically, by (i) endogenizing states' effective minimum wages (Section 4.3) and (ii) implementing a difference-in-differences approach, comparing the "treated group" of low minimum wage states to the "control group" of high minimum wage states (Section 6.1).

Our empirical analysis mostly focuses on all education-experience groups since minimum wages, and their variations, affect the wage distribution in all skill groups. First, as shown in appendix-Table 13, the share of male native workers paid at the minimum wage is not-null for all skill groups, years, and states. ${ }^{24}$ Second, appendix-Table 13 shows that each skill group experienced an increase in the share of male native workers paid at the minimum wage from 2005 to 2010. The rises in the federal minimum wage by 40.8 percent over that period has therefore affected the wage distribution in all skill groups. However, we also implement regressions for the groups of workers for which the prevalence of minimum wages are the largest (i.e., low-educated and low-experienced groups).

Finally, our baseline proxy $E M W_{s t}$, which measures the importance of a state's effective minimum wage, may not fully capture how binding effective minimum wages are. In fact, similar minimum wages across states may be more or less binding, depending on the wage distribution of workers. For instance, the effective minimum wage should be more binding in states with low median wages than in states with high median wages. As a robustness check, we therefore

tucky, Louisiana, Mississippi, Nebraska, North Dakota, Oklahoma, South Carolina, South Dakota, Tennessee, Texas, Utah, Virginia and Wyoming. The medium minimum wage group is composed of Arizona, Arkansas, Colorado, Delaware, Florida, Hawaii, Illinois, lowa, Maine, Maryland, Michigan, Minnesota, Missouri, Montana, Nevada, New Hampshire, New Jersey, New Mexico, New York, North Carolina, Ohio, Pennsylvania, West Virginia and Wisconsin. The high minimum wage group regroups the states of Alaska, California, Connecticut, District of Columbia, Massachusetts, Oregon, Rhode Island, Vermont and Washington. In appendix, Table 11 reports the average effective minimum wage in real terms for each state over the 2000-2013 period and the corresponding share of male native workers paid at the minimum wage.

${ }^{24}$ It might be that some workers over-report their usual weekly hours, leading to a downward bias in their imputed hourly wage. 
Figure 3: Effective Minimum Wage Evolution (deflated to 1999 dollars)

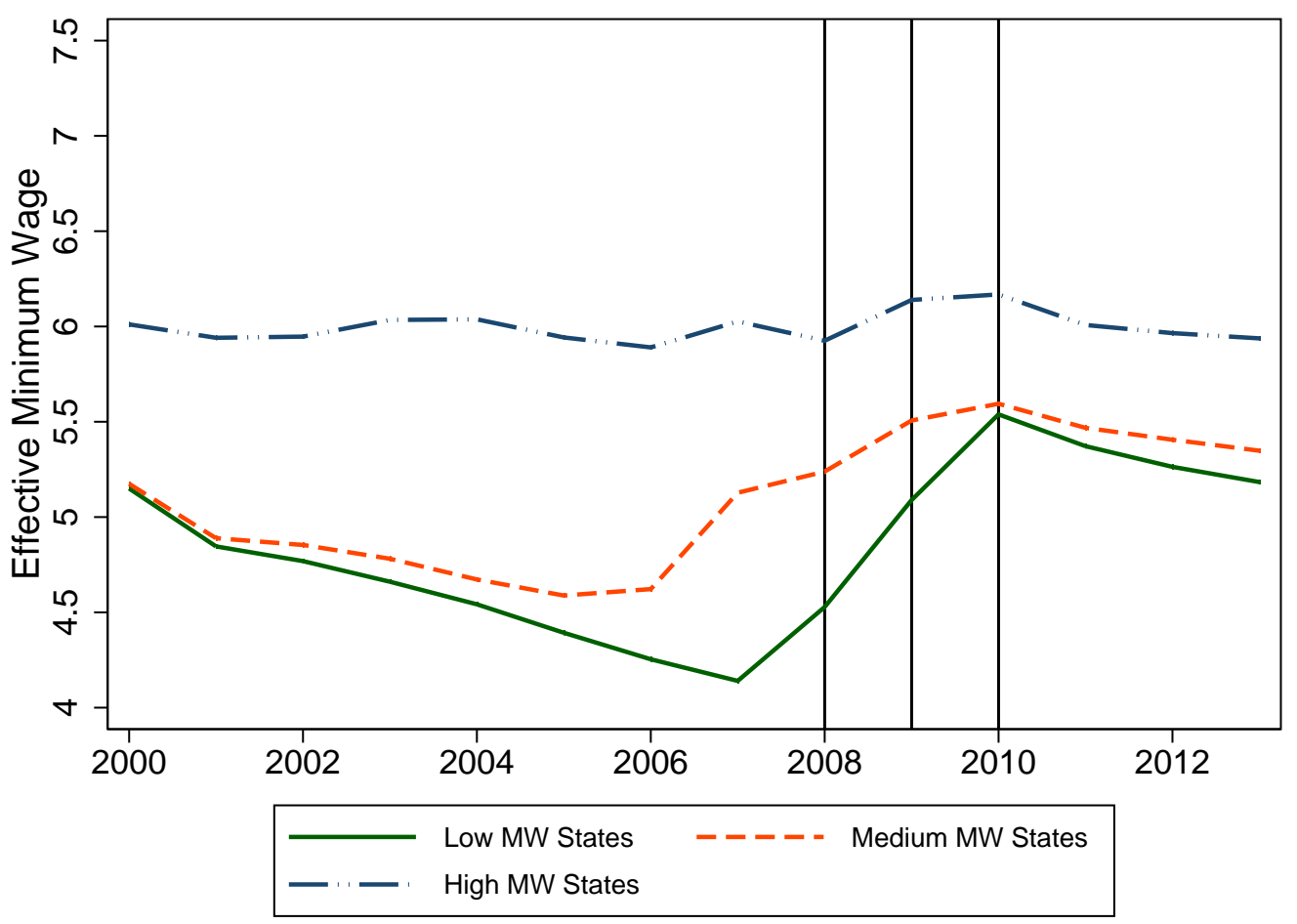


use another proxy for the importance of the state minimum wage borrowed from Lee (1999):

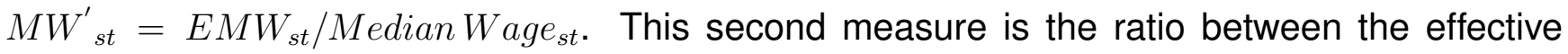
minimum wage and the median wage of native workers who live in state $s$ at time $t$.

\subsection{The Main Empirical Methodology and Identification Issues}

\subsubsection{The state-skill cell approach}

We use the skill-cell methodology to examine the impact of immigration on the employment and wages of native workers. We estimate the following model:

$$
y_{i s t}=\beta_{0}+\beta_{1}\left(p_{i s t}\right)+\beta_{2}\left(p_{i s t} \times M W_{s t}\right)+\delta_{i}+\delta_{s}+\delta_{t}+\delta_{i} \times \delta_{s}+\delta_{i} \times \delta_{t}+\delta_{s} \times \delta_{t}+\xi_{i s t},
$$

where $y_{i s t}$ is the labor market outcome of natives with skill level $i$ who live in state $s$ at time $t$. We use four dependent variables: the mean log weekly wage, the mean log hourly wage and the log of the employment rate as share of population and as share of the labor force, respectively. We introduce immigration as the share of immigrants in the workforce in a particular education-experience-state group, denoted $p_{i s t}$. Our main variable of interest is the interaction term between $p_{i s t}$ and $M W_{s t}$; this interaction term allows us to analyze the non-linearity of the labor market effects of immigration with respect to the minimum wage and estimate the protective effect of the minimum wage.

We include a set of education-experience fixed effects $\delta_{i}$, state effects $\delta_{s}$ and year effects $\delta_{t}$. They control for differences in labor market outcomes across skill groups, states, and over time. In addition, we interact these terms to control for the possibility that the impact of skills (i.e., education and experience) may vary across states or over time. More specifically, the inclusion of state-skill fixed effects allows us to control for unobserved, time-invariant productive characteristics which are state-skill specific. Our identification strategy, therefore, allows us to identify the impact of immigration on wages and employment from changes within stateskill cells over time. Finally, the state-year fixed effects $\delta_{s t}$ control for any unobserved local productivity and demand shocks that should simultaneously affect labor market outcomes and immigration at the state level, as well as the state's effective minimum wage. In the empirical 
analysis, we also cluster our standard errors by state-skill cell to deal with concerns about serial correlation.

\subsubsection{Endogeneity of the immigrant share}

As is well known from the literature, simple OLS estimations tend to underestimate the labor market effects of immigration due to the endogeneity of immigration to wages and employment conditions. This implies that the coefficient $\beta_{1}$ is very likely to be upward biased since immigrants are attracted mostly to places where wages and employment are high (Borjas, 2003; Glitz, 2012; Ottaviano and Peri, 2012; Brücker, Hauptmann, Jahn, and Upward, 2014). To address this issue, we follow the existing literature in using an instrumental variable approach. Specifically, we use an instrument based on past immigration patterns. This approach has been pioneered by Altonji and Card (1991) and then used in several other studies such as Card (2001); Cortes (2008); Peri (2012); Borjas (2014), and indeed networks have been shown to be a strong determinant of migration and location decisions (Munshi (2003); McKenzie and Rapoport (2010) in the case of Mexico to U.S. migration). As in Borjas (2014), we will use to build our instrument the 1980 distribution of immigrants from a given country for a given skill group across U.S. States to allocate the new waves of immigrants from that skill-country group across states. We follow Peri (2012) and use ten nationality groups: Mexico, rest of Latin America, Canada-Australia-New Zealand, Western Europe, Eastern Europe and Russia, China, India, rest of Asia, Africa, and others (mostly Cuba and West Indies). Our instrument $\hat{p}_{i s t}$ is thus computed as follows:

$$
\hat{p}_{i s t}=\hat{M}_{i s t} /\left(\hat{N}_{i s t}+\hat{M}_{i s t}\right)
$$

where,

$$
\hat{M}_{i s t}=\sum_{c} \frac{M_{i s}^{c}(1980)}{M_{i}^{c}(1980)} \times M_{i}^{c}(t)
$$

and, 


$$
\hat{N}_{i s t}=\frac{N_{i s}(1980)}{N_{i}(1980)} \times N_{i}(t)
$$

We also predict the number of natives since the actual number of natives in a state-skill group is not exogenous to current economic impact of immigration - natives may internalize the labor market effects of immigration and respond accordingly (see Peri and Sparber (2011a) for a general discussion on this issue). However, and following Borjas (2014, chapter 4), we will show that our IV estimates are robust to an alternative instrument where we do not instrument the current number of natives in the workforce by their past spatial distribution.

One cannot still be sure that past immigrant settlement patterns are fully exogenous to current demand shocks. It might be that past immigrants chose places following specific labor demand shocks and any long-run persistence of these shocks would invalidate our instrument. As in Peri and Sparber (2009); Peri (2012), we thus use an alternative instrument combining past distribution of immigrants with the geographical distance between each state's capital and each country of origin's capital. ${ }^{25}$ This type of instrument is expected to be more exogenous to state-skill economic conditions as it includes a geographical dimension. The distance is indeed uncorrelated with past and current economic conditions at the state-skill level and, moreover, distance should affect the current locational choices of migrants across states. We thus define our alternative instrument as $\hat{p}_{i s t}^{\text {dist }}=\hat{M}_{i s t}^{\text {dist }} /\left(\hat{N}_{i s t}+\hat{M}_{i s t}^{\text {dist }}\right)$ where,

$$
\hat{M}_{i s t}^{\text {dist }}=\sum_{c}\left(\left(\frac{M_{i s}^{c}(1980)}{M_{i}^{c}(1980)} \cdot \log \left(\text { dist }_{s c}\right)\right) \times M_{i}^{c}(t)\right)
$$

The interaction with the log distance captures the fact that network effects created by the presence of earlier migrants in a state should be stronger when dist ${ }_{s c}$ (i.e., the distance between that state and the origin country) is relatively high.

An additional source of bias could be due to the structure of our sample size to compute the

\footnotetext{
${ }^{25}$ For Mexico, China and India, we use the country's capital, respectively Mexico, Beijing and New Delhi. For the other nationality groups, we use Bogota as capital for the rest of Latin America, Ottawa for Canada-Australia-New Zealand, Paris for Western Europe, Moscow for Eastern Europe and Russia, Manila for the rest of Asia (as most immigrants from this group come from the Philippines and Vietnam), Lagos for Africa, and La Havana for the last group which mainly includes immigrants from Cuba and West Indies.
} 
immigrant share $p_{i s t}$. A small sample size per cell may induce an attenuation bias, leading the estimated impact of immigration to converge toward zero (Aydemir and Borjas, 2011). Thus, we construct seven time periods by pooling data for the years 2000, 2001/2002/2003, 2004/2005, 2006/2007, 2008/2009, 2010/2011, 2012/2013. ${ }^{26}$ We then divide our (new) sample for each of the seven time-periods into state-skill cells. As discussed above, we use four education categories and eight experience categories defined by five-year intervals from 1 to 40 years of experience. This strategy increases the number of observations per skill-cell, reducing potential attenuation bias.

Even after instrumenting and correcting for attenuation bias, there could still be an upward bias in the estimation of the immigration impact due to the fact that natives may react to immigration by moving to other states, which creates a diffusion effect of the impact of immigration across the entire economy (Borjas, 2006; Monras, 2015). While we are unable to correct for this additional potential source of upward bias, we are able to estimate the extent of "native flight". In particular, in the Section B of the appendix, we show that immigration-induced changes in labor shocks at the state-skill level have very small effects on the reallocation of natives across U.S. States. As a result, the "native flight" is very unlikely to bias our estimated effects of immigration on wages and employment.

\subsubsection{Endogeneity of minimum wages}

It could well be that $\hat{\beta}_{2}$ is biased due to the endogenous determination of state effective minimum wages. On the one hand, Baskaya and Rubinstein (2012) show that the level of state effective minimum wages tend to be procyclical, in which case the OLS estimates of the interaction term $p_{i s t} \times M W_{s t}$ is very likely to be upward biased. For instance, a state-biased productivity shock could affect positively both the effective minimum wage and immigration, leading to an omitted variable bias. On the other hand, the OLS estimated coefficients on $p_{i s t} \times M W_{s t}$ may be downward biased if higher immigration levels due to better employment prospects lead states to increase their wage flexibility by reducing their effective minimum wages. As discussed in 3.2.1, our identification strategy should strongly reduce such bias since we control for state-

\footnotetext{
${ }^{26} 2000$ is the only year for which we have the full census. We merge the remaining years into six two-year period and one three-year period. We chose to group the years 2001, 2002 and 2003 together because these are the ones with the lowest total number of observations.
} 
year factors that may affect states' choices when setting their minimum wages. As a result, any additional bias in the estimate of $\beta_{2}$ should come from endogenous choices that are state-skilltime specific.

In order to recover an unbiased estimate of $\beta_{2}$, we follow the strategy proposed in Baskaya and Rubinstein (2012) which use the federal minimum wage to instrument states' effective minimum wages. In fact, (i) a change in the federal minimum wage tend to be exogenous to local labor market conditions and (ii) has differential effects on the effective minimum wage across states (as explained in Section 3.1.6). ${ }^{27}$ In a second step of our empirical analysis, we therefore implement regressions where we instrument $p_{i s t}$ and $p_{i s t} \times M W_{s t}$ by $\hat{p}_{i s t}$ and $\hat{p}_{i s t} \times F M W_{t}$.

\subsubsection{The endogeneity of immigrant shares to minimum wages}

As discussed in section 2, a simple supply-and-demand framework predicts that the negative immigration impact on the wages and employment of competing natives should be mitigated in labor markets where a high minimum wage prevails. This theoretical insight is tested empirically by estimating $\beta_{2}$, which reflects the protective effect of the minimum wage. An econometric issue that arises is that any changes in minimum wages may be systematically associated with lower or higher immigrant shares (e.g., through in- or out-of-state migration of natives and/or immigrants). The potential endogeneity of immigrant shares to minimum wages would then contaminate our estimate of $\beta_{2}$. Suppose that the labor market outcome of workers living in state $s$ at time $t$ is a function of $p_{s t}, p_{s t} \times M W_{s t}$ and a set of productive characteristics $X_{s t}$ which are assumed to be uncorrelated with the two regressors of interest. We can write:

$$
y_{s t}=\eta_{1} p_{s t}+\eta_{2}\left(p_{s t} \times M W_{s t}\right)+\eta_{3} X_{s t} .
$$

At the mean value of the minimum wage, the wage and employment effects of the immigrant share are given by $\hat{\eta}_{1}+\hat{\eta}_{2} \cdot \overline{M W}_{s t}$. The protective effect of the minimum wage is captured by $\hat{\eta}_{2}$. Assume that the immigrant share at the state level is partly determined by the state effective minimum wage, such that:

\footnotetext{
${ }^{27}$ In an influential study, Card (1992) also takes federal minimum wages as exogenous to state economic conditions and implements a difference-in differences analysis to estimate the impact of the 1990 increase in the federal minimum wage on employment and earnings in New Jersey and Pennsylvania.
} 


$$
p_{s t}=p_{s t}\left(1+\sigma M W_{s t}\right),
$$

where $\sigma$ measures the sensitivity of $p_{s t}$ to $M W_{s t}$. By substituting the immigrant share response in Equation 8 and deriving $y_{s t}$ by $p_{s t}$, we obtain the impact of immigration:

$$
\frac{\delta y_{s t}}{\delta p_{s t}}=\eta_{1}\left(1+\sigma M W_{s t}\right)+\eta_{2}\left(1+\sigma M W_{s t}\right) \cdot M W_{s t} .
$$

By deriving $\delta y_{s t} / \delta p_{s t}$ by $M W_{s t}$, we can show that our estimate of $\eta_{2}$ does not reflect the protective effect of the minimum wage as it captures a mix of parameters:

$$
\hat{\eta}_{2}=\eta_{1} \sigma+\eta_{2}\left(1+2 \cdot \sigma M W_{s t}\right) .
$$

This equation shows that when minimum wages do not affect the immigration supply shock (i.e., $\sigma=0$ ), $\hat{\eta}_{2}=\eta_{2}$ and our estimate of $\beta_{2}$ from our main empirical Equation 3 is not contaminated by the endogeneity of immigrant shares to minimum wages. In that case, our estimates should capture the "true" protective effect of minimum wages. However, if the level of minimum wages affects immigrant shares (i.e., $\sigma \neq 0$ ), Equation 11 indicates that the estimate of $\eta_{2}$ is uninformative about the true protective effect of the minimum wage. This equation also shows that it is not possible to predict the sense of the bias in the estimate $\eta_{2}$ regardless on the sign of $\sigma$.

It is a priori unclear whether immigrants and natives prefer states with high or low minimum wages, as high minimum wages have ambiguous effect on expected wages, as we have seen. The literature for the U.S. has found mixed results on the influence of minimum wages on the location choices of immigrants. Orrenius and Zavodny (2008); Cadena (2014) show that lowskilled immigrants tend to settle in states with low and stagnant minimum wages. In contrast, Boffy-Ramirez (2013); Giulietti (2014) find that immigrants are more likely to settle in states with higher minimum wages. ${ }^{28}$

\footnotetext{
${ }^{28}$ See also Castillo-Freeman and Freeman (1992) who find that higher minimum wages in Puerto Rico have
} 
In any case, as long as minimum wage changes affect our measure of the immigration supply shock, the estimates of $\beta_{2}$ should be biased. We thus examine this precise issue by estimating the impact of the minimum wage on the immigrant share through the following model which relies on Cadena (2014):

$$
p_{s t}=\alpha_{0}+\alpha_{1} M W_{s t}+\alpha_{2} X_{s t}+\delta_{s}+\delta_{t}+\delta_{s} \cdot t+\epsilon_{s t},
$$

where $s$ indexes states and $t$ years. The state's effective minimum wage is measured by $M W_{s t}$. The vector of controls $X_{s t}$ includes the unemployment rate and the log weekly wage of low-skilled and low-experienced men. The empirical model includes state and year fixed effects. The state fixed effects capture any time-invariant factors that affect employment opportunities within each state while the year fixed effects capture any time factors that are common across states, such as the national business cycle. As in Cadena (2014), we include state-specific linear time trends to control for specific trends in state economic conditions that may affect the minimum wage $M W_{s t}$ and immigrant shares $p_{s t}$, such wage and employment growth. Finally, we cluster the standard errors at the state level.

Our estimated results are presented in Table 1. In our baseline regression (column 1), we restrict our attention to men with less than 10 years of work experience and who have less than college education. ${ }^{29}$ In column 2, we use all men with less than college education. In columns 3 and 4, we focus on high school dropouts having between 1 and 10 years of work experience and having between 1 and 40 years of experience. Our results indicate that state effective minimum wage changes have no impact on immigrant shares. The estimated coefficients are always insignificant and equal to zero. We illustrate the conditional relationship between minimum wage changes and immigrant shares from column 1 in Figure $4 .{ }^{30}$ Figure 4 shows that our results are not driven by any outliers and suggests that state minimum wages do not affect labor supply shocks induced by low-skilled immigration. As a result, this lowers concerns that our finding of a stronger immigration impact in low minimum wage states could be due to their greater (or weaker) attractivity for immigrants rather than to the greater flexibility of their labor

caused an outflow of low-skilled workers to the U.S.

${ }^{29}$ As indicated in Table 13, this group is strongly affected by state's effective minimum wages.

${ }^{30}$ The points in the scatter diagram are the residuals from a regression of the state's effective minimum wage and the immigrant share on the set of controls presented in Equation 12. 
Table 1: The Impact of Minimum Wages on the Immigrant Share

\begin{tabular}{|c|c|c|c|c|}
\hline & \multicolumn{2}{|c|}{ Less than College } & \multicolumn{2}{|c|}{ High School Dropouts } \\
\hline & $\operatorname{Exp} \in[1,10]$ & $\operatorname{Exp} \in[1,40]$ & $\operatorname{Exp} \in[1,10]$ & $\operatorname{Exp} \in[1,40]$ \\
\hline Real Minimum Wage & $\begin{array}{c}0.00 \\
(0.12)\end{array}$ & $\begin{array}{l}-0.00 \\
(-0.02)\end{array}$ & $\begin{array}{l}-0.01 \\
(-0.71)\end{array}$ & $\begin{array}{c}0.00 \\
(0.37)\end{array}$ \\
\hline Unemployment Rate & $\begin{array}{l}-0.12^{* * *} \\
(-3.07)\end{array}$ & $\begin{array}{l}-0.08 \\
(-1.23)\end{array}$ & $\begin{array}{l}-0.26^{\star \star *} \\
(-5.17)\end{array}$ & $\begin{array}{c}-0.22^{\star \star \star} \\
(3.81)\end{array}$ \\
\hline Log Weekly Wage & $\begin{array}{c}0.00 \\
(0.06)\end{array}$ & $\begin{array}{l}-0.00 \\
(-0.40)\end{array}$ & $\begin{array}{l}-0.01 \\
(-0.11)\end{array}$ & $\begin{array}{c}-0.01 \\
(-0.96)\end{array}$ \\
\hline State FE & Yes & Yes & Yes & Yes \\
\hline Year FE & Yes & Yes & Yes & Yes \\
\hline State time-trends & Yes & Yes & Yes & Yes \\
\hline Adj. R-squared & 0.51 & 0.26 & 0.48 & 0.13 \\
\hline Observations & 714 & 714 & 714 & 714 \\
\hline
\end{tabular}

Notes. ${ }^{* * *},{ }^{* *},{ }^{*}$ denote statistical significance from zero at the $1 \%, 5 \%, 10 \%$ significance level. All regressions include state fixed effects, year fixed effects and state-specific linear time trends. Standard errors are adjusted for clustering within state cells.

market.

\subsection{Exploiting a Difference-in-Differences Strategy}

As shown in Figure 3, the successive rises in the federal minimum wage in 2008, 2009 and 2010 affected different states differently. We can distinguish between three groups of states: the "low minimum wage" states $(N=18)$, where federal minimum wages have been binding over the whole period; the "high minimum wage" states $(N=9)$ where the effective minimum wages are systematically higher than federal minimums over the period; and an intermediate group $(N=24)$. We take advantage of this specific design to estimate the differential impact of 
Figure 4: Immigrant Share and Minimum Wage across States (2000-2013)

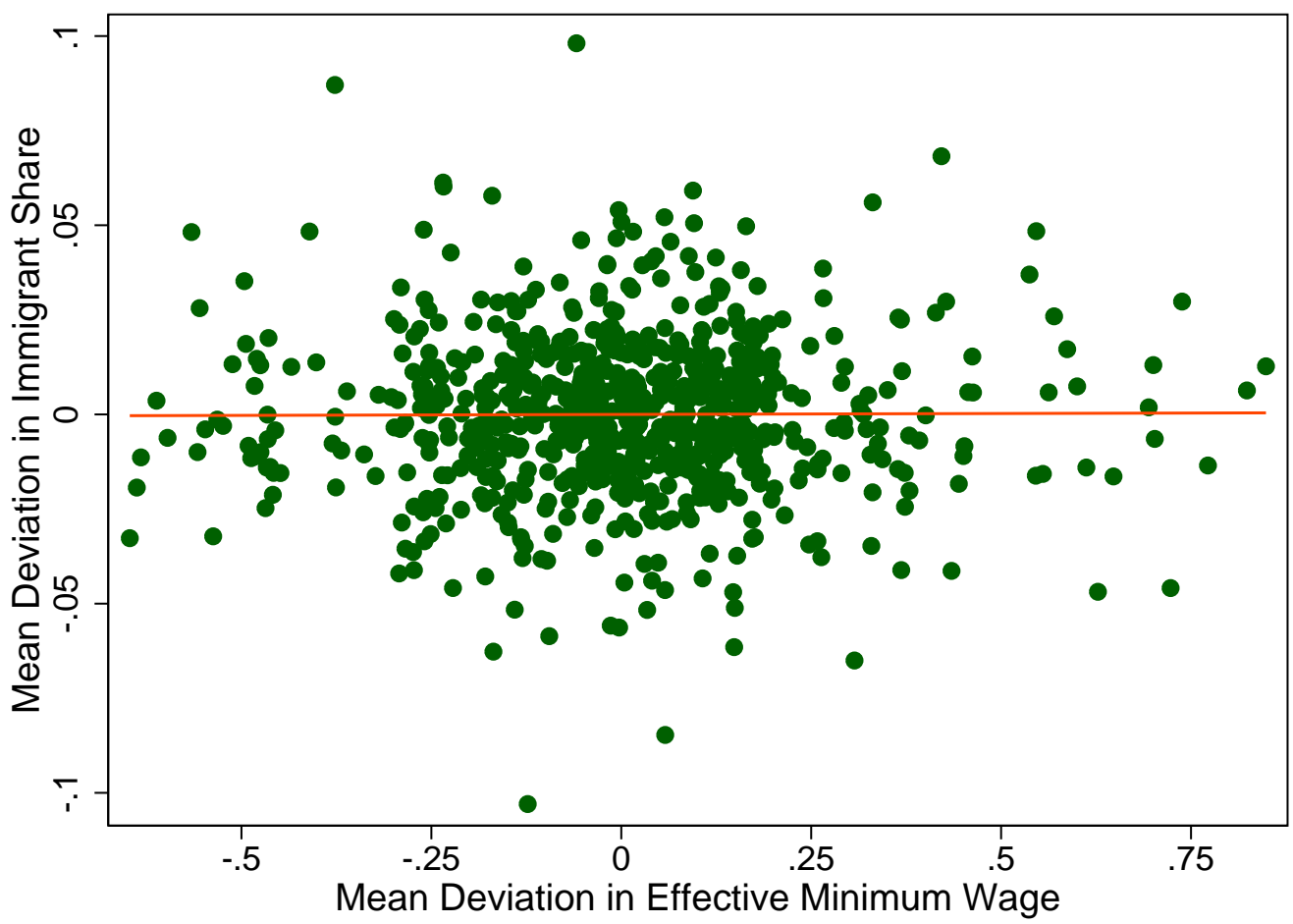

Notes. We focus on male individuals who are not enrolled in school and who are not self-employed with at most a high school education and less than 10 years of work experience. Each point in the scatter represents a state-year cell. For each cell, we take the difference between the effective minimum wage (deflated to 1999 dollars) and its mean over the sample period (horizontal axis). Similarly, we demean the immigrant share (vertical axis). We also remove any year-specific effects that are common to all states from the data and allow time effects to vary by states.

immigration on natives' outcomes over time between the high- and low minimum wage states. We expect the negative effects of immigration to have been more mitigated in low minimum wage states as these are fully affected by the changes in federal minimum wage. Our differencein-differences (DiD) strategy compares the estimated effects of immigration before and after the policy changes in low- $v$. high minimum wage states (that is, in the treated $v$. the control group).

Let us assume that the federal minimum wage increases at time $t$. This rise should mainly affect the states where federal minimums are binding, with no impact on the control group (i.e., where the effective minimum wage does not change). This asymmetric impact of the policy change should lead to differential effects of immigration on the labor market between the treated and the control group. The DiD estimator of the differential labor market impact of immigration 
induced by the policy change at time $t$ can then be defined as:

$$
\mathbb{E}\left[\hat{\beta}_{1}^{P O S T}-\hat{\beta}_{1}^{P R E} \mid X, \text { Treated }=1\right]-\mathbb{E}\left[\hat{\beta}_{1}^{P O S T}-\hat{\beta}_{1}^{P R E} \mid X, \text { Treated }=0\right],
$$

where $\hat{\beta}_{1}$ is the estimated impact of immigration on the labor market outcomes of native workers (see Equation 3 ) before (Pre) and after (Post) the policy change. The dummy variable "Treated" is equal to one if the state belongs to the low minimum wage group and to zero if the state belongs to the high minimum wage group. We exclude the intermediate group of states from the analysis. Given the above, we expect that:

$$
\mathbb{E}\left[\hat{\beta}_{1}^{P O S T}-\hat{\beta}_{1}^{P R E} \mid X, \text { Treated }=1\right]-\mathbb{E}\left[\hat{\beta}_{1}^{P O S T}-\hat{\beta}_{1}^{P R E} \mid X, \text { Treated }=0\right]>0 .
$$

The corresponding DiD regression which allows us to estimate the changes in the protective effect of minimum wages induced by the rise in federal minimum wages can be expressed as:

$$
\begin{aligned}
y_{i s t} & =\lambda_{0}+\lambda_{1} p_{i s t}+\lambda_{2}\left(p_{i s t} \cdot \text { Treated }_{s}\right)+\lambda_{3}\left(p_{i s t} \cdot d t_{2008}\right)+\lambda_{4}\left(p_{i s t} \cdot d t_{2009}\right)+\lambda_{5}\left(p_{i s t} \cdot d t_{2010}\right) \\
& +\lambda_{6}\left(p_{\text {ist }} \cdot \text { Treated }_{s} \cdot d t_{2008}\right)+\lambda_{7}\left(p_{\text {ist }} \cdot \text { Treated }_{s} \cdot d t_{2009}\right)+\lambda_{8}\left(p_{\text {ist }} \cdot \text { Treated }_{s} \cdot d t_{2010}\right) \\
& +\delta_{i}+\delta_{s}+\delta_{t}+\delta_{i} \times \delta_{s}+\delta_{i} \times \delta_{t}+\delta_{s} \times \delta_{t}+\mu_{i s t},
\end{aligned}
$$

where $i$ indexes skill groups, $s$ indexes states and $t$ indexes years; as can be seen we include the same set of fixed effects as in Equation 3. The error term is denoted $\mu_{i s t}$. The dummy variables $d t_{2008}, d t_{2009}$ and $d t_{2010}$ are respectively equal to one when $t=2008, t=2009$, and $t>2010$ and zero otherwise. To allow the labor market effects of immigration to vary over time and across states, we interact $p_{i s t}$ with the treatment and time dummies. The interaction term $p_{i s t}$. Treated $_{s}$ captures systematic differences in the immigration impact between the treatment and control groups prior to the policy change. The interaction terms between $p_{i s t}$ and time dummies captures factors that would cause yearly changes in the impact of immigration on $y_{\text {ist }}$ even in the absence of the policy change. The key coefficients, $\lambda_{6}, \lambda_{7}$ and $\lambda_{8}$ measure the DiD estimates of the policy interventions on the effects of immigration on $y_{i s t}$ in the treated $v$. the 
Table 2: Average Estimated Effects of $p_{i s t}$ on $y_{i s t}$ before and after the Federal Minimum Wage Increases

\begin{tabular}{|c|c|c|c|c|c|}
\hline \multicolumn{2}{|c|}{ Policy Change } & \multirow{2}{*}{$\begin{array}{c}\begin{array}{c}\text { Before } \\
\text { (a) }\end{array} \\
\begin{array}{c}\lambda_{1}+\lambda_{2} \\
\lambda_{1}\end{array}\end{array}$} & \multirow{2}{*}{$\begin{array}{c}\begin{array}{c}\text { After } \\
\text { (b) }\end{array} \\
\lambda_{1}+\lambda_{2}+\lambda_{3}+\lambda_{6} \\
\lambda_{1}+\lambda_{3}\end{array}$} & \multirow{2}{*}{$\begin{array}{l}\text { First Difference } \\
\qquad \begin{array}{c}\text { (a)-(b) } \\
\lambda_{3}+\lambda_{6} \\
\lambda_{3}\end{array}\end{array}$} & \multirow{2}{*}{$\begin{array}{c}\text { Diff-in-Diff } \\
\text { Estimate } \\
\qquad \lambda_{6}\end{array}$} \\
\hline 2008 & $\begin{array}{l}\text { Treatment } \\
\text { Control }\end{array}$ & & & & \\
\hline \multirow[t]{2}{*}{2009} & Treatment & $\lambda_{1}+\lambda_{2}+\lambda_{3}+\lambda_{6}$ & $\begin{array}{c}\lambda_{1}+\lambda_{2}+\lambda_{3}+\lambda_{4} \\
+\lambda_{6}+\lambda_{7}\end{array}$ & $\lambda_{4}+\lambda_{7}$ & $\lambda_{7}$ \\
\hline & Control & $\lambda_{1}+\lambda_{3}$ & $\lambda_{1}+\lambda_{3}+\lambda_{4}$ & $\lambda_{4}$ & \\
\hline \multirow[t]{2}{*}{2010} & Treatment & $\begin{array}{c}\lambda_{1}+\lambda_{2}+\lambda_{3}+\lambda_{4} \\
+\lambda_{6}+\lambda_{7}\end{array}$ & $\begin{array}{c}\lambda_{1}+\lambda_{2}+\lambda_{3}+\lambda_{4}+\lambda_{5} \\
+\lambda_{6}+\lambda_{7}+\lambda_{8}\end{array}$ & $\lambda_{5}+\lambda_{8}$ & $\lambda_{8}$ \\
\hline & Control & $\lambda_{1}+\lambda_{3}+\lambda_{4}$ & $\lambda_{1}+\lambda_{3}+\lambda_{4}+\lambda_{5}$ & $\lambda_{5}$ & \\
\hline
\end{tabular}

control group. Table 2 provides a correspondence table between the $\lambda s$ in Equation 14 and the impact of $p_{i s t}$ on $y_{i s t}$ before and after the policy change in the treated $\mathrm{v}$. the control group, allowing in fine to recover the $\mathrm{DiD}$ estimates.

The key identification assumption is that changes in the impact of $p_{i s t}$ on $y_{i s t}$ would have been the same for the treatment and the control groups in the absence of the policy changes (the parallel trend assumption). In fact, the DiD estimate is assumed to be an unbiased estimate of the effect of the policy change if, absent the policy change, the effect of $p_{i s t}$ on $y_{\text {ist }}$ would have been the same for treatment and controls. Under that plausible assumption, our identification strategy allows for a causal interpretation of the results. For treated and control groups, Figure 8 of the appendix displays the evolutions of weekly wages, employment rates of natives, as well as the share of immigrants in the labor force for the whole sample of men and the sample of men who have less than 10 years of work experience and less than a college education. Although wages, employment and the immigrant share differ in levels, but not in their trends. In fact, the graphs show that these outcomes vary in the same way over the 2000-2013 period. 
We also provide the evolutions of the relative number of college vs non-college workers over the considered period in Figure 8. This figure shows that the difference in skill composition between the control and treated groups of states did not change between 2003-2013. Taken together, Figures 8 and 9 support the parallel trend assumption.

We instrument the share of immigrants as before and cluster our standard errors at the state level to account for possible serial correlation in labor market outcomes at the state level. The strategy to cluster standard errors on the treatment group level (e.g., at the state level when exploiting state level policy variation) is suggested by Bertrand, Duflo, and Mullainathan (2004); Cameron and Miller (2015). ${ }^{31}$

\section{Main Results}

\subsection{OLS Estimates}

Table 3 reports the estimates for our main coefficients of interest, $\beta_{1}$ and $\beta_{2}$. They respectively measure the effects of the immigrant share and its interaction with the state's effective minimum wage. These coefficients can thus be used to compute the natives' wages and employment elasticities to immigration, as well as to quantify how they respond to a change in effective minimum wages.

In Table 3, Specification 1 (our baseline) considers all men. In specifications 2 and 3, we include women in the sample to compute both the dependent and explanatory variables. Specification 3 restricts the analysis to full-time workers only. Each regression has around 22,848 observations (i.e., 4 education groups, 8 experience groups, 51 states and 14 years of data). As in Borjas (2014), we weight wage regressions by the share of observations used to compute the mean wage per state-skill cell at time $t$. This strategy normalizes the sum of weights to one in each cross-section and, therefore, ensures that each cross-section has the same weight. Similarly, we weight both employment regressions by the number of natives in the labor force per cell divided by the total number of natives in the labor force per year. In all regressions, the standard errors are clustered at the state-skill group level.

\footnotetext{
${ }^{31}$ Our DiD estimates are not sensitive to this choice and are fully robust to alternative estimates which control for within-cluster error correlation at the state-skill level.
} 
Table 3: The OLS Estimated Effects of Immigration on Natives' Wages and Employment

Dependent Variable

Specification

$\begin{array}{ll}\text { 1. Men } & p_{\text {ist }} \\ & p_{\text {ist }} \times M W_{\text {st }}\end{array}$

2. Men and Women $p_{i s t}$

$p_{i s t} \times M W_{s t}$

3. Men and Women $p_{i s t}$ Full-time Only

\begin{tabular}{|c|c|c|c|}
\hline Weekly Wage & Hourly Wage & $\begin{array}{l}\text { Employment to } \\
\text { Labor Force }\end{array}$ & $\begin{array}{c}\text { Employment to } \\
\text { Population }\end{array}$ \\
\hline$-0.34^{\star \star \star}$ & $-0.35^{\star \star \star}$ & $-0.15^{\star \star *}$ & $-0.30^{\star \star * *}$ \\
\hline$(-3.92)$ & $(-4.67)$ & $(-2.94)$ & $(-3.94)$ \\
\hline $0.06^{\star \star \star}$ & $0.06^{\star \star \star}$ & $0.02^{\star \star}$ & 0.02 \\
\hline$(3.81)$ & $(4.49)$ & $(2.34)$ & $(1.47)$ \\
\hline$-0.29^{\star \star \star}$ & $-0.26^{\star \star \star}$ & $-0.17^{\star \star \star}$ & $-0.48^{\star \star \star}$ \\
\hline$(-3.93)$ & $(-3.90)$ & $(-3.59)$ & $(-6.51)$ \\
\hline $0.06^{\star \star *}$ & $0.05^{\star * \star}$ & $0.03^{\star * *}$ & $0.05^{\star \star \star}$ \\
\hline$(4.02)$ & $(4.01)$ & $(3.22)$ & (3.89) \\
\hline$-0.29^{\star \star \star}$ & $-0.26^{\star \star \star}$ & $-0.19^{\star \star}$ & $-0.51^{\star \star \star}$ \\
\hline$(-3.53)$ & $(-3.45)$ & $(-2.25)$ & $(-4.85)$ \\
\hline $0.05^{\star \star *}$ & $0.05^{\star \star *}$ & $0.03^{\star}$ & $0.05^{\star \star \star}$ \\
\hline (3.59) & $(3.49)$ & (1.89) & $(2.83)$ \\
\hline
\end{tabular}

Key. ${ }^{* * *},{ }^{* *},{ }^{*}$ denote statistical significance from zero at the $1 \%, 5 \%, 10 \%$ significance level. T-statistics are indicated in parentheses below the point estimate.

Notes. The regressions in columns 1 and 2 have 22,847 observations, while they have 22,836 observations in columns 3 and 4 . We weight wage regressions by the share of natives used to compute the dependent variable per year. We weight employment regressions by the share of the native labor force for a given year across cells. Standard errors are adjusted for clustering within state-education-experience cells.

In appendix (Section C, Table 15), we test the robustness of our results to alternative specifications, each of them being estimated for the sample of men only and the sample of men and women. In order to partly address potential attenuation bias (as discussed in section 3.2.2), Panel A of Table 15 considers two-year intervals instead of yearly data, leading to seven sub-periods. In the second panel, we add two regressors to our econometric model: the share of native workers paid at the minimum wage and its interaction with the state's effective minimum wage - this controls for changes in the sample composition of native workers covered by the minimum wage at the skill-state level. ${ }^{32}$ Finally, the third panel uses an

\footnotetext{
${ }^{32}$ In unreported regressions, we add the log of population and its interaction with the state's effective minimum
} 
alternative measure to capture the relative importance of the minimum wage introduced by Lee (1999) and defined as the ratio of the effective minimum wage to the state median wage: $M W_{s t}=E M W_{s t} /$ Median Wage s $_{\text {. }}$.

\subsubsection{Wages}

Each specification in Table 3 shows a negative and significant relationship between immigration and the wages of natives at the state-skill cell level. This finding is in line with other studies for the U.S. (Card, 2001; Borjas, 2003, 2014). However, our estimated coefficients on the interaction term indicate that this negative impact is non-linear with respect to the level of the state's minimum wage. For a given state-skill group, higher effective minimum wages lead to weaker detrimental effects of immigration on natives' wages. Similar results are reported in the appendix (Table 15): our results are robust to the alternative sample with seven sub-periods (Panel A), to additional regressors (Panel B) and to the alternative minimum wage measure (Panel C). This first set of results is therefore consistent with testable implication 1 in section 2 above: high minimum wages exert a protective effect on native workers' wages.

Moreover, our estimated coefficients often indicate that immigration has a more detrimental impact on the weekly wage of native workers, implying that immigration tends to reduce the number of hours worked by native workers. As immigration decreases hourly wages, some native workers tend to respond at the intensive margin by reducing their hours of work.

\subsubsection{Employment}

Let us now focus on the extensive margin, i.e. unemployment and inactivity. We investigate this issue in columns 3 and 4 of Tables 3 and 15 (in appendix, Section C).

We find that an immigrant-induced increase in the number of workers in a particular stateskill cell reduces native employment rates in that group. This is consistent with testable implication 2 in section 2 above: at lower wages, the number of native workers decline. Some of them become unemployed, whereas others become inactive. Our baseline estimates in columns 3 and 4 are quantitatively different, implying that immigration has also a negative impact on the wage as additional regressors. Our baseline estimates of $\beta_{1}$ and $\beta_{2}$ are fully robust to this alternative specification. 
participation rate of native men. The share of immigrants thus affects the level of male native unemployment and inactivity. ${ }^{33}$

When including women in the sample, we find stronger differences between the estimates in columns 3 and 4 . In particular, the impact on the employment rate to population is much more detrimental than the impact on the employment rate to labor force. This asymmetric impact of immigration between the overall sample and the sample of men suggests that women's labor supply tends to be more responsive to wage changes than men's labor supply at the extensive margin. Such interpretation is consistent with the fact that a decrease in wages may discourage many women to work in the labor market, encouraging them to move to household production or inactivity. Hence, these results are consistent with our testable implication 3 with the additional insight that the effect of immigration on the choice between unemployment and inactivity is differentiated by gender.

Moreover, we find that the negative employment effect due to immigration tend to be stronger when focusing only on full-time native workers (specification 3). This result may suggest that reservation wages of full-time workers are higher than those of part-time workers, so that the employment of full-time workers is more responsive to wage changes.

We find strong evidence of non-linearity in the employment response to immigration. The negative impact of immigration on the employment rate to labor force of native men is clearly weaker in high minimum wage states. Since the adverse impact on natives' wages is weaker in states with relatively high minimum wages, less native workers leave their jobs. This pattern is also true when we include women in the sample and focus on full-time workers only.

In column 4, the interaction term is less significant when focusing on the men sample, suggesting that the level of the state minimum wage has no impact on the labor force participation rate of all native males. The inclusion of women in the sample turns the interaction term to be strongly significant - i.e., immigration has a lower negative impact on the participation rate of natives in high minimum wage state. The asymmetric impact of the interaction term between the overall sample and the sample of men suggests that the participation rate is more sensitive for native women than for native men.

All these results are robust to the specifications used in the Table 15 in the appendix. ${ }^{34}$

\footnotetext{
${ }^{33}$ Some natives may also move to other states. This issue is investigated in section $\mathrm{B}$.

${ }^{34}$ In column 4, Panel B, the estimated coefficient on the interaction term is not significant for the sample of men. However, by instrumenting the immigrant share, we find strongly significant estimate: the estimated coefficient on
} 


\subsubsection{Quantifying the mean effect of immigration and the role of the minimum wage}

From the estimated coefficients $\hat{\beta}_{1}$ and $\hat{\beta}_{2}$ (which respectively measure the impact of $p_{i s t}$ and $p_{i s t} \times M W_{s t}$ ), we can compute the elasticity to immigration of wages and employment, as well as their sensitivity to minimum wage changes.

In order to compute the elasticity to immigration of wages and employment from our estimates, we need to account for the interaction term $p_{i s t} \times M W_{s t}$. At the mean value of $M W_{s t}$ $\left(\overline{M W}_{s t}=5.16\right)$, the total impact of immigration on native weekly wages is -0.03 (or $-0.34+0.06 \times$ 5.16). ${ }^{35}$ As in Borjas (2003); Aydemir and Borjas (2007), we convert this estimate into an elasticity by multiplying it by $\left(1-p_{i s t}\right)^{2} \cdot{ }^{36}$ By 2013 , the immigrant share in the U.S. labor force was 17.6 percent. We thus have to multiply our coefficients by approximately $(1-0.176)^{2}=0.68$. The wage elasticity for weekly earnings is then -0.02 (or $-0.03 \times 0.68$ ), implying that a 10 percent immigrant-induced increase in the number of workers in a particular state-skill group reduces the mean weekly wage of native workers in that group by 0.2 percent. ${ }^{37}$ Similarly, we can compute the mean effect of immigration on the employment rate of natives. The mean impact of immigration on the employment rate to labor force is -0.05 (or $-0.15+0.02 \times 5.16$ ) - at the mean value $\overline{M W}_{s t}=5.16$, the employment elasticity is therefore -0.03 (or $-0.05 \times 0.68$ ). Phrased differently, an immigrant inflow that increases the number of workers in a state-skill group by 10 percent reduces the employment to labor force rate of natives by about 0.03 percent.

In addition, our estimates indicate that the labor market effects of immigration are heterogeneous, depending on state's effective minimum wage. In fact, the estimated coefficients $\hat{\beta}_{2}$ the interaction term becomes 0.06 and the t-student becomes 3.55 (see Table 17).

${ }^{35}$ The mean value of $M W_{s t}$ turns to 5.18 when we weight U.S. States by the total number of male individuals in the labor force.

${ }^{36}$ By defining $m_{i s t}=M_{i s t} / N_{i s t}$ and $\hat{\beta}$ as the estimated impact of the immigrant share $p_{i s t}$ on natives' outcomes $y_{i s t}$, we have:

$$
\begin{array}{lcl}
\partial \log \left(y_{i s t}\right) / \partial m_{i s t}= & {\left[\partial \log \left(y_{i s t}\right) / \partial p_{i s t}\right]} & \cdot\left[\partial p_{i s t} / \partial m_{i s t}\right] \\
\partial \log \left(y_{i s t}\right) / \partial m_{i s t}= & \hat{\beta} & \cdot \partial\left(M_{i s t} /\left(N_{i s t}+M_{i s t}\right)\right) / \partial\left(M_{i s t} / N_{i s t}\right) \\
\partial \log \left(y_{i s t}\right) / \partial m_{i s t}= & \hat{\beta} & \cdot\left(1-p_{i s t}\right)^{2}
\end{array}
$$

Thus, $\partial \log \left(y_{i s t}\right) / \partial m_{\text {ist }}$ measures the percent change in natives' outcome in response to a one percent immigration-induced increase in the labor supply group $(i, s, t)$.

${ }^{37}$ The mean value for $E M W_{s t} /$ Median Wage $s$ is 0.33 . The (weekly) wage elasticity implied by the estimate for men in panel $\mathrm{C}$ (Table $\mathrm{C}$ ) is then -0.003 . 
Figure 5: The Estimated Effects of Immigration on Wages and Employment of Competing Natives

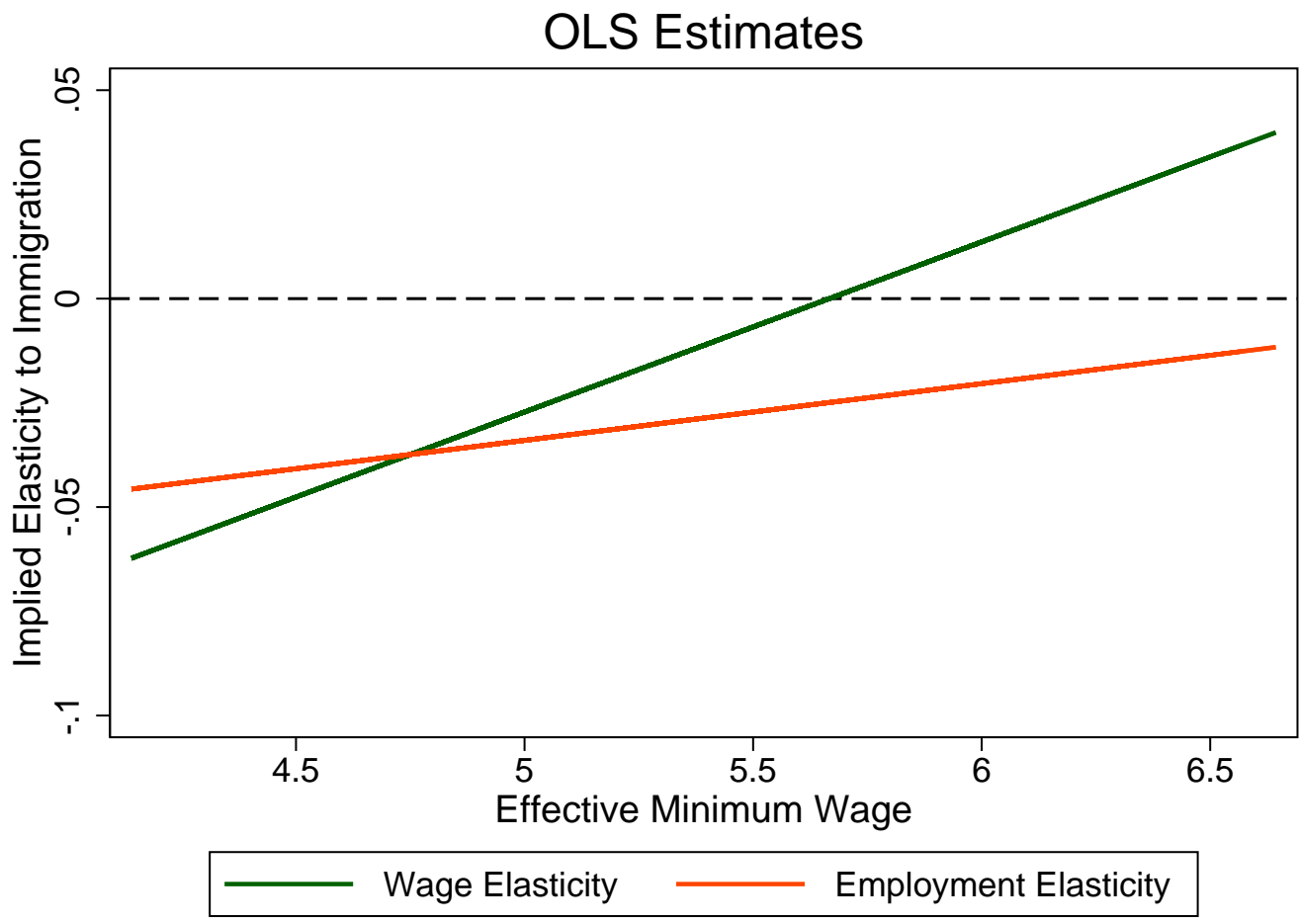


can be interpreted as the change in the wage and employment impact of $p_{i s t}$ from a one unit increase of the state's effective minimum wage - i.e., how a $\$ 1$ increase in the minimum wage affects the impact of $p_{i s t}$ on natives' wages and employment. It is however more relevant to analyze how natives' wage and employment elasticities to immigration respond to minimum wage changes, so that we need to multiply $\hat{\beta}_{2}$ by $(1-0.176)^{2}=0.68$. From the baseline specification of Table 3, we thus find that a $\$ 1$ increase in the minimum wage reduces the wage elasticity by 0.04 unit $(0.06 \times 0.68)$ and the employment elasticity by 0.01 unit $(0.02 \times 0.68)$.

Finally, we can represent graphically the relationship between wage and employment elasticities to immigration and the state's effective minimum wage. In our data, $M W_{s t}$ goes from 4.14 to 6.64. Figure 5 graphs the implied elasticities from our baseline OLS estimates reported in columns 1 and 3 . It shows that, ceteris paribus, the labor market effects of immigration are more detrimental in low minimum wage states. Although the impact of immigration on the employment rate to labor force is always negative, the wage elasticity is positive when $M W_{s t}>5.7$. This positive impact is troubling and may be due to an endogeneity bias or to other factors that may diffuse the impact of immigration across local labor markets. These sources of bias should underestimate the impact of immigration on wages and employment. While the next section tries to address the endogeneity issue in the immigrant share, section B deals with the diffusion of the immigration impact across the entire economy by investigating native responses to immigration to internal (across states' borders) migration.

\subsection{Estimates}

\subsubsection{First-Stage Estimates}

In the first-stage of the IV regressions, we have to implement two regressions since we have two endogenous regressors, i.e. $p_{i s t}$ and $p_{i s t} \times M W_{s t}$. We thus regress both $p_{i s t}$ and $p_{i s t} \times M W_{s t}$ on the instruments (i.e., $\hat{p}_{i s t}$ and $\hat{p}_{i s t} \times M W_{s t}$ ) and a complete set of state-skill fixed effects, statetime fixed effects, skill-time fixed effects. All first-stage estimates indicate a strong positive correlation between the instruments and the endogenous variables. The estimated coefficients on $\hat{p}_{i s t}$ and $\hat{p}_{i s t} \times M W_{s t}$ (as well as the instruments which combine the Card (2001)'s shift-share instrument with geographical distance) are always positive and significant at 1 percent level, except when we use $M W_{s t}=E M W_{s t} /$ Median $W a g e_{s t}$ as an alternative proxy to capture state's 
effective minimum wage. In the last case, the first-stage estimates are significant at 10 percent (at least).

Moreover, the multivariate F-test of excluded instruments is always higher than 100 in most first-stage regressions. The F-test of excluded instruments is between 12 and 100 when we use $\hat{p}_{i s t}^{d i s t}$ and $\hat{p}_{i s t}^{d i s t} \times M W_{s t}$ as instruments, and around 10 when we use the alternative proxy from Lee (1999) to capture the state's effective minimum wage. Most our first-stage regressions thus provide F-tests larger than the lower bound of 10 suggested by the literature on weak instruments. This indicates that our IV estimates are very unlikely to suffer from a weak instrument problem (Stock, Wright, and Yogo, 2002). As a result, $\hat{p}_{i s t}$ and $\hat{p}_{i s t} \times M W_{s t}$ (as well as $\hat{p}_{i s t}^{\text {dist }}$ and $\left.\hat{p}_{i s t}^{\text {dist }} \times M W_{s t}\right)$ are reasonably strong instruments.

\subsubsection{Second-Stage Estimates}

Table 4 reports the estimates of the coefficients $\beta_{1}$ and $\beta_{2}$ using the IV procedure detailed in section 3.2.2, with past immigration patterns as instrument. The first specification uses our baseline sample of men. Specifications 2 and 3 extend the sample to include women, while specification 3 focuses on full-time workers to compute the dependent variables. In appendix, Tables 16 and 17 respectively test the robustness of our estimates to alternative instruments and specifications. More specifically, Panel A of Table 16 uses the same type of instrument as in Borjas (2014, chapter 4) where the number of natives in the workforce is assumed to be exogenous; while Panel B uses an instrument that combines the network justification with geographical distance (as explained in section 3.2.2). Finally, Table 17 uses the same alternative specifications as in Table 15 and focuses on men only. In all tables, we use the same weights as in Table 3 and we cluster our standard errors by state-skill grouping to deal with concerns about serial correlation.

Our IV results reinforce our previous conclusions. ${ }^{38}$ First, immigration has a negative impact on the wages of competing native workers. In particular, according to specification 1, a 10 percent immigration-induced increase in the labor supply reduces weakly earnings by 1 percent.

\footnotetext{
${ }^{38}$ In order to absorb any time-varying heterogeneity across state-education-experience groups, we implement regressions where we include a complete set of education-experience-state fixed effects, education-experience-time fixed effects, education-state-time fixed effects and experience-state-time fixed effects. Our estimated coefficients of $\beta_{1}$ and $\beta_{2}$ have the same sign and are of greater magnitude but they are naturally less significant. The results are available upon request.
} 
Table 4: The IV Estimated Effects of Immigration on Natives' Wages and Employment

Dependent Variable

Specification

\begin{tabular}{|c|c|c|c|c|c|}
\hline \multirow[t]{2}{*}{ 1. Men } & $p_{i s t}$ & $\begin{array}{c}-0.66^{\star \star *} \\
(-4.66)\end{array}$ & $\begin{array}{c}-0.63^{\star \star \star} \\
(-5.20)\end{array}$ & $\begin{array}{c}-0.44^{\star \star *} \\
(-4.64)\end{array}$ & $\begin{array}{c}-0.48^{\star \star *} \\
(-3.63)\end{array}$ \\
\hline & $p_{i s t} \times M W_{s t}$ & $\begin{array}{l}0.10^{\star * *} \\
(4.54)\end{array}$ & $\begin{array}{l}0.10^{\star * *} \\
(5.52)\end{array}$ & $\begin{array}{l}0.06^{\star \star *} \\
(4.61)\end{array}$ & $\begin{array}{c}0.06^{\star \star *} \\
(3.61)\end{array}$ \\
\hline \multirow[t]{2}{*}{ 2. Men and Women } & $p_{i s t}$ & $\begin{array}{c}-0.50^{\star \star \star} \\
(-3.95)\end{array}$ & $\begin{array}{c}-0.42^{\star \star *} \\
(-4.15)\end{array}$ & $\begin{array}{c}-0.42^{\star \star \star} \\
(-4.78)\end{array}$ & $\begin{array}{c}-0.60^{\star \star \star *} \\
(-4.80)\end{array}$ \\
\hline & $p_{i s t} \times M W_{s t}$ & $\begin{array}{c}0.09^{\star \star \star} \\
(5.08)\end{array}$ & $\begin{array}{c}0.08^{\star * *} \\
(5.28)\end{array}$ & $\begin{array}{l}\mathbf{0 . 0 6} \mathbf{6}^{\star * \star} \\
(5.20)\end{array}$ & $\begin{array}{c}0.10^{\star \star *} \\
(5.94)\end{array}$ \\
\hline \multirow[t]{2}{*}{$\begin{array}{l}\text { 3. Men and Women } \\
\text { Full-time Only }\end{array}$} & $p_{i s t}$ & $\begin{array}{l}-0.52^{\star \star \star} \\
(-4.27)\end{array}$ & $\begin{array}{l}-0.44^{\star \star \star} \\
(-4.22)\end{array}$ & $\begin{array}{l}-0.29^{\star *} \\
(-2.35)\end{array}$ & $\begin{array}{l}-0.49^{\star \star *} \\
(-3.20)\end{array}$ \\
\hline & $p_{i s t} \times M W_{s t}$ & $\begin{array}{l}\mathbf{0 . 0 9 * * *} \\
(5.09)\end{array}$ & $\begin{array}{l}\mathbf{0 . 0 8} \mathbf{8}^{\star \star *} \\
(5.07)\end{array}$ & $\begin{array}{l}\mathbf{0 . 0 4}{ }^{\star *} \\
(2.52)\end{array}$ & $\begin{array}{c}0.09 * * * \\
(3.98)\end{array}$ \\
\hline
\end{tabular}

Key. ${ }^{* * *},{ }^{* *},{ }^{*}$ denote statistical significance from zero at the $1 \%, 5 \%, 10 \%$ significance level. T-statistics are indicated in parentheses below the point estimate.

Notes. Each regression has around 22,848 observations (i.e., 4 education groups, 8 experience groups, 51 states and 14 years of data). We weight wage regressions by the share of natives used to compute the dependent variable per year. The employment regressions are weighted by the share of the native labor force for a given year across cells. Standard errors are adjusted for clustering within state-education-experience cells.

This impact is much stronger than our OLS mean impact (-0.02 percent). Correcting for endogeneity thus provides a stronger negative impact on wages. This finding is consistent with the theoretical direction of the bias. Moreover, the mean wage impact of immigration becomes even more negative when using our alternative instrument including geographical distance (Panel B in Table 16): the wage elasticity has almost doubled to be -0.16 . This greater elasticity is consistent with the fact that including distance to compute the instrument provides an additional source of exogenous variation, leading to estimates which are less upward biased.

Second, an increase in the immigrant share tends to depress the employment to labor force rate of equally skilled natives. The implied elasticity from the mean impact of immigration on 
the employment rate to labor force (presented in specification 1) is around -0.09 - this elasticity is much more negative than our baseline OLS estimates $(-0.03)$. Moreover, the effect of immigration on the native employment rate to population becomes now closer to the estimates presented in column 3 , supporting the view that immigration has very little impact on the participation rate of native men.

Third, the prevalence of a minimum wage mitigates the negative effects of immigration on natives' wages and employment at the state-skill group level. All other things equal, the labor market effects of immigration are more detrimental in states with low minimum wages. This is illustrated by Figure 6 which graphs the wage (LHS) and employment (RHS) elasticities to immigration for the range of values of $M W_{s t}$. For each graph, we show the estimated effects from IV regressions where we use the baseline instrument and the alternative instrument including distance. The negative effects of immigration on wages and employment are all the less important as the minimum wage is high. Interestingly, the protective effects induced by state's effective minimum wages are of similar magnitude for natives' wages and employment (particularly when we consider the instrument including geographic distance). Moreover, the IV estimates indicate a stronger protective effect of the minimum wage as compared to our OLS estimates: according to our baseline specification (men), a $\$ 1$ increase in the minimum wage reduces the wage elasticity to immigration by 0.07 unit (vs 0.04 in our baseline OLS estimates) and the employment elasticity to immigration by 0.04 unit (vs 0.01 in our baseline OLS estimates).

\subsection{Instrumenting Effective Minimum Wages}

As explained in Section 3.2.3, the estimated coefficients $\hat{\beta}_{2}$ on $p_{i s t} \times M W_{s t}$ may be biased due to the fact that states' effective minimum wages $M W_{s t}$ are likely endogenous to state labor market conditions (i.e., $M W_{s t}$ may be correlated with unobserved economic changes at the state level). For instance, a positive productivity shock may induce positive changes in effective minimum wages, leading to an upward bias in the estimates of $\beta_{2}$. The bias could be negative if higher immigration lead states to reduce their labor market flexibility (such as their effective minimum wages) to facilitate the absorption of the labor supply shock.

Although the potential bias in the estimates of $\beta_{2}$ is mitigated by the inclusion of state-year fixed effects in each regression (which control for unobserved local demand shocks that may change economic conditions, immigration and minimum wage at the state level), we deal with 
Figure 6: The Estimated Effects of Immigration on Wages and Employment of Competing Natives
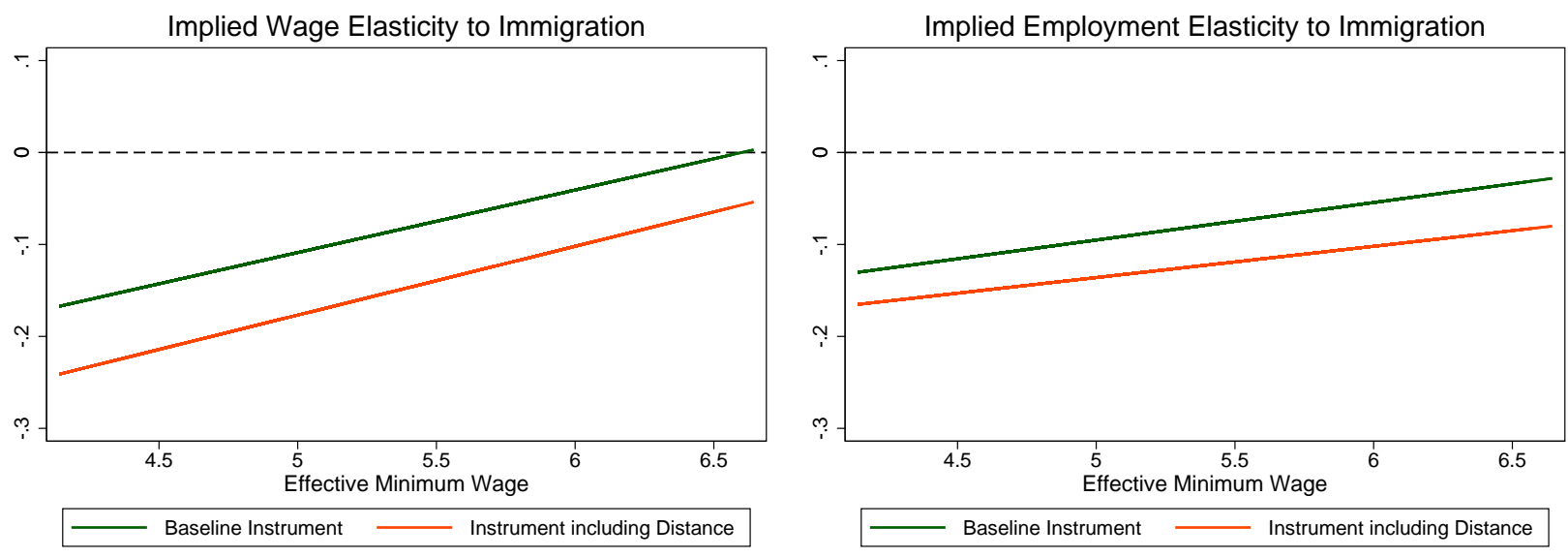

this issue by (i) excluding the high minimum wage states from the sample (i.e., those states having an effective minimum wage structurally higher than federal minimum, as seen in Section 3.1.6) $)^{39}$ and (ii) instrumenting $M W_{s t}$ by the federal minimum wage for the remaining group of states.

In Panel A of Table 5, we exclude from the sample the high minimum wage states and run OLS regressions for the sample of men and the sample of men and women. As shown by Baskaya and Rubinstein (2012), states' effective minimum wages are procyclical only for those states which are not restricted by federal standards. The exclusion of high minimum wage states should therefore strongly reduce the potential bias in the estimations of $\hat{\beta}_{2}$. However, our estimates are perfectly consistent with our previous results: the share of immigrants is negatively correlated with the labor market outcomes of competing native workers, and this negative relationship is weaker when effective minimum wages are high. This result is robust to instrumenting the share of immigrants based on the past distributions of immigrants and natives across states, as shown in Panel B. ${ }^{40}$

\footnotetext{
${ }^{39}$ The high minimum wage group regroups the states of Alaska, California, Connecticut, District of Columbia, Massachusetts, Oregon, Rhode Island, Vermont and Washington.

${ }^{40}$ The first-stage estimates of Table 5 always report high multivariate F-tests of excluded instruments (higher than 100 for the baseline specification when using our baseline instrument, and higher than 50 when using our instrument including distance), suggesting that our IV second-stage estimates are very unlikely to suffer from a
} 
In Panel $\mathrm{C}$, we still exclude the high minimum wage states and instrument both the immigrant share and the states' effective minimum wage by using the federal minimum wage as instrument. ${ }^{41}$ We exploit the successive increases in the federal minimum wage $(2008,2009$ and 2010) since they are presumably exogenous to each individual state economic conditions and have a larger impact in states with lower minimum wage. Our results are consistent with our previous findings. First, the estimated effects indicate that immigration has a negative impact on the wages and employment of native workers with similar skills. Second, this negative relationship is heterogeneous with respect to the level of states' effective minimum wages. In particular, an increase in the states' minimum wage mitigates any wage or employment losses due to immigration, pointing to a protective effect of minimum wages. ${ }^{42}$

We can use the estimates of columns 1 and 3 to compute the wage and employment elasticities to immigration for the sample of men. At the mean value of $M W_{s t}\left(\overline{M W}_{s t}=4.98\right)$, the average wage elasticity to immigration is -0.03 in Panel $A,-0.18$ in Panel $B$, and -0.22 in Panel C; while the average employment elasticity to immigration is -0.001 in Panel $A,-0.12$ in Panel $B$, and -0.14 in Panel C. Although these elasticities are closed to those found in Table 4, the protective effect of minimum wages tends to be stronger when we endogenize states' effective minimum wages (i.e., $\hat{\beta}_{2}$ is higher in Panel $\mathrm{C}$ than in Panels $\mathrm{A}$ and $\mathrm{B}$, especially for the whole sample of men and women). ${ }^{43}$ These results reinforce our previous conclusions: all things equal, the labor market effects of immigration are more detrimental in states with low minimum wages.

weak instrument problem.

${ }^{41} \mathrm{Here}$, the exclusion of high minimum wage states is also motivated by the fact federal minimum wage changes did not affect their effective minimum wages (as shown in Figure 3) - i.e., the power of our instrument is too small when including high minimum wage states.

${ }^{42}$ Appendix-Table 18 reproduces the estimates reported in the Panel $C$ of Table 5, but uses an alternative instrument for the immigrant share to show the robustness of our results. More specifically, Table 18 exploits the instrument combining the past distributions of natives and immigrants with geographical distance.

${ }^{43}$ Notice that any comparison of the estimates in Tables 4 and 5 may be misleading as the sample differs from one table to another. In Table 5, we exclude all the states which always had an effective minimum wage higher than the federal standard over the whole period. 


\section{Heterogeneous Effects across Skill Groups}

This section first provides a placebo test. As shown in Table 13, highly skilled workers are less affected by minimum wage regulations. We thus decompose our sample into a low-wage and a high-wage group, showing that our results are fully driven by the former. Second, we restrict our attention to low-skilled native workers and investigate how minimum wages shape the labor market effects of low-skilled immigration.

\subsection{A Placebo Test on High-skill Workers}

Until now, we have dealt with the overall sample of native workers regardless of their position in the wage distribution. However, as shown in Table 13, the prevalence of a minimum wage should concern low-skill workers. We thus disaggregate our sample into a low-wage and a high-wage group.

In order to define our two subsamples, we compute for each state-skill cell the ratio between the state effective minimum wage and the median wage of the cell, EMW $W_{\text {st }} /$ Median Wage ist $_{\text {. }}$ Over our period of interest, the mean value of this ratio is around 0.36 in the U.S. when considering men only and 0.42 for the whole sample (men and women). We thus keep all cells for which $E M W_{\text {st }} /$ Median Wage ist $>0.36$ or 0.42 to define our low-wage samples for men and men and women. By definition, both subsamples contains 50 percent of our observations and, by definition, each state-skill cell has a minimum wage that represents at least 36 or 42 percent of the median wage of that cell. ${ }^{44}$ We define the high-wage sample by taking the top 25 percent of the sample of men and men and women, i.e. all cells for which $E M W_{s t} / M_{\text {edian Wage }}$ ist $<0.28$ or 0.32 respectively. By design, both subsamples mostly contain college graduate workers with more than 10 years of work experience. ${ }^{45}$

Table 6 shows the OLS and IV results for the two subsamples. While specification 1 focuses on men, specification 2 includes women. In specification 2, we use 0.42 and 0.32 as our threshold values to build both subsamples. We weight wage regressions by the share of natives

\footnotetext{
${ }^{44}$ We obtain similar qualitative results when focusing on the bottom 25 percent of cells to define the low-wage subsamples.

${ }^{45}$ We obtain similar qualitative results when focusing on the top 10 percent of cells to define the high-wage subsamples.
} 
used to compute the dependent variable per year and weight employment regressions by the share of the native labor force for a given year across cells. We also cluster the standard errors at the state-skill level.

Table 6 indicates that our previous results are mainly driven by the low-wage subsample. In fact, the left-panel of these tables shows that immigration has on average a negative impact on wages and employment but that this impact is mitigated by the level of the minimum wage. Moreover, the wage elasticity implied by our IV estimates in the left-panel (column 1, specification 3) is -0.17 indicating that a 10 percent immigrant-induced increase in labor supply reduces weekly earnings by 1.7 percent. This magnitude is stronger than for our overall sample $(-0.1)$ and is consistent with the wage elasticity found in Borjas (2014, chapter 4). On the other hand, the employment elasticity is now equal to -0.16 - this is also higher than our IV estimate derived from the whole sample (-0.09). Finally, we find that the protective effects of the minimum wage (measured by $\hat{\beta}_{2}$ ) are consistent with our previous estimates.

In contrast, the results for the high-wage subsample are mostly insignificant. This result indicates that immigration does not affect the wages and employment of competing native workers for highly educated and experienced groups. This finding of an insensitivity of wages to immigration within the high-skill segment of the labor market is consistent with Orrenius and Zavodny (2007); Steinhardt (2011). They both find that an increase in the fraction of foreign-born workers does not affect the wages of natives working in highly educated occupations. These results may be explained by the fact that the degree of substitution between immigrants and natives tends to vary across skill levels. As explained by Orrenius and Zavodny (2007, p. 759): "substitution is likely to be easier in industries with less skilled workers because employees are more interchangeable and training costs are lower than in industries with skilled workers." Within the highly educated segment of the labor market, Peri and Sparber (2011b) also find that nativeand foreign-born workers tend to be imperfect substitutes. They argue that the lack of interactive and communication skills among immigrants should make it difficult for employers to substitute high-skilled immigrants for high-skilled native workers.

\subsection{Focusing on Low-skill Workers}

As shown in Table 13, the skill groups which are the most affected by the minimum wage are the groups which have less than 10 years of experience and up to high school education. We 
thus go beyond our previous decomposition (section 5.1) and investigate how minimum wages can affect the labor market impact of immigration for those specific skill groups.

We report our estimated results in Table 7. In Panel A, each regression has 2,856 observations (i.e., 4 education groups, one 10-year experience group, 51 states and 14 years of data). As our baseline, specification 1 implements OLS regressions using men only. Specifications 2 and 3 then implement IV regressions using our baseline instrument using the sample of men (specification 1) and the sample of men and women. In Panel B, we still focus on young individuals and restrict the analysis to those having a high school education or less. We thus have a perfectly balanced panel of 1,428 observations (i.e., 2 education groups, one 10-year experience group, 51 states and 14 years of data). For each specification, we include a complete set of education-state fixed effects, education-time fixed effects and state-time fixed effects. We cluster the standard errors at the state-education level.

Our estimates on $p_{i s t}$ and $p_{i s t} \times M W_{s t}$ always have the expected sign, indicating that immigration has a more detrimental impact on the wages and employment of competing native workers in U.S. States where the effective minimum wage is higher than the federal minimum. They are moreover significant when using our instrumentation strategy and robust to the inclusion of women in the sample.

At the mean value of our sample $\left(\overline{M W}_{s t}=5.16\right)$, our IV estimate in specification 2 implies that a 10 percent immigrant-induced increase in the number of low-skilled (male) workers would reduce the weekly wage of low-experienced (male) natives by 3.7 percent. The implied wage elasticity from the estimates of specification 4 is -0.3 . Both wage elasticities are stronger than our baseline wage elasticity of -0.1 and fully consistent with Borjas (2003) which find a wage elasticity between -0.3 and -0.4 for the United States. Moreover, it is not surprising to find a stronger negative impact on the wages of low-skill native workers as the degree of substitution between natives and immigrants within the low-skill segment of the labor market tends to be higher (Card, 2001; Orrenius and Zavodny, 2007; Peri and Sparber, 2011b; Ottaviano and Peri, 2012).

The employment elasticities for the log employment rate to labor force (log employment rate to population) implied by our IV estimate in specifications 2 and 4 are respectively -0.25 $(-0.58)$ and $-0.10(-0.38)$. These elasticities are consistent with Smith (2012) who finds that low-educated immigrants have a strong depressive impact on the employment rate of native 
Figure 7: The Estimated Effects of Immigration on Wages and Employment of Low Skilled Natives

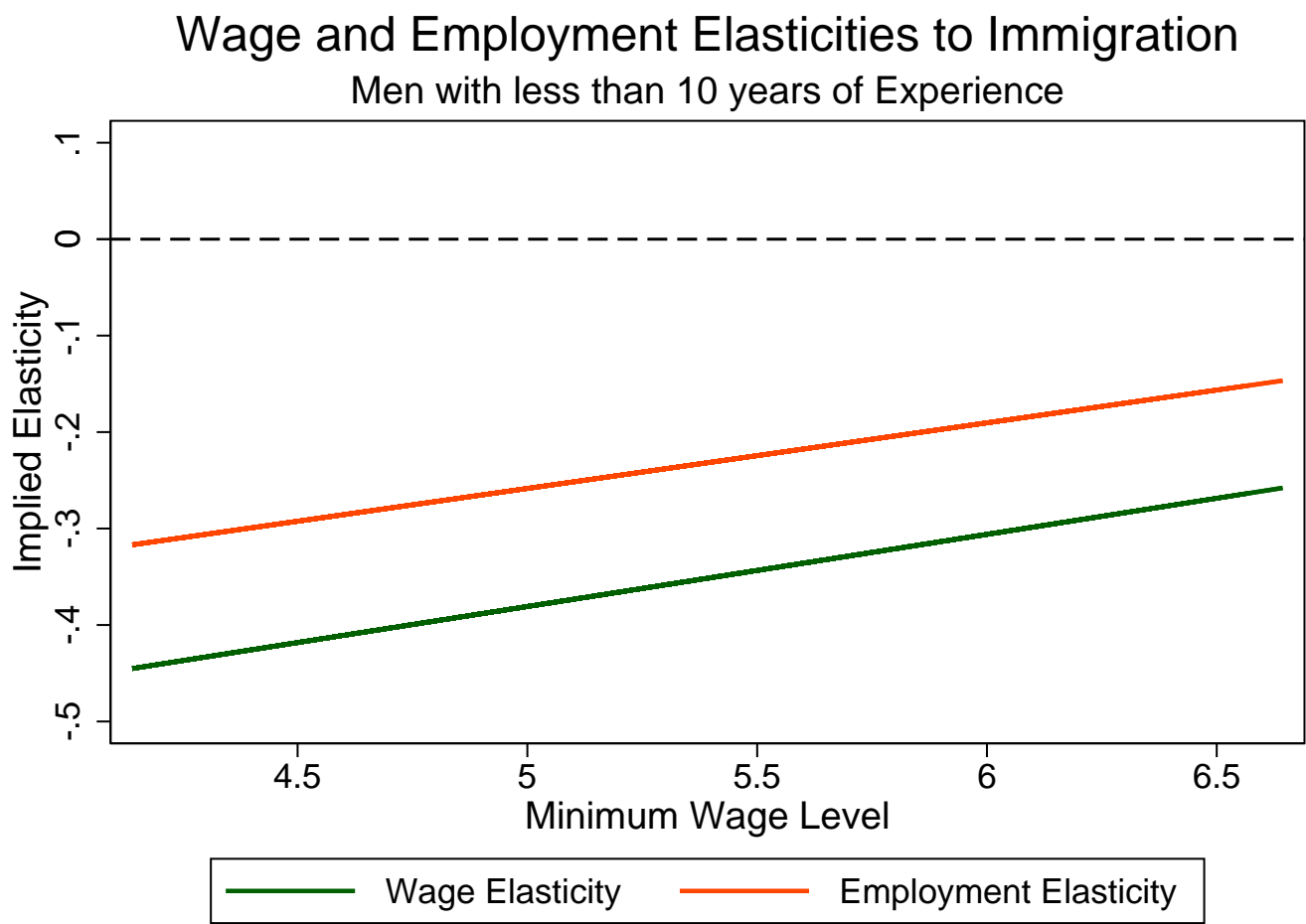

workers below 25 years of age and less than high school education.

Our estimation strategy allows us to go beyond these average effects among low-skilled workers and shows heterogeneous effects with respect to the level of the minimum wage. Ceteris paribus, the negative wage and employment effects induced by immigration are more detrimental in low minimum wage states. Figure 7 illustrates this point graphically by displaying the wage and employment elasticities according to states' effective minimum wages. In the lowest minimum wage states, we find a wage elasticity around -0.46 implying that a 10 percent immigrant-increase in the number of low-skill workers reduces the weekly earnings of low-skill native workers by 4.6 percent. In contrast, the implied wage elasticity is almost two times lower, and equal to -0.26 , in states with the highest minimum wages. Similarly, the employment elasticity goes from -0.15 in high minimum wage states to -0.32 in low minimum wage states. 
In addition, when focusing on the protective effects induced by the minimum wage (see the estimates on the interaction term), Specification 2 of Table 7 indicates that a $\$ 1$ increase in the minimum wage reduces the wage (employment) elasticity to immigration by $0.075(0.07)$. These estimates are slightly higher than our previous IV estimates when considering the whole sample (instead of 0.075 and 0.07 , we found 0.068 and 0.04 ). In specification 4 of Table 7 , which moreover focuses on low-educated workers (with at least a high school education), the estimates on the interaction term reveal stronger protective effects of the minimum wage, around 0.095 (column 1) and 0.075 (column 2). This set of results is consistent with the fact that a change in the minimum wage affects more the workers who are at the lower tail of the wage distribution, i.e. the low-experienced and low-educated ones.

\section{Difference-in-Differences Estimates}

\subsection{OLS and IV Estimates}

We use a complementary methodology based on a difference-in-differences strategy (as discussed in section 3.3). Table 8 provides OLS and IV estimates from Equation 14 for the sample of men. ${ }^{46}$ Appendix-Table 19 reproduces the same table for the sample of men and women. As the level of the federal minimum wage is higher before 2004 than in 2008, we exclude the years 2000-2003 from the analysis. Thus, the three successive increases in the federal standards which occurred in 2008, 2009 and 2010 always led to higher minimums relative to the pre-treatment period. ${ }^{47}$

The three first rows of Tables 8 and 19 report the key coefficients: $\hat{\lambda}_{6}, \hat{\lambda}_{7}$ and $\hat{\lambda}_{8}$. They measure the differential effect of immigration in the low- (treated) v. high- (control) minimum wage states before and after the increases in the federal minimum wage. The estimated coefficients of $\hat{\lambda}_{6}, \hat{\lambda}_{7}$ and $\hat{\lambda}_{8}$ are unbiased under the assumption that time-varying state level variables did not change between the pre- and post-treatment period or that they changed in an identical

\footnotetext{
${ }^{46}$ In our IV regressions for the samples of men and men and women, the first-stage estimates always indicate multivariate F-tests of excluded instruments are between 8 and 23, suggesting that our IV second-stage estimates are unlikely to suffer from a weak instrument problem.

${ }^{47}$ Our DiD estimates are robust to a narrower time-window from 2006 to 2011 . The results are available upon requests.
} 
manner in the control and treated states. They always have the expected sign and are always significant when we account for the endogeneity of the immigrant share. These positive effects indicate that the effects of immigration on wages and employment between the treated and the control groups are weaker after the policy change. This underlines the role played by the minimum wage in shaping the labor market effects of immigration: a rise in the federal minimum wage reduces the negative effects of immigration on the wages and employment of native workers who reside in states where the federal minimum is binding. This result is fully consistent with our previous conclusions: higher minimum wages mitigate wage and employment losses induced by an increase in the number of competing immigrants.

Moreover, the values of $\hat{\lambda}_{6}, \hat{\lambda}_{7}$ and $\hat{\lambda}_{8}$ suggest that the protective effects induced by the federal minimum rises have been increasingly stronger. In particular, the rise in the federal minimum wage in 2010 from $\$ 6.55$ to $\$ 7.25$ has had the most mitigating impact on the labor market effects of immigration. This result is consistent with the effectiveness of the policy: the share of male native workers paid at the minimum wage has strongly increased after the 2010 federal minimum wage increase (from 7.4 percent in 2009 to 10.7 percent in 2010 - see Table 8).

In the bottom part of Table 8, we compute the average elasticity of immigration to wages and employment. On average, we find a wage elasticity of around -0.33 . This is consistent with Borjas (2003) who finds a wage adjustment between -0.3 and -0.4 , confirming that our empirical strategy provides a relevant set of estimates. This average impact is, however, heterogeneous across state groups and over time.

\subsection{Placebo Test}

We now implement a falsification test to provide further evidence of the validity of our DiD strategy and show the robustness of our results. We include pre-treatment periods to our model (see Equation 14) and interact them with the immigrant share and treatment dummy. The idea of this test is to see whether the impact of immigration on labor market outcomes between treatment and control groups before the policy implementation in 2008 is insignificant: such result would support the common trend assumption and reinforce our previous conclusions regarding the protective effect of the minimum wage. We express all interactions terms relative to the year 2007 which is the omitted period. We use the year 2007 as our baseline period 
since it is characterized by the lowest level of federal minimum wage over the 2004-2013 period (see Figure 3). We control for all the covariates introduced in Equation 14 and follow the same identification strategy as in the previous section.

Table 9 reports the IV estimates for the sample of men and the sample of men and women. As in the previous section, the results indicate an increasing protective effect which took place after the successive rises which started after 2008. We also find insignificant or negative estimates on the interaction terms between the pre-treatment periods and $p_{\text {ist }} \times$ Treated. The fact that the estimated coefficients are never positive for the years 2004 to 2006 provide suggestive evidence that an event occurred after 2008 which reduced the adverse labor market impact of immigration in low minimum wage states relative to high minimum wage states. Such event is very likely to be related to the federal minimum wage policy.

In some specifications of Table 9, we find negative and significant coefficients on the interaction terms between the pre-treatment periods and $p_{i s t} \times$ Treated. This result indicates that the detrimental impact of immigration in low minimum wage states has been stronger in these pre-treatment years (2004 to 2006) relative to the baseline year 2007 as compared to the control group of states. One reason may be that over the pre-treatment period, the minimum wage gap between the treated and control groups actually increased, reducing the protective effect of the minimum wage. Moreover, these results show that our DiD estimates do not capture any propensity in low minimum wage states to be less affected by immigration over the years. It is thus very likely that the three successive increase in the federal minimum wage mitigated the adverse labor market impact of immigration in low minimum wage states.

\subsection{Quantifying the Protective Effects of Federal Minimum Wage Increases}

This section uses the estimates from Table 8 to quantify the protective effects of the minimum wage in states where the federal minimum wage is binding. The upper panel of Table 10 shows the successive rises in the federal minimum wage and indicates that the share of male native workers paid at the minimum wage has doubled over the period, going from 4.7 percent before 2007 to 10.0 percent after 2010.

The middle and lower panels of Table provide estimates of the implied wage and employment elasticities to immigration for the group of low minimum wage states (i.e., when Treated $=1$ ). Lines A.1 and B.1 provide those elasticities based on the point estimates from our baseline IV 
specifications (see Table 8) and Equation 14. For example, over the 2004-2013 period, these elasticities are computed as follows:

$$
\begin{aligned}
\text { Implied Elasticity }= & {\left[\lambda_{1}+\lambda_{2}+\lambda_{3} \cdot \overline{d t_{2008}}+\lambda_{4} \cdot \overline{d t_{2009}}+\lambda_{5} \cdot \overline{d t_{2010}}\right.} \\
& \left.+\lambda_{6} \cdot \overline{d t_{2008}}+\lambda_{7} \cdot \overline{d t_{2009}}+\lambda_{8} \cdot \overline{d t_{2010}}\right] \cdot(1-p)^{2},
\end{aligned}
$$

where the average values of our time dummies are $\overline{d t_{2008}}=0.1, \overline{d t_{2009}}=0.1$ and $\overline{d t_{2010}}=0.4$. Over the 2004-2013 period, the average wage elasticity is -0.55 , implying that a 10 percent immigrant-induced increase in the labor supply should decreases the wage of natives with similar skills by 5.5 percent. The employment elasticity is $-0.26 .{ }^{48}$

Lines A.2 and B.2, on the other hand, provide counterfactual estimates for the same group of states in a scenario without "treatment", that is, as if there had been no change in the federal minimum wage after 2007 (i.e., assuming $\lambda_{6}=\lambda_{7}=\lambda_{8}=0$ in Equation 15). As one can see in Table 8, the implied elasticities before 2007 are obviously similar for the real and the counterfactual estimates. After 2007, the implied wage and employment elasticities are always more negative when assuming a constant federal minimum wage over the period. In particular, the federal minimum wage increase that occurred in 2010 reduced the wage elasticity to immigration by around 20.8 percent (from -0.72 to -0.57 ) and the employment elasticity by around 36.2 percent (from -0.32 to -0.20$).{ }^{49}$

\section{Conclusion}

We use the U.S. context and exploit exogenous federal minimum wage variations to identify the role of minimum wages in shaping the labor market effects of immigration. We use two

\footnotetext{
${ }^{48}$ Similarly, we can infer the employment and wage elasticities at different point in time. After 2010, e.g., the implied wage and employment elasticities are -0.57 and -0.20 respectively.

${ }^{49} \mathrm{On}$ the basis of an annual salary of $\$ 20,000$, going from a wage elasticity of -0.71 to -0.55 implies that a 10 percent immigrant-induced increase in labor supply reduces native earnings by $\$ 1,442$ instead of $\$ 1,142-$ i.e., a wage gain of around $\$ 299$ or a reduction in wage losses by around 1.5 percent. Similarly, the rise in the federal minimum wage in 2008 allowed to reduce the wage losses by around 1 percent (i.e., $\$ 218$ for an annual salary of $\$ 20,000$ ). Over the whole 2008-2013 period, the rises in the federal minimum wage therefore mitigated the wage losses of native workers due to immigration by about 3.3 percent (i.e., $0.7+1.1+1.5$ ), corresponding to an annual wage gain of $\$ 666$ (i.e., $\$ 150+\$ 218+\$ 299$ ) for an annual salary of $\$ 20,000$.
} 
complementary empirical strategies (standard panel estimations and a difference-in-differences approach) to estimate the impact of immigration on the wages and employment of native workers within a given state-skill cell. We thus go beyond the mean wage impact of immigration and identify heterogeneous labor market effects of immigration not only for different types of workers but also across U.S. States characterized by different labor market institutions, namely, different minimum wages.

Our first empirical strategy exploits the non-linearity of the minimum wage across U.S. States to investigate the role played by the minimum wage in shaping the impact of immigration on the wages and employment of competing native workers. We find that on average, immigration has relatively small detrimental effects on the wages and employment outcomes of competing native workers. The main contribution of this study is not to provide yet another estimate of the wage and employment responses to immigration but, rather, to investigate the role of minimum wages in determining such responses. Indeed, we show that the labor market effects of immigration are heterogeneous across U.S. States characterized by different levels of minimum wage. In particular, we find that the impact of immigration on natives' labor market outcomes is more negative in states where the effective minimum wage is relatively low. In contrast, sufficiently high minimum wages tend to protect native workers from any adverse wage or unemployment effects of immigration.

Our second empirical methodology uses a difference-in-differences approach. We use cross-state differences in the impact of federal minimum wage adjustments on state effective minimum wages. Over our period of interest, the successive rises in the federal minimum wage have fully affected the states where the effective minimum wage is equal to the federal one (the treatment group), with no impact in high minimum wage states (the control group). Thus, we can estimate the difference between the labor market impact of immigration before and after the federal policy changes between the treatment group and the control group. Our estimates indicate that the detrimental impact of immigration on natives' wages and employment have been mitigated thanks to the federal minimum wage increases that occurred in three installements between 2007 and 2010.

Taken together, our results indicate that high minimum wages tend to protect employed native workers against competition from immigrants. This may come at the price, obviously, of rendering access to employment more difficult for outsiders such as the unemployed natives 
and new immigrants, a question we cannot investigate given the limits of our data..$^{50}$

${ }^{50}$ Recall that ACS data do not contain the employment status of individuals one year prior to the survey nor the duration of unemployment spells. 


\section{References}

AltonJI, J. G., AND D. CARD (1991): "The effects of immigration on the labor market outcomes of less-skilled natives," in Immigration, trade and the labor market, pp. 201-234. University of Chicago Press.

ANGRIST, J. D., AND A. D. KUGLER (2003): "Protective or counter-productive? labour market institutions and the effect of immigration on EU natives," The Economic Journal, 113(488), F302-F331.

AYDEMIR, A., AND G. J. BORJAS (2007): "Cross-country variation in the impact of international migration: Canada, Mexico, and the United States," Journal of the European Economic Association, 5(4), 663-708.

AydemiR, A., AND G. J. BorJAs (2011): "Attenuation Bias in Measuring the Wage Impact of Immigration," Journal of Labor Economics, 29(1), 69-112.

BASKAYA, Y. S., AND Y. RUBinstein (2012): "Using federal minimum wages to identify the impact of minimum wages on employment and earnings across the US states," Discussion paper, mimeo.

Bertrand, M., E. Duflo, and S. Mullainathan (2004): "How Much Should We Trust Differences-in-Differences Estimates?," The Quarterly Journal of Economics, pp. 249-275.

Boffy-RAmiREZ, E. (2013): "Minimum wages, earnings, and migration," IZA Journal of Migration, 2(1), 17.

BORJAS, G. J. (2003): "The labor demand curve is downward sloping: reexamining the impact of immigration on the labor market," The Quarterly Journal of Economics, 118(4), 1335-1374.

BORJAS, G. J. (2006): "Native internal migration and the labor market impact of immigration," Journal of Human Resources, 41(2), 221-258.

_ (2014): Immigration Economics. Harvard University Press.

BORJAS, G. J. (2017): "The Wage Impact of the Marielitos: A Reappraisal," Industrial and Labor Relations Review, (21588). 
BorJas, G. J., R. B. Freeman, and L. F. Katz (1997): "How much do immigration and trade affect labor market outcomes?," Brookings papers on economic activity, 1997(1), 1-90.

BorJas, G. J., J. Grogger, and G. H. Hanson (2010): "Immigration and the Economic Status of African-American Men,” Economica, 77(306), 255-282.

Bratsberg, B., O. RaAum, M. Røed, and P. Schøne (2014): "Immigration Wage Effects by Origin," The Scandinavian Journal of Economics, 116(2), 356-393.

Brücker, H., A. Hauptmann, E. J. JAHn, and R. UpWARD (2014): "Migration and imperfect labor markets: Theory and cross-country evidence from Denmark, Germany and the UK," European Economic Review, 66, 205-225.

BRÜCKER, H., AND E. J. JAHN (2011): "Migration and Wage-setting: Reassessing the Labor Market Effects of Migration," The Scandinavian Journal of Economics, 113(2), 286-317.

CADENA, B. C. (2014): "Recent immigrants as labor market arbitrageurs: Evidence from the minimum wage," Journal of Urban Economics, 80, 1-12.

Cameron, A. C., AND D. L. Miller (2015): "A practitioner's guide to cluster-robust inference," Journal of Human Resources, 50(2), 317-372.

CARD, D. (1990): "The Impact of the Mariel Boatlift on the Miami Labor Market," Industrial and Labor Relations Review, 43(2), 245-257.

(1992): "Using regional variation in wages to measure the effects of the federal minimum wage," Industrial \& Labor Relations Review, 46(1), 22-37.

(2001): "Immigrant Inflows, Native Outflows, and the Local Labor Market Impacts of Higher Immigration," Journal of Labor Economics, 19(1), 22-64.

Card, D., and A. B. Krueger (1995): Myth and measurement. Princeton University Press Princeton, NJ.

(2000): "Minimum wages and employment: a case study of the fast-food industry in New Jersey and Pennsylvania: reply," The American Economic Review, 90(5), 1397-1420. 
Castillo-Freeman, A., and R. B. Freeman (1992): "When the minimum wage really bites: the effect of the US-level minimum on Puerto Rico," in Immigration and the workforce: Economic consequences for the United States and source areas, pp. 177-212. University of Chicago Press.

CORTES, P. (2008): "The effect of low-skilled immigration on US prices: evidence from CPI data," Journal of political Economy, 116(3), 381-422.

D'Amuri, F., G. I. Ottaviano, and G. Peri (2010): "The labor market impact of immigration in Western Germany in the 1990s," European Economic Review, 54(4), 550-570.

D'AmURI, F., AND G. PeRI (2014): "Immigration, jobs, and employment protection: Evidence from europe before and during the great recession," Journal of the European Economic Association, 12(2), 432-464.

Deere, D., K. M. Murphy, And F. Welch (1995): "Employment and the 1990-1991 minimumwage hike," The American Economic Review, pp. 232-237.

Dustmann, C., F. Fabbri, and I. Preston (2005): "The Impact of Immigration on the British Labour Market*," The Economic Journal, 115(507), F324-F341.

Dustmann, C., AND A. GLITZ (2015): "How do industries and firms respond to changes in local labor supply?," Journal of Labor Economics, 33(3 Part 1), 711-750.

DustmanN, C., U. SCHÖNBERG, AND J. STUHLER (2016): "Labor supply shocks, native wages, and the adjustment of local employment," The Quarterly Journal of Economics, p. qjw032.

Edo, A. (2016): "How do rigid labor markets absorb immigration? Evidence from France," IZA Journal of Migration, 5(1), 1-20.

Edo, A., ANd F. TOUBAL (2015): "Selective Immigration Policies and Wages Inequality," Review of International Economics, 23(1), 160-187.

Felbermayr, G., W. Geis, and W. Kohler (2010): "Restrictive immigration policy in Germany: pains and gains foregone?," Review of World Economics, 146(1), 1-21. 
Friedberg, R. M. (2001): "The impact of mass migration on the Israeli labor market," The Quarterly Journal of Economics, 116(4), 1373-1408.

FriedberG, R. M., AND J. HUNT (1995): "The impact of immigrants on host country wages, employment and growth," The Journal of Economic Perspectives, 9(2), 23-44.

GIULIETTI, C. (2014): "Is the minimum wage a pull factor for immigrants?," Industrial \& Labor Relations Review, 67(3 suppl), 649-674.

GLITZ, A. (2012): "The labor market impact of immigration: A quasi-experiment exploiting immigrant location rules in Germany," Journal of Labor Economics, 30(1), 175-213.

HUNT, J. (1992): "The impact of the 1962 repatriates from Algeria on the French labor market," Industrial and Labor Relations Review, pp. 556-572.

LEE, D. S. (1999): "Wage inequality in the United States during the 1980s: Rising dispersion or falling minimum wage?," The Quarterly Journal of Economics, pp. 977-1023.

LEWIS, E. (2011): "Immigration, skill mix, and capital skill complementarity," The Quarterly Journal of Economics, 126(2), 1029-1069.

MANACORDA, M., A. MANNING, AND J. WADSWORTH (2012): "The Impact of Immigration on the Structure of Wages: Theory and Evidence from Britain," Journal of the European Economic Association, 10, 120-151.

MCKENZIE, D., AND H. RAPOPORT (2010): "Self-selection patterns in Mexico-US migration: the role of migration networks," The Review of Economics and Statistics, 92(4), 811-821.

MONRAS, J. (2015): "Immigration and wage dynamics: Evidence from the mexican peso crisis," IZA discussion paper.

MUNSHI, K. (2003): "Networks in the modern economy: Mexican migrants in the US labor market," The Quarterly Journal of Economics, pp. 549-599.

Naidu, S., Y. Nyarko, N. A. Dhabi, and S.-Y. WAng (2015): "Monopsony Power in Migrant Labor Markets: Evidence from the United Arab Emirates," Journal of Political Economy, forthcoming. 
NeUmark, D., AND W. WAScher (1992): "Employment effects of minimum and subminimum wages: panel data on state minimum wage laws," Industrial \& Labor Relations Review, 46(1), 55-81.

(2006): "Minimum wages and employment: A review of evidence from the new minimum wage research," Discussion paper, National Bureau of Economic Research.

OrRenius, P. M., ANd M. Zavodny (2007): "Does immigration affect wages? A look at occupation-level evidence," Labour Economics, 14(5), 757-773.

(2008): "The effect of minimum wages on immigrants' employment and earnings," Industrial \& Labor Relations Review, 61(4), 544-563.

ORTEGA, J., AND G. Verdugo (2014): "The impact of immigration on the French labor market: Why so different?," Labour Economics, 29, 14-27.

OtTAVIANO, G. I., AND G. PERI (2012): "Rethinking the effects of immigration on wages," Journal of the European Economic Association, 10, 152-197.

PERI, G. (2012): "The effect of immigration on productivity: Evidence from US states," Review of Economics and Statistics, 94(1), 348-358.

Peri, G., And C. Sparber (2009): "Task specialization, immigration, and wages," American Economic Journal: Applied Economics, pp. 135-169.

Peri, G., and C. Sparber (2011a): "Assessing inherent model bias: An application to native displacement in response to immigration," Journal of Urban Economics, 69(1), 82-91.

_ (2011b): "Highly Educated Immigrants and Native Occupational Choice," Industrial Relations: A Journal of Economy and Society, 50(3), 385-411.

Peri, G., And V. Yasenov (2015): "The Labor Market Effects of a Refugee Wave: Applying the Synthetic Control Method to the Mariel Boatlift," Discussion paper, National Bureau of Economic Research.

SMITH, C. L. (2012): "The impact of low-skilled immigration on the youth labor market," Journal of Labor Economics, 30(1), 55-89. 
STEINHARDT, M. F. (2011): "The wage impact of immigration in germany-new evidence for skill groups and occupations," The BE Journal of Economic Analysis \& Policy, 11(1).

Stock, J. H., J. H. WRIGHT, AND M. YOGO (2002): "A survey of weak instruments and weak identification in generalized method of moments," Journal of Business \& Economic Statistics, 20(4).

THOMPSON, J. P. (2009): "Using local labor market data to re-examine the employment effects of the minimum wage," Industrial \& Labor Relations Review, 62(3), 343-366.

ZAVODNY, M. (2014): "Who benefits from the minimum wage-natives or migrants?," IZA World of Labor. 


\section{Supplementary Material}

\section{A Descriptive Statistics}

Table 11: Immigrant Share and Effective Minimum Wage, 2000-2013

\begin{tabular}{|c|c|c|c|c|c|c|c|}
\hline States & $\begin{array}{l}\text { Immigrant } \\
\text { Share }\end{array}$ & $\begin{array}{c}\text { Effective } \\
\text { MW (\$) }\end{array}$ & $\begin{array}{c}\text { Workers } \\
\text { at the MW } \\
(\%)\end{array}$ & States & $\begin{array}{l}\text { Immigrant } \\
\text { Share }\end{array}$ & $\begin{array}{c}\text { Effective } \\
\text { MW (\$) }\end{array}$ & $\begin{array}{l}\text { Workers } \\
\text { at the MW } \\
(\%)\end{array}$ \\
\hline Alabama & 4.7 & 4.8 & 7.1 & Montana & 1.5 & 5.0 & 9.8 \\
\hline Alaska & 6.4 & 5.8 & 7.1 & Nebraska & 7.8 & 4.8 & 6.4 \\
\hline Arizona & 21.0 & 5.1 & 6.9 & Nevada & 26.2 & 5.1 & 5.9 \\
\hline Arkansas & 6.6 & 4.9 & 8.5 & New Hampshire & 6.0 & 4.9 & 3.7 \\
\hline California & 38.1 & 5.9 & 7.8 & New Jersey & 28.1 & 5.1 & 4.0 \\
\hline Colorado & 13.6 & 5.1 & 5.9 & New Mexico & 13.8 & 5.0 & 9.0 \\
\hline Connecticut & 17.1 & 6.1 & 5.1 & New York & 28.6 & 5.2 & 5.6 \\
\hline Delaware & 11.2 & 5.4 & 6.4 & North Carolina & 11.8 & 4.9 & 6.5 \\
\hline District of Col. & 19.4 & 5.8 & 6.4 & North Dakota & 2.4 & 4.8 & 6.0 \\
\hline Florida & 24.9 & 5.1 & 7.4 & Ohio & 4.6 & 5.1 & 6.7 \\
\hline Georgia & 14.8 & 4.8 & 6.2 & Oklahoma & 8.0 & 4.8 & 7.5 \\
\hline Hawaii & 18.5 & 5.4 & 6.4 & Oregon & 13.5 & 6.3 & 10.3 \\
\hline Idaho & 8.7 & 4.8 & 7.1 & Pennsylvania & 6.7 & 5.0 & 5.5 \\
\hline Illinois & 20.3 & 5.5 & 6.5 & Rhode Island & 16.6 & 5.7 & 5.3 \\
\hline Indiana & 5.9 & 4.8 & 5.7 & South Carolina & 6.9 & 4.8 & 6.9 \\
\hline lowa & 5.3 & 5.0 & 6.1 & South Dakota & 2.7 & 4.8 & 7.4 \\
\hline Kansas & 8.6 & 4.8 & 5.8 & Tennessee & 6.6 & 4.8 & 6.9 \\
\hline Kentucky & 4.3 & 4.8 & 7.5 & Texas & 24.3 & 4.8 & 6.9 \\
\hline Louisiana & 5.0 & 4.8 & 8.1 & Utah & 12.0 & 4.8 & 5.6 \\
\hline Maine & 2.8 & 5.4 & 7.1 & Vermont & 3.7 & 6.0 & 8.1 \\
\hline Maryland & 17.1 & 4.9 & 4.3 & Virginia & 14.3 & 4.8 & 4.9 \\
\hline Massachusetts & 18.3 & 6.0 & 5.0 & Washington & 15.5 & 6.4 & 8.2 \\
\hline Michigan & 7.7 & 5.1 & 6.8 & West Virginia & 1.5 & 5.0 & 8.6 \\
\hline Minnesota & 8.3 & 5.0 & 4.7 & Wisconsin & 5.8 & 5.0 & 5.4 \\
\hline Mississippi & 3.1 & 4.8 & 8.7 & Wyoming & 3.3 & 4.8 & 6.1 \\
\hline Missouri & 4.7 & 5.0 & 6.8 & United States & 17.6 & 5.2 & 6.5 \\
\hline
\end{tabular}


Table 12: Share of Male Immigrants in 2000 and 2013 across Skill Groups

\begin{tabular}{|c|c|c|c|c|c|c|c|c|c|}
\hline \multirow[b]{2}{*}{ Education } & \multirow[b]{2}{*}{ Years of Experience } & \multicolumn{2}{|c|}{$\begin{array}{l}\text { All U.S. } \\
\text { States }\end{array}$} & \multicolumn{2}{|c|}{$\begin{array}{c}\text { High MW } \\
\text { States }\end{array}$} & \multicolumn{2}{|c|}{$\begin{array}{c}\text { Medium MW } \\
\text { States }\end{array}$} & \multicolumn{2}{|c|}{$\begin{array}{l}\text { Low MW } \\
\text { States }\end{array}$} \\
\hline & & 2000 & 2013 & 2000 & 2013 & 2000 & 2013 & 2000 & 2013 \\
\hline \multirow[t]{8}{*}{ High school dropouts } & $1-5$ & 33.6 & 25.5 & 53.1 & 37.4 & 28.3 & 22.5 & 29.2 & 23.7 \\
\hline & $6-10$ & 47.7 & 43.7 & 69.7 & 61.6 & 40.9 & 37.5 & 40.2 & 41.0 \\
\hline & $11-15$ & 47.4 & 53.6 & 71.7 & 69.2 & 39.2 & 49.9 & 39.0 & 47.7 \\
\hline & $16-20$ & 43.5 & 60.7 & 71.3 & 77.8 & 35.6 & 55.3 & 32.5 & 54.6 \\
\hline & $21-25$ & 37.3 & 62.3 & 67.6 & 82.0 & 30.0 & 56.0 & 26.4 & 54.1 \\
\hline & $26-30$ & 37.3 & 59.1 & 69.4 & 81.4 & 30.9 & 51.2 & 24.8 & 49.8 \\
\hline & $31-35$ & 35.1 & 50.3 & 68.8 & 75.8 & 31.0 & 41.7 & 20.5 & 40.3 \\
\hline & $36-40$ & 26.0 & 48.4 & 56.3 & 76.5 & 23.6 & 39.7 & 13.9 & 37.5 \\
\hline \multirow[t]{8}{*}{ High school graduates } & $1-5$ & 11.8 & 10.2 & 21.5 & 15.0 & 10.5 & 9.3 & 8.3 & 8.6 \\
\hline & $6-10$ & 14.3 & 17.1 & 27.4 & 25.3 & 12.7 & 15.6 & 9.3 & 14.0 \\
\hline & $11-15$ & 13.1 & 20.4 & 27.0 & 32.0 & 11.5 & 18.4 & 7.7 & 16.2 \\
\hline & $16-20$ & 10.5 & 22.1 & 21.5 & 37.2 & 9.8 & 20.6 & 5.4 & 15.9 \\
\hline & $21-25$ & 9.1 & 21.4 & 18.5 & 38.9 & 8.8 & 19.5 & 4.5 & 15.0 \\
\hline & $26-30$ & 9.2 & 17.4 & 18.8 & 33.2 & 9.2 & 15.7 & 4.4 & 11.3 \\
\hline & $31-35$ & 9.5 & 13.6 & 19.6 & 26.0 & 9.8 & 12.8 & 3.9 & 8.2 \\
\hline & $36-40$ & 7.8 & 12.7 & 15.4 & 25.1 & 8.1 & 12.1 & 3.4 & 7.3 \\
\hline \multirow[t]{8}{*}{ Some college } & $1-5$ & 8.2 & 8.2 & 15.3 & 12.6 & 7.7 & 8.3 & 4.9 & 5.5 \\
\hline & $6-10$ & 9.1 & 10.3 & 17.2 & 16.1 & 8.3 & 9.9 & 5.2 & 7.1 \\
\hline & $11-15$ & 9.9 & 12.5 & 17.9 & 18.9 & 9.2 & 12.6 & 5.4 & 8.1 \\
\hline & $16-20$ & 9.4 & 13.9 & 16.9 & 23.5 & 8.7 & 13.4 & 5.2 & 8.9 \\
\hline & $21-25$ & 8.0 & 13.5 & 14.3 & 25.3 & 7.5 & 11.8 & 4.3 & 8.6 \\
\hline & $26-30$ & 7.2 & 13.1 & 12.3 & 23.1 & 6.9 & 11.8 & 3.7 & 8.2 \\
\hline & $31-35$ & 6.9 & 10.7 & 11.1 & 19.4 & 7.0 & 9.9 & 3.4 & 6.0 \\
\hline & $36-40$ & 7.2 & 9.9 & 12.2 & 16.7 & 7.1 & 9.2 & 3.4 & 6.3 \\
\hline \multirow[t]{8}{*}{ College graduates } & $1-5$ & 13.4 & 12.5 & 21.7 & 17.1 & 12.4 & 12.0 & 8.6 & 9.5 \\
\hline & $6-10$ & 14.9 & 17.8 & 22.8 & 24.9 & 13.9 & 17.1 & 10.2 & 13.1 \\
\hline & $11-15$ & 15.6 & 21.0 & 23.3 & 30.9 & 14.6 & 20.0 & 10.8 & 14.9 \\
\hline & $16-20$ & 14.1 & 21.0 & 20.9 & 30.7 & 13.5 & 19.4 & 9.5 & 15.9 \\
\hline & $21-25$ & 11.9 & 19.0 & 18.2 & 27.0 & 11.3 & 18.1 & 7.8 & 14.1 \\
\hline & $26-30$ & 10.4 & 17.7 & 15.6 & 26.3 & 10.3 & 16.1 & 6.2 & 13.9 \\
\hline & $31-35$ & 10.8 & 14.9 & 15.0 & 21.6 & 11.1 & 14.2 & 6.5 & 10.9 \\
\hline & $36-40$ & 13.0 & 12.8 & 18.5 & 20.0 & 13.5 & 12.1 & 7.5 & 8.2 \\
\hline
\end{tabular}


Table 13: Share of Male Native Workers at the Minimum Wage, 2000-2013

\begin{tabular}{|c|c|c|c|c|c|c|c|c|c|}
\hline \multirow[b]{2}{*}{ Education } & \multirow[b]{2}{*}{ Years of Experience } & \multicolumn{4}{|c|}{ All U.S. States } & \multicolumn{2}{|c|}{ Indiana } & \multicolumn{2}{|c|}{ Oregon } \\
\hline & & 2000 & 2005 & 2010 & 2013 & 2000 & 2013 & 2000 & 2013 \\
\hline \multirow[t]{8}{*}{ High school dropouts } & $1-5$ & 29.2 & 30.6 & 49.8 & 47.2 & 23.4 & 45.5 & 39.0 & 57.4 \\
\hline & $6-10$ & 16.7 & 17.8 & 31.5 & 32.1 & 12.5 & 37.4 & 22.4 & 49.1 \\
\hline & $11-15$ & 12.0 & 12.8 & 22.8 & 22.7 & 6.4 & 28.1 & 23.7 & 28.8 \\
\hline & $16-20$ & 10.7 & 11.0 & 20.5 & 18.0 & 8.2 & 20.9 & 14.8 & 19.7 \\
\hline & $21-25$ & 9.5 & 9.3 & 17.2 & 16.1 & 7.1 & 16.4 & 14.6 & 22.4 \\
\hline & $26-30$ & 9.0 & 8.5 & 15.5 & 14.4 & 9.4 & 16.9 & 14.7 & 32.6 \\
\hline & $31-35$ & 7.9 & 8.7 & 14.9 & 14.9 & 4.6 & 14.7 & 11.7 & 42.3 \\
\hline & $36-40$ & 6.9 & 7.4 & 15.4 & 12.5 & 5.0 & 11.0 & 14.3 & 10.2 \\
\hline \multirow[t]{8}{*}{ High school graduates } & $1-5$ & 15.6 & 18.0 & 33.6 & 35.0 & 10.5 & 33.6 & 23.9 & 43.3 \\
\hline & $6-10$ & 7.6 & 7.7 & 17.5 & 18.3 & 4.9 & 16.1 & 13.1 & 25.5 \\
\hline & $11-15$ & 5.8 & 6.2 & 13.8 & 14.1 & 3.7 & 13.7 & 9.4 & 19.1 \\
\hline & $16-20$ & 4.8 & 4.7 & 9.8 & 10.0 & 3.8 & 5.8 & 7.8 & 12.8 \\
\hline & $21-25$ & 4.5 & 4.4 & 8.8 & 9.6 & 3.0 & 8.9 & 6.6 & 13.1 \\
\hline & $26-30$ & 4.1 & 4.0 & 7.8 & 8.1 & 3.1 & 6.7 & 7.3 & 18.0 \\
\hline & $31-35$ & 3.9 & 3.9 & 8.3 & 7.1 & 2.4 & 7.1 & 8.5 & 13.3 \\
\hline & $36-40$ & 3.7 & 3.9 & 7.0 & 6.9 & 3.2 & 7.2 & 6.1 & 8.4 \\
\hline \multirow[t]{8}{*}{ Some college } & $1-5$ & 8.1 & 9.1 & 20.5 & 22.1 & 5.1 & 22.3 & 13.0 & 36.0 \\
\hline & $6-10$ & 3.9 & 3.9 & 9.6 & 10.8 & 3.1 & 9.9 & 6.2 & 15.7 \\
\hline & $11-15$ & 3.0 & 3.3 & 6.8 & 7.2 & 2.1 & 6.6 & 4.7 & 12.4 \\
\hline & $16-20$ & 2.9 & 3.0 & 6.1 & 5.5 & 3.1 & 4.9 & 5.2 & 8.1 \\
\hline & $21-25$ & 3.1 & 2.9 & 5.1 & 5.5 & 3.1 & 5.2 & 5.2 & 7.4 \\
\hline & $26-30$ & 3.0 & 3.0 & 5.2 & 5.1 & 2.8 & 2.9 & 4.7 & 5.6 \\
\hline & $31-35$ & 3.2 & 3.2 & 5.5 & 5.0 & 2.6 & 4.5 & 4.3 & 7.4 \\
\hline & $36-40$ & 3.6 & 3.5 & 6.5 & 6.0 & 3.4 & 5.5 & 5.5 & 10.7 \\
\hline \multirow[t]{8}{*}{ College graduates } & $1-5$ & 3.1 & 3.3 & 7.9 & 8.2 & 2.8 & 8.5 & 6.1 & 17.9 \\
\hline & $6-10$ & 2.0 & 1.5 & 3.5 & 3.8 & 1.4 & 3.5 & 3.6 & 12.4 \\
\hline & $11-15$ & 1.9 & 1.7 & 2.7 & 2.4 & 1.6 & 3.0 & 2.5 & 2.7 \\
\hline & $16-20$ & 2.2 & 1.5 & 2.3 & 2.3 & 1.9 & 3.1 & 3.1 & 5.8 \\
\hline & $21-25$ & 2.4 & 1.7 & 2.7 & 2.4 & 2.6 & 2.6 & 3.2 & 4.3 \\
\hline & $26-30$ & 2.5 & 1.8 & 2.7 & 2.5 & 2.0 & 2.4 & 4.8 & 3.3 \\
\hline & $31-35$ & 2.8 & 2.5 & 3.2 & 2.9 & 2.2 & 1.7 & 4.5 & 3.0 \\
\hline & $36-40$ & 4.2 & 3.4 & 4.5 & 4.0 & 3.8 & 4.4 & 7.3 & 6.6 \\
\hline
\end{tabular}


Figure 8: Weekly Wage, Employment and Immigrant Share, 2000-2013, Men
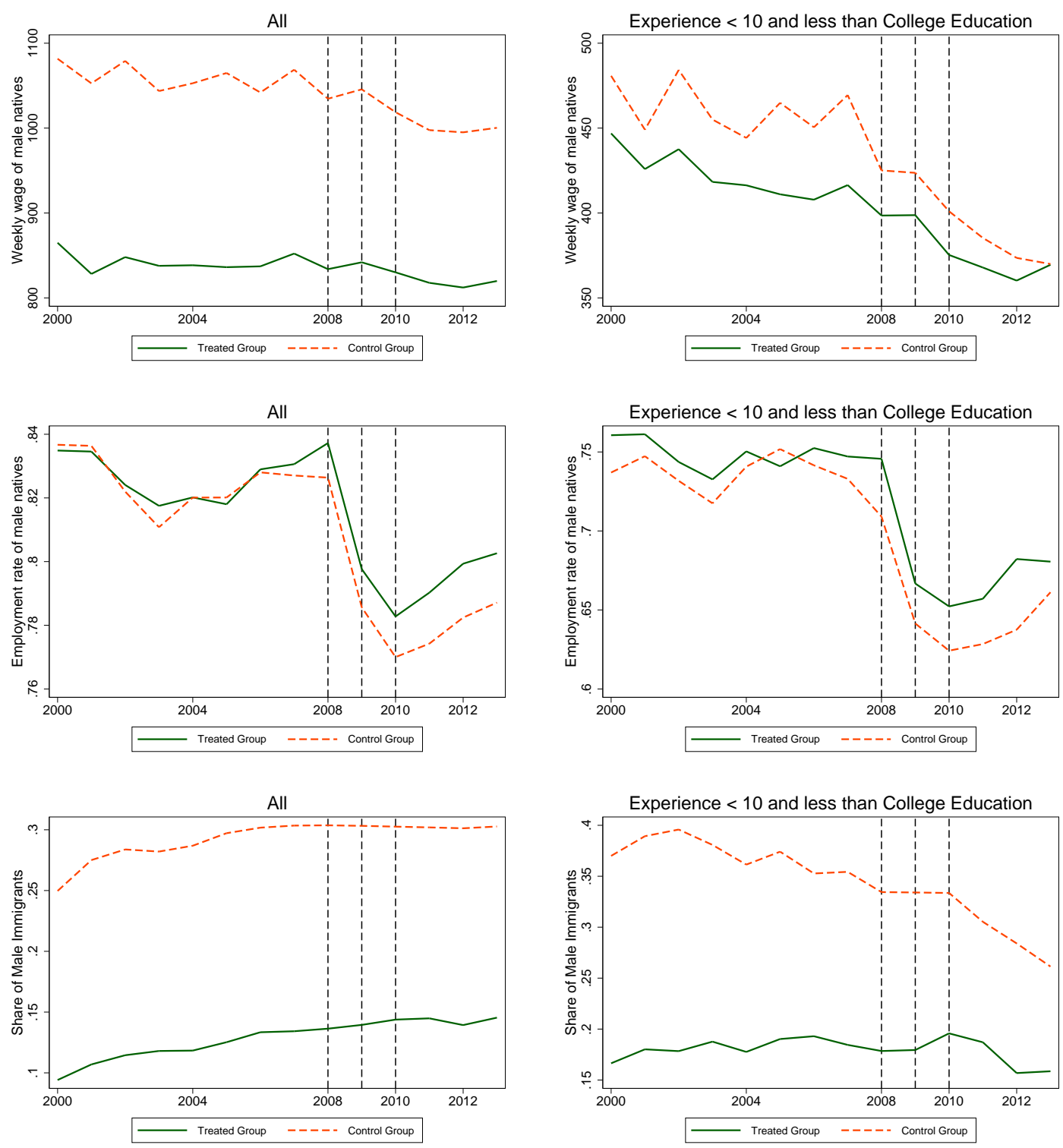
Figure 9: Ratio between the Number of College vs Non-College Workers, 2000-2013, Men

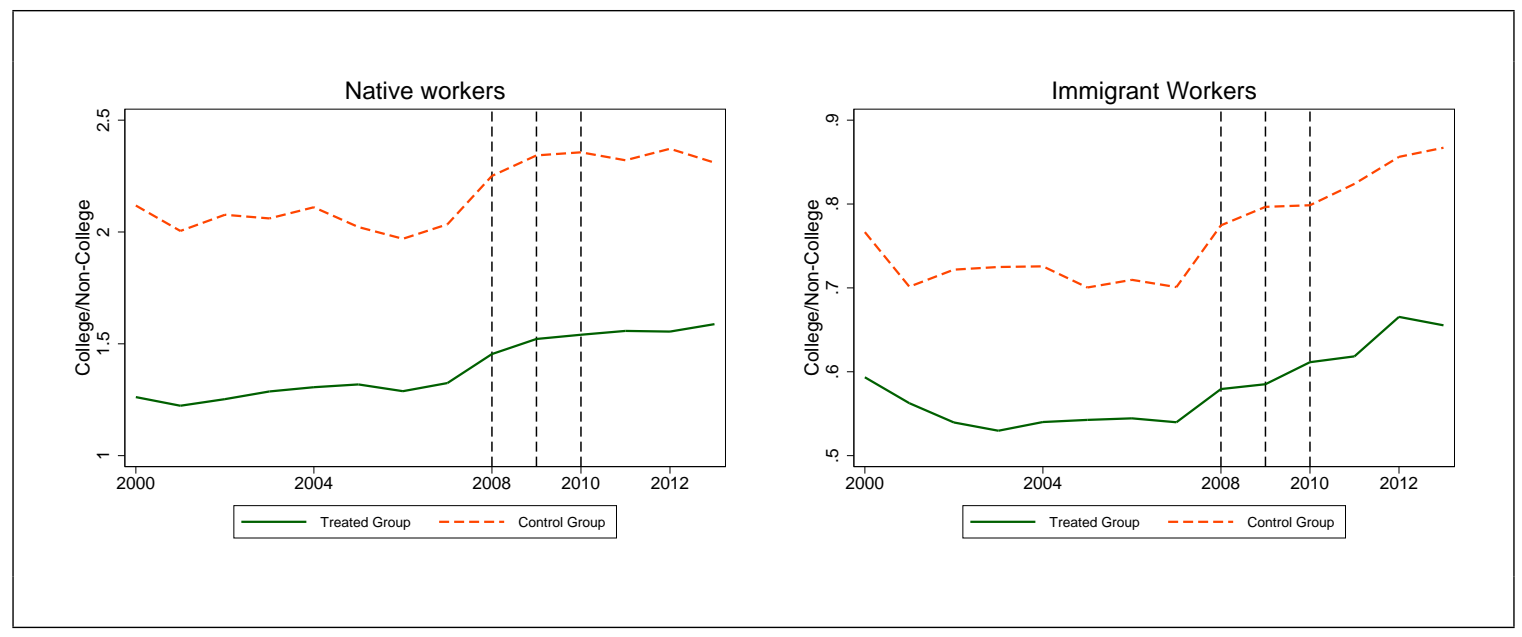

\section{B Is Immigration Causing "Native Flight"?}

This section examines the impact of immigration on the internal migration of equally skilled natives. In order to avoid wage and employment losses due to immigration, native workers may be inclined to move to other states (Borjas, Freeman, and Katz, 1997; Card, 2001; Dustmann, Fabbri, and Preston, 2005). We follow Borjas (2006) and investigate whether or not immigration affected native internal migration over our period of interest. ${ }^{51}$ Moreover, we would expect the internal migration of natives to be magnified in states-skill cells with relatively low minimum wages (i.e., where immigration has significant negative wage and employment effects) - see our implication 5 in section 2.

Table 14 uses two sets of dependent variables: the net-migration rate of natives in Panel A, and the out-migration rate of natives in Panel B, as proposed by Borjas (2006). In order to increase the number of observations used to compute the numerators of these two ratios, we use four education groups (each spanning an interval of 10 years) instead of eight. ${ }^{52}$ This strategy should limit any measurement error in the computation of the net- and out-migration

\footnotetext{
${ }^{51}$ Borjas (2006) defines local labor market at the state level and shows that immigration is associated with higher out-migration rates among natives.

${ }^{52}$ In the sample with four experience groups, $11 \%$ of skill groups have less than 100 observations to compute the number of out-migrants; instead of $22 \%$ when using the sample with eight experience groups.
} 
rates of natives, and therefore, reduce potential attenuation bias.

Table 14 reports the estimated effects of the immigrant share and its interaction with $M W_{s t}$, which is the state's effective minimum wage, on internal migration across states. We use the samples of men as well as men and women for each Panel. We also provide the OLS estimates and two sets of IV estimates. The instrument used in specifications 2 and 5 does not endogenize the number of natives (i.e., the instrument is $\hat{M}_{i s t} /\left(\hat{M}_{i s t}+N_{i s t}\right)$ ), as suggested by Borjas (2014); while specifications 3 and 6 endogenize the native labor supply (i.e., the instrument is $\hat{M}_{i s t} /\left(\hat{M}_{i s t}+\hat{N}_{i s t}\right)$ ), as suggested by Peri and Sparber (2011a). We use the same type of weights as in Table 3: we weight regressions by the share of natives in the labor force per cell in a given year. We cluster standard errors at the state-skill cell level. ${ }^{53}$

Our estimates indicate that immigration has a positive impact on the net- and out-migration rates of natives, except in specification 3 for the sample of men and specification 6 for the whole sample which indicate no displacement effect. Not surprisingly, the OLS coefficients tend to display a negative bias which suggests that the factors that explain immigrants in-migration also contribute to discourage native outflows. Moreover, the native displacement effect due to immigration is larger when we do not instrument the native labor supply (specifications 2 and 5). At the mean value of our sample $\left(\overline{M W}_{s t}=5.16\right)$, our IV estimated coefficients (from specification 2) indicate that 4 to 8 more natives (on net) move to a particular state for every 100 immigrants who enter that state. When we endogenize the native labor supply, the displacement is around 1 native for 100 migrants. The results presented in Panel B suggests that these effects are mostly driven by the out-migration of natives. More generally, our estimates indicate a weaker positive relationship between immigration and native internal migration than in Borjas (2006) who find a displacement effect of around 20 natives for every 100 immigrants that enter a particular state. Our results thus suggest that native internal migration are unlikely to bias our parameter values from our wage and employment regressions.

Moreover, our estimated coefficients on the interaction term always have the expected sign and are mostly significant for the sample of men and women, as well as for the sample of men in specification 6. In fact, the impact of the immigrant share on the "native flight" is negatively correlated with the state effective minimum wage, pointing to a disincentive effect of the minimum

\footnotetext{
${ }^{53}$ The estimates presented in Table 14 are not sensitive to the inclusion of the mean log wage of natives, which should control for factors that, in addition to immigration, may affect the decision among natives to migrate to another state.
} 
wage on native out-migration decision. In specification 6, e.g., the range of the displacement effect varies from 1.4 in low minimum wage states to 0.2 in high minimum wage states. 


\section{Additional OLS Estimates}

Table 15: OLS Estimates and Alternative Specifications

\begin{tabular}{|c|c|c|c|c|c|}
\hline \multicolumn{2}{|l|}{ Specification } & Weekly Wage & Hourly Wage & $\begin{array}{l}\text { Employment to } \\
\text { Labor Force }\end{array}$ & $\begin{array}{c}\text { Employment to } \\
\text { Population }\end{array}$ \\
\hline & & \multicolumn{4}{|c|}{ A. Two-Year Observations $(t=7)$} \\
\hline \multirow[t]{4}{*}{ 1. Men } & $p_{i s t}$ & $-0.43^{\star * *}$ & $-0.43^{\star * *}$ & $-0.15^{\star \star}$ & $-0.30^{* * *}$ \\
\hline & & $(-4.28)$ & $(-4.81)$ & $(-2.51)$ & $(-3.46)$ \\
\hline & $p_{i s t} \times M W_{s t}$ & $0.08^{\star * *}$ & $0.08^{\star \star *}$ & $0.02^{* *}$ & 0.02 \\
\hline & & $(4.22)$ & $(4.70)$ & $(1.97)$ & $(1.47)$ \\
\hline \multirow[t]{4}{*}{ 2. Men and Women } & $p_{i s t}$ & $-0.38^{\star \star \star}$ & $-0.33^{\star \star \star}$ & $-0.20^{\star \star \star}$ & $-0.50^{\star \star \star}$ \\
\hline & & $(-4.51)$ & $(-4.32)$ & $(-4.07)$ & $(-5.97)$ \\
\hline & $p_{i s t} \times M W_{s t}$ & $0.07^{\star \star \star}$ & $0.06^{\star \star \star}$ & $0.03^{\star \star \star}$ & $0.06^{\star \star \star}$ \\
\hline & & $(4.70)$ & $(4.54)$ & $(3.56)$ & $(4.04)$ \\
\hline
\end{tabular}

B. Add Share of Natives at the MW and its interaction

\begin{tabular}{|c|c|c|c|c|c|}
\hline \multirow{3}{*}{ 3. Men } & \multirow{3}{*}{$p_{i s t}^{m i g}$} & & & & \\
\hline & & $-0.43^{\star * \star}$ & $-0.44^{\star \star \star}$ & $-0.15^{\star \star \star}$ & $-0.31^{\star \star \star}$ \\
\hline & & $(-5.22)$ & $(-6.07)$ & $(-2.89)$ & $(-4.02)$ \\
\hline & \multirow{2}{*}{$p_{i s t}^{m i g} \times M W_{s t}$} & $0.09^{\star \star \star}$ & $0.08^{\star \star \star}$ & $0.02^{\star \star}$ & 0.02 \\
\hline & & $(5.43)$ & $(6.30)$ & $(2.34)$ & $(1.60)$ \\
\hline \multirow[t]{4}{*}{ 4. Men and Women } & \multirow[t]{2}{*}{$p_{i s t}^{m i g}$} & $-0.33^{\star \star \star}$ & $-0.29^{\star \star \star}$ & $-0.16^{\star \star \star}$ & $-0.48^{\star \star \star}$ \\
\hline & & $(-4.85)$ & $(-4.70)$ & $(-3.36)$ & $(-6.28)$ \\
\hline & \multirow[t]{2}{*}{$p_{i s t}^{m i g} \times M W_{s t}$} & $0.07^{\star * *}$ & $0.06^{\star * *}$ & $0.03^{\star \star *}$ & $0.05^{\star \star \star}$ \\
\hline & & $(5.36)$ & $(5.24)$ & $(3.03)$ & (3.79) \\
\hline
\end{tabular}

C. Alternative $M W_{s t}=E M W_{s t} /$ Median $W_{\text {age }}$ st

\begin{tabular}{|c|c|c|c|c|c|}
\hline \multirow{5}{*}{ 3. Men } & \multirow{3}{*}{$p_{i s t}$} & & & & \\
\hline & & $-0.18^{\star \star \star}$ & $-0.22^{\star \star \star}$ & $-0.16^{\star \star \star}$ & $-0.29^{\star \star \star}$ \\
\hline & & $(-2.58)$ & $(-3.46)$ & $(-3.37)$ & $(-4.15)$ \\
\hline & \multirow[t]{2}{*}{$p_{i s t} \times M W_{s t}$} & $0.53^{\star \star}$ & $0.61^{\star \star \star}$ & $0.39^{\star \star \star}$ & 0.31 \\
\hline & & $(2.52)$ & (3.31) & $(2.72)$ & $(1.48)$ \\
\hline \multirow[t]{4}{*}{ 4. Men and Women } & \multirow[t]{2}{*}{$p_{i s t}$} & $-0.19 * \star \star$ & $-0.16^{\star \star \star}$ & $-0.16^{\star \star \star}$ & $-0.41^{\star \star \star}$ \\
\hline & & $(-2.89)$ & $(-2.70)$ & $(-3.68)$ & $(-5.79)$ \\
\hline & \multirow[t]{2}{*}{$p_{i s t} \times M W_{s t}$} & $0.54^{\star \star \star}$ & $0.45^{\star \star \star}$ & $0.38^{\star \star \star}$ & $0.54^{\star \star *}$ \\
\hline & & $(3.15)$ & $(2.94)$ & $(3.28)$ & $(2.94)$ \\
\hline
\end{tabular}

Key. ${ }^{* * *},{ }^{* *},{ }^{*}$ denote statistical significance from zero at the 1\%,5\%,10\% significance level. T-statistics are indicated in parentheses below the point estimate.

Notes. The regressions in Panel A deals with at least 11,422 observations. In Panels B and C, columns 1 and 2 have 22,847 observations, while they have 22,836 observations in columns 3 and 4 . We weight wage regressions by the share of natives used to compute the dependent variable per year. We weight employment regressions by the share of the native labor force for a given year across cells. Standard errors are adjusted for clustering within state-education-experience cells. 


\section{Additional IV Estimates}

Table 16: IV Estimates using Alternative Instruments

\begin{tabular}{|c|c|c|c|c|c|}
\hline \multirow[t]{2}{*}{ Specification } & & Weekly Wage & Hourly Wage & $\begin{array}{l}\text { Employment to } \\
\text { Labor Force }\end{array}$ & $\begin{array}{c}\text { Employment to } \\
\text { Population }\end{array}$ \\
\hline & & \multicolumn{4}{|c|}{ A. Alternative Instrument: $\hat{p}_{i s t}=\hat{M}_{i s t} /\left(\hat{M}_{i s t}+N_{i s t}\right)$} \\
\hline \multirow[t]{2}{*}{ 1. Men } & $p_{i s t}$ & $\begin{array}{l}-0.54^{\star \star \star} \\
(-4.53)\end{array}$ & $\begin{array}{l}-0.52^{\star \star \star} \\
(-5.29)\end{array}$ & $\begin{array}{l}-0.40^{\star * \star} \\
(-5.22)\end{array}$ & $\begin{array}{l}-0.47^{\star \star \star} \\
(-4.24)\end{array}$ \\
\hline & $p_{i s t} \times M W_{s t}$ & $\begin{array}{c}0.09 * \star \star \\
(4.45)\end{array}$ & $\begin{array}{c}0.09 * \star * \\
(5.27)\end{array}$ & $\begin{array}{c}0.06^{\star \star \star} \\
(5.01)\end{array}$ & $\begin{array}{c}0.07^{\star \star \star} \\
(4.01)\end{array}$ \\
\hline \multirow[t]{2}{*}{ 2. Men and Women } & $p_{i s t}$ & $\begin{array}{l}-0.46^{\star \star \star} \\
(-4.46)\end{array}$ & $\begin{array}{l}-0.39^{\star \star \star} \\
(-4.60)\end{array}$ & $\begin{array}{l}-0.38^{\star \star \star} \\
(-5.33)\end{array}$ & $\begin{array}{l}-0.56^{\star \star \star} \\
(-5.30)\end{array}$ \\
\hline & $p_{i s t} \times M W_{s t}$ & $\begin{array}{c}\mathbf{0 . 0 9} \\
(4.94)\end{array}$ & $\begin{array}{c}\mathbf{0 . 0 7} \\
(4.97)\end{array}$ & $\begin{array}{c}\mathbf{0 . 0 6} \mathbf{6}^{\star \star *} \\
(5.33)\end{array}$ & $\begin{array}{c}0.10^{\star * *} \\
(5.89)\end{array}$ \\
\hline
\end{tabular}

\section{B. Alternative Instrument including Distance}

3. Men

$p_{\text {ist }}$

$-0.81^{\star \star \star}$

$-0.68^{\star \star *}$

$-0.45^{\star \star \star}$

$-0.62^{\star \star *}$

$(-4.57)$

$(-4.55)$

$(-4.27)$

$(-4.41)$

$p_{i s t} \times M W_{s t}$

$0.11^{\star \star *}$

$0.12^{\star \star \star}$

$0.05^{\star \star *}$

$0.07^{\star \star \star}$

(3.69)

(4.52)

(3.20)

\section{Men and Women $p_{i s t}$ \\ $-0.67^{\star \star \star}$ \\ $(-4.00)$ \\ $p_{\text {ist }} \times M W_{s t}$ \\ $0.12^{\star \star *}$}

$-0.49^{\text {** }}$

-0.50 ***

$-0.80^{* \star *}$

$(-3.66)$

$0.10^{\star \star *}$

$(-4.73)$

$0.06^{\star \star *}$

$(-5.59)$

(4.84)

(4.78)

(3.89)

$0.10^{\star \star \star}$

$(4.88)$

Key. ${ }^{* * *},{ }^{* *},{ }^{*}$ denote statistical significance from zero at the $1 \%, 5 \%, 10 \%$ significance level. T-statistics are indicated in parentheses below the point estimate.

Notes. Each regression has around 22,848 observations (i.e., 4 education groups, 8 experience groups, 51 states and 14 years of data). We weight wage regressions by the share of natives used to compute the dependent variable per year. The employment regressions are weighted by the share of the native labor force for a given year across cells. Standard errors are adjusted for clustering within state-education-experience cells. 
Table 17: IV Estimates using Alternative Specifications (men)

\section{Specification}

\begin{tabular}{|c|c|c|c|c|c|}
\hline & & & & & \\
\hline Specification & & Weekly Wage & Hourly Wage & $\begin{array}{l}\text { Employment to } \\
\text { Labor Force }\end{array}$ & $\begin{array}{l}\text { Employment to } \\
\text { Population }\end{array}$ \\
\hline 1. Full-time Only & $p_{i s t}$ & $\begin{array}{l}-0.69 * \star \star \\
(-4.60)\end{array}$ & $\begin{array}{l}-0.70 * \star \star \\
(-5.24)\end{array}$ & $\begin{array}{l}-0.34^{\star \star} \\
(-2.25)\end{array}$ & $\begin{array}{l}-0.38^{\star \star} \\
(-2.06)\end{array}$ \\
\hline & $p_{i s t} \times M W_{s t}$ & $\begin{array}{l}0.10^{\star \star \star} \\
(4.06)\end{array}$ & $\begin{array}{l}\mathbf{0 . 1 1} \\
(5.13)\end{array}$ & 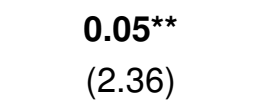 & $\begin{array}{l}\mathbf{0 . 0 6} \mathbf{6}^{\star \star} \\
(2.22)\end{array}$ \\
\hline $\begin{array}{l}\text { 2. Two-Year } \\
\text { Observations }(t=7)\end{array}$ & $p_{i s t}$ & $\begin{array}{l}-0.60 * \star \star \\
(-4.28)\end{array}$ & $\begin{array}{l}-0.58^{\star \star \star} \\
(-5.00)\end{array}$ & $\begin{array}{l}-0.41^{\star \star \star} \\
(-4.35)\end{array}$ & $\begin{array}{l}-0.45^{\star \star \star} \\
(-3.48)\end{array}$ \\
\hline & $p_{i s t} \times M W_{s t}$ & $\begin{array}{c}0.09^{\star \star \star} \\
(4.13)\end{array}$ & $\begin{array}{l}\mathbf{0 . 1 0} \\
(5.11)\end{array}$ & $\begin{array}{l}0.05^{\star \star \star} \\
(4.25)\end{array}$ & $\begin{array}{c}0.07^{\star \star \star} \\
(3.69)\end{array}$ \\
\hline $\begin{array}{l}\text { 3. Add Share of } \\
\text { Natives at the MW }\end{array}$ & $p_{i s t}$ & $\begin{array}{l}-0.55^{\star \star \star} \\
(-4.18)\end{array}$ & $\begin{array}{l}-0.51^{\star \star \star} \\
(-4.58)\end{array}$ & $\begin{array}{l}-0.42^{\star \star \star} \\
(-4.41)\end{array}$ & $\begin{array}{l}-0.46^{\star \star \star} \\
(-3.48)\end{array}$ \\
\hline and its interaction & $p_{i s t} \times M W_{s t}$ & $\begin{array}{l}0.10^{\star \star \star} \\
(4.70)\end{array}$ & $\begin{array}{l}0.10^{\star * *} \\
(5.67)\end{array}$ & $\begin{array}{c}0.06^{\star \star \star} \\
(4.45)\end{array}$ & $\begin{array}{l}\mathbf{0 . 0 6 ^ { \star \star \star }} \\
(3.55)\end{array}$ \\
\hline $\begin{array}{l}\text { 4. Alternative } M W= \\
E M W / \text { Median } W \text { age }\end{array}$ & $p_{i s t}$ & $\begin{array}{l}-0.99^{\star} \\
(-1.76)\end{array}$ & $\begin{array}{l}-0.60 \\
(-1.23)\end{array}$ & $\begin{array}{l}-0.90^{\star * *} \\
(-3.02)\end{array}$ & $\begin{array}{l}-0.99 * * \\
(-2.51)\end{array}$ \\
\hline & $p_{i s t} \times M W_{s t}$ & $\begin{array}{l}2.70^{*} \\
(1.83)\end{array}$ & $\begin{array}{c}1.70 \\
(1.34)\end{array}$ & $\begin{array}{l}2.35^{\star \star \star} \\
(3.05)\end{array}$ & $\begin{array}{l}2.62^{\star \star} \\
(2.58)\end{array}$ \\
\hline
\end{tabular}

\section{Dependent Variable}

Key. ${ }^{* * *},{ }^{* *},{ }^{*}$ denote statistical significance from zero at the $1 \%, 5 \%, 10 \%$ significance level. T-statistics are indicated in parentheses below the point estimate.

Notes. Each regression has around 22,848 observations (i.e., 4 education groups, 8 experience groups, 51 states and 14 years of data), except specification 2 which has 11,424 observations. We weight wage regressions by the share of natives used to compute the dependent variable per year. The employment regressions are weighted by the share of the native labor force for a given year across cells. Standard errors are adjusted for clustering within state-education-experience cells. 
Table 18: IV Estimates for low Minimum Wage States using $\hat{p}_{i s t}^{\text {dist }}$ as an Alternative Instrument

\begin{tabular}{|c|c|c|c|c|c|}
\hline \multicolumn{2}{|l|}{ Specification } & Weekly Wage & Hourly Wage & $\begin{array}{l}\text { Employment to } \\
\text { Labor Force }\end{array}$ & $\begin{array}{c}\text { Employment to } \\
\text { Population }\end{array}$ \\
\hline & & \multicolumn{4}{|c|}{ A. $\hat{p}_{i s t}^{d i s t}$ and $\hat{p}_{i s t}^{d i s t} \times M W_{t}$ as Instruments } \\
\hline \multirow[t]{4}{*}{ 1. Men } & $p_{i s t}$ & $-0.76^{\star \star *}$ & $-0.66^{\star \star \star}$ & $-0.51^{\star \star \star}$ & $-0.75^{\star \star \star}$ \\
\hline & & $(-4.27)$ & $(-4.34)$ & $(-4.96)$ & $(-5.31)$ \\
\hline & $p_{i s t} \times M W_{s t}$ & $0.09^{\star \star \star}$ & $0.11^{\star \star \star}$ & $0.06^{\star \star \star}$ & $0.11^{\star \star \star}$ \\
\hline & & $(2.58)$ & $(3.33)$ & $(3.44)$ & $(4.05)$ \\
\hline \multirow[t]{5}{*}{ 2. Men and Women } & $p_{i s t}$ & $-0.71^{\star * *}$ & $-0.53^{\star * *}$ & $-0.52^{\star \star \star}$ & $-0.81^{* * *}$ \\
\hline & & $(-4.51)$ & $(-4.17)$ & $(-5.47)$ & $(-6.17)$ \\
\hline & $p_{i s t} \times M W_{s t}$ & $0.11^{\star * \star}$ & $0.09^{* * *}$ & $0.06^{\star \star \star}$ & $0.12^{\star \star \star}$ \\
\hline & & $(4.15)$ & $(3.93)$ & $(4.13)$ & $(5.08)$ \\
\hline & & \multicolumn{4}{|c|}{ B. $\hat{p}_{i s t}^{d i s t}$ and $\hat{p}_{i s t}^{d i s t} \times F M W_{t}$ as Instruments } \\
\hline \multirow[t]{4}{*}{ 3. Men } & $p_{i s t}$ & $-0.89^{\star \star}$ & $-0.91^{\star \star \star}$ & $-1.12^{\star \star \star}$ & $-2.00 * \star \star$ \\
\hline & & $(-2.34)$ & $(-2.78)$ & $(-5.19)$ & $(-6.34)$ \\
\hline & $p_{i s t} \times M W_{s t}$ & 0.12 & $0.16^{\star *}$ & $0.19^{\star * *}$ & $0.37^{\star \star \star}$ \\
\hline & & $(1.43)$ & $(2.11)$ & $(4.24)$ & $(5.43)$ \\
\hline \multirow[t]{4}{*}{ 4. Men and Women } & $p_{i s t}$ & $-1.45^{\star \star \star}$ & $-1.12^{\star \star \star}$ & $-1.07^{\star \star \star}$ & $-2.03^{\star \star \star}$ \\
\hline & & $(-4.46)$ & $(-4.48)$ & $(-5.46)$ & $(-7.04)$ \\
\hline & $p_{i s t} \times M W_{s t}$ & $0.27^{\star \star \star}$ & $0.22^{\star \star \star}$ & $0.18^{\star \star \star}$ & $0.38^{\star \star \star}$ \\
\hline & & $(3.85)$ & $(3.82)$ & $(4.73)$ & $(6.35)$ \\
\hline
\end{tabular}

Key. ${ }^{* * *},{ }^{* *},{ }^{*}$ denote statistical significance from zero at the $1 \%, 5 \%, 10 \%$ significance level. T-statistics are indicated in parentheses below the point estimate.

Notes. Each regression has around 18,816 observations (i.e., 4 education groups, 8 experience groups, 42 states and 14 years of data). We weight wage regressions by the share of natives used to compute the dependent variable per year. The employment regressions are weighted by the share of the native labor force for a given year across cells. Standard errors are adjusted for clustering within state-education-experience cells. 


\section{E Additional DiD Estimates}


Table 5: OLS and IV Estimates for Low Minimum Wage States

Specification

\author{
Weekly Wage Hourly Wage Labor Force
}

\section{A. OLS Estimates}

\begin{tabular}{|c|c|c|c|c|c|}
\hline \multirow{3}{*}{ 1. Men } & \multirow[b]{2}{*}{$p_{\text {ist }}$} & & & & \\
\hline & & $-0.24^{\star \star \star}$ & $-0.31^{\star \star \star}$ & $-0.20^{\star \star \star *}$ & $-0.40^{\star * *}$ \\
\hline & & $(-2.60)$ & $(-3.76)$ & $(-3.61)$ & $(-4.83)$ \\
\hline \multirow{6}{*}{ 2. Men and Women } & \multirow[t]{2}{*}{$p_{i s t} \times M W_{s t}$} & $0.04^{\star *}$ & $0.05^{\star \star \star}$ & $0.04^{\star * \star}$ & $0.04^{\star * \star}$ \\
\hline & & $(2.19)$ & (3.34) & (3.33) & $(2.82)$ \\
\hline & \multirow[t]{2}{*}{$p_{i s t}$} & $-0.25^{\star \star \star}$ & $-0.25^{\star \star \star}$ & $-0.21^{\star \star \star}$ & $-0.54^{\star \star \star}$ \\
\hline & & $(-3.06)$ & $(-3.36)$ & $(-4.17)$ & $(-6.64)$ \\
\hline & \multirow[t]{2}{*}{$p_{i s t} \times M W_{s t}$} & $0.04^{\star \star \star}$ & $0.04^{\star \star \star}$ & $0.04^{\star \star \star}$ & $0.07^{\star \star \star}$ \\
\hline & & $(2.82)$ & $(3.16)$ & $(4.09)$ & $(4.28)$ \\
\hline
\end{tabular}

B. IV using $\hat{p}_{i s t}$ and $\hat{p}_{i s t} \times M W_{t}$ as Instruments

\begin{tabular}{|c|c|c|c|c|c|}
\hline \multirow{3}{*}{ 3. Men } & \multirow[b]{2}{*}{$p_{i s t}$} & & & & \\
\hline & & $-0.57^{\star \star \star}$ & $-0.54^{\star \star \star}$ & $-0.48^{\star \star \star}$ & $-0.60^{\star \star \star}$ \\
\hline & \multirow{3}{*}{$p_{i s t} \times M W_{s t}$} & $(-4.08)$ & $(-4.48)$ & $(-4.74)$ & $(-4.33)$ \\
\hline \multirow{5}{*}{ 4. Men and Women } & & $0.06^{\star \star}$ & $0.07^{\star \star \star}$ & $0.06^{\star \star \star}$ & $0.09^{\star \star \star}$ \\
\hline & & $(2.33)$ & $(3.35)$ & $(4.76)$ & $(4.64)$ \\
\hline & \multirow[t]{2}{*}{$p_{i s t}$} & $-0.49^{\star \star \star}$ & $-0.41^{\star \star \star}$ & $-0.41^{\star \star \star}$ & $-0.63^{\star \star \star}$ \\
\hline & & $(-3.92)$ & $(-3.91)$ & $(-4.82)$ & $(-5.09)$ \\
\hline & $p_{i s t} \times M W_{s t}$ & $0.07^{\star \star *}$ & $0.07^{* \star *}$ & $0.06^{\star * *}$ & $0.11^{* * *}$ \\
\hline
\end{tabular}

\begin{tabular}{|c|c|c|c|c|c|}
\hline \multirow{3}{*}{ 5. Men } & \multirow[b]{2}{*}{$p_{\text {ist }}$} & \multicolumn{4}{|c|}{ C. IV using $\hat{p}_{i s t}$ and $\hat{p}_{i s t} \times F M W_{t}$ as Instruments } \\
\hline & & $-0.72 * \star \star$ & $-0.70^{\star * \star}$ & $-1.01^{\star \star \star}$ & $-1.55^{\star \star \star}$ \\
\hline & & $(-2.85)$ & $(-3.36)$ & $(-6.54)$ & $(-6.92)$ \\
\hline \multirow{6}{*}{ 6. Men and Women } & \multirow{2}{*}{$p_{i s t} \times M W_{s t}$} & $0.08^{*}$ & $0.10^{\star \star}$ & $0.16^{\star \star \star}$ & $0.26^{\star \star \star}$ \\
\hline & & $(1.65)$ & $(2.27)$ & $(5.77)$ & $(6.35)$ \\
\hline & \multirow[t]{2}{*}{$p_{\text {ist }}$} & $-0.93^{\star \star \star}$ & $-0.73^{\star \star \star}$ & $-0.91^{\star \star \star}$ & $-1.73^{\star \star \star}$ \\
\hline & & $(-4.07)$ & $(-4.25)$ & $(-6.58)$ & $(-7.71)$ \\
\hline & \multirow[t]{2}{*}{$p_{i s t} \times M W_{s t}$} & $0.15^{\star \star \star}$ & $0.13^{\star \star \star}$ & $0.15^{\star \star \star}$ & $0.31^{\star \star \star}$ \\
\hline & & $(3.40)$ & (3.44) & $(6.25)$ & $(7.33)$ \\
\hline
\end{tabular}

Key. ${ }^{* * *},{ }^{* *},{ }^{*}$ denote statistical significance from zero at the $1 \%, 5 \%, 10 \%$ significance level. T-statistics are indicated in parentheses below the point estimate.

Notes. Each regression has around 18,816 observations (i.e., 4 education groups, 8 experience groups, 42 states and 14 years of data). We weight wage regressions by the share of natives used to compute the dependent variable per year. The employment regressions are weighted by the share of the native labor force for a given year across cells. Standard errors are adjusted for clustering within state-education-experience cells. 
Table 7: The Effects of immigration on the Wages and Employment of Low-skilled Native Workers

\begin{tabular}{|c|c|c|c|c|c|}
\hline \multirow[t]{2}{*}{ Specification } & & Weekly Wage & Hourly Wage & $\begin{array}{l}\text { Employment to } \\
\text { Labor Force }\end{array}$ & $\begin{array}{c}\text { Employment to } \\
\text { Population }\end{array}$ \\
\hline & & \multicolumn{4}{|c|}{ A. Years of Experience $<10$} \\
\hline \multirow{4}{*}{$\begin{array}{l}\text { 1. OLS Estimates } \\
\text { Men }\end{array}$} & $p_{\text {ist }}$ & $-0.53^{\star \star}$ & $-0.45^{\star \star \star}$ & $-0.29^{\star}$ & $-0.43^{\star}$ \\
\hline & & $(-2.46)$ & $(-2.79)$ & $(-1.95)$ & $(-1.87)$ \\
\hline & $p_{i s t} \times M W_{s t}$ & $0.08^{\star \star}$ & $0.07^{\star \star}$ & $0.06^{\star \star}$ & 0.06 \\
\hline & & $(2.08)$ & $(2.50)$ & $(2.05)$ & $(1.30)$ \\
\hline \multicolumn{2}{|l|}{ 2. IV Estimates } & $-1.11^{\star \star \star}$ & $-0.88^{\star \star \star}$ & $-0.88^{\star \star \star}$ & $-1.31^{\star \star \star}$ \\
\hline \multirow[t]{3}{*}{ Men } & & $(-3.87)$ & $(-3.89)$ & $(-3.30)$ & $(-3.35)$ \\
\hline & & $0.11^{\star \star}$ & $0.13^{\star \star \star}$ & $0.10^{\star \star *}$ & $0.09^{\star \star}$ \\
\hline & & $(2.10)$ & (2.62) & $(2.68)$ & $(2.25)$ \\
\hline \multirow{4}{*}{$\begin{array}{l}\text { 3. IV Estimates } \\
\text { Men and Women }\end{array}$} & $p_{\text {ist }}$ & $-1.09 * \star \star$ & $-0.83^{\star \star \star}$ & $-0.88^{\star \star \star}$ & 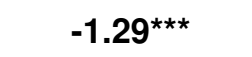 \\
\hline & & $(-3.49)$ & $(-3.61)$ & $(-2.99)$ & $(-3.00)$ \\
\hline & $p_{i s t} \times M W_{s t}$ & $0.14^{\star \star}$ & $0.14^{\star \star *}$ & $0.13^{\star \star}$ & $0.11^{*}$ \\
\hline & & $(2.41)$ & $(2.71)$ & $(2.36)$ & $(1.84)$ \\
\hline
\end{tabular}

B. Years of Experience $<10$ and less than College Education

\begin{tabular}{|c|c|c|c|c|c|}
\hline \multirow{2}{*}{$\begin{array}{l}\text { 4. IV Estimates } \\
\text { Men }\end{array}$} & $p_{i s t}$ & $\begin{array}{l}-1.16^{\star \star *} \\
(-4.22)\end{array}$ & $\begin{array}{l}-0.77^{\star \star *} \\
(-3.68)\end{array}$ & $\begin{array}{l}-0.71^{\star \star *} \\
(-3.44)\end{array}$ & $\begin{array}{c}-1.08^{\star \star *} \\
(-2.85)\end{array}$ \\
\hline & $p_{i s t} \times M W_{s t}$ & 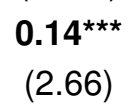 & $\begin{array}{l}0.10^{\star *} \\
(2.19)\end{array}$ & 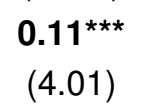 & $\begin{array}{l}0.10^{\star *} \\
(2.52)\end{array}$ \\
\hline \multirow[t]{2}{*}{$\begin{array}{l}\text { 5. IV Estimates } \\
\text { Men and Women }\end{array}$} & $p_{i s t}$ & $\begin{array}{l}-0.61^{\star *} \\
(-1.98)\end{array}$ & $\begin{array}{l}-0.39^{\star} \\
(-1.76)\end{array}$ & $\begin{array}{c}-0.71^{\star \star \star} \\
(-2.90)\end{array}$ & $\begin{array}{l}-0.84^{\star \star} \\
(-1.97)\end{array}$ \\
\hline & $p_{i s t} \times M W_{s t}$ & $\begin{array}{c}\mathbf{0 . 0 9}^{\star} \\
(1.68)\end{array}$ & $\begin{array}{c}\mathbf{0 . 0 5} \\
(1.23)\end{array}$ & 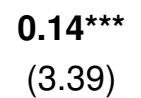 & $\begin{array}{l}\mathbf{0 . 0 8}^{\star \star} \\
(2.37)\end{array}$ \\
\hline
\end{tabular}

Key. ${ }^{* * *},{ }^{* *},{ }^{*}$ denote statistical significance from zero at the $1 \%, 5 \%, 10 \%$ significance level. T-statistics are indicated in parentheses below the point estimate.

Notes. The regressions in Panels A and B respectively have 2,856 and 1,428 observations. We weight wage regressions by the share of natives used to compute the dependent variable per year. The employment regressions are weighted by the share of the native labor force for a given year across cells. Standard errors are adjusted for clustering at the education-state level. 


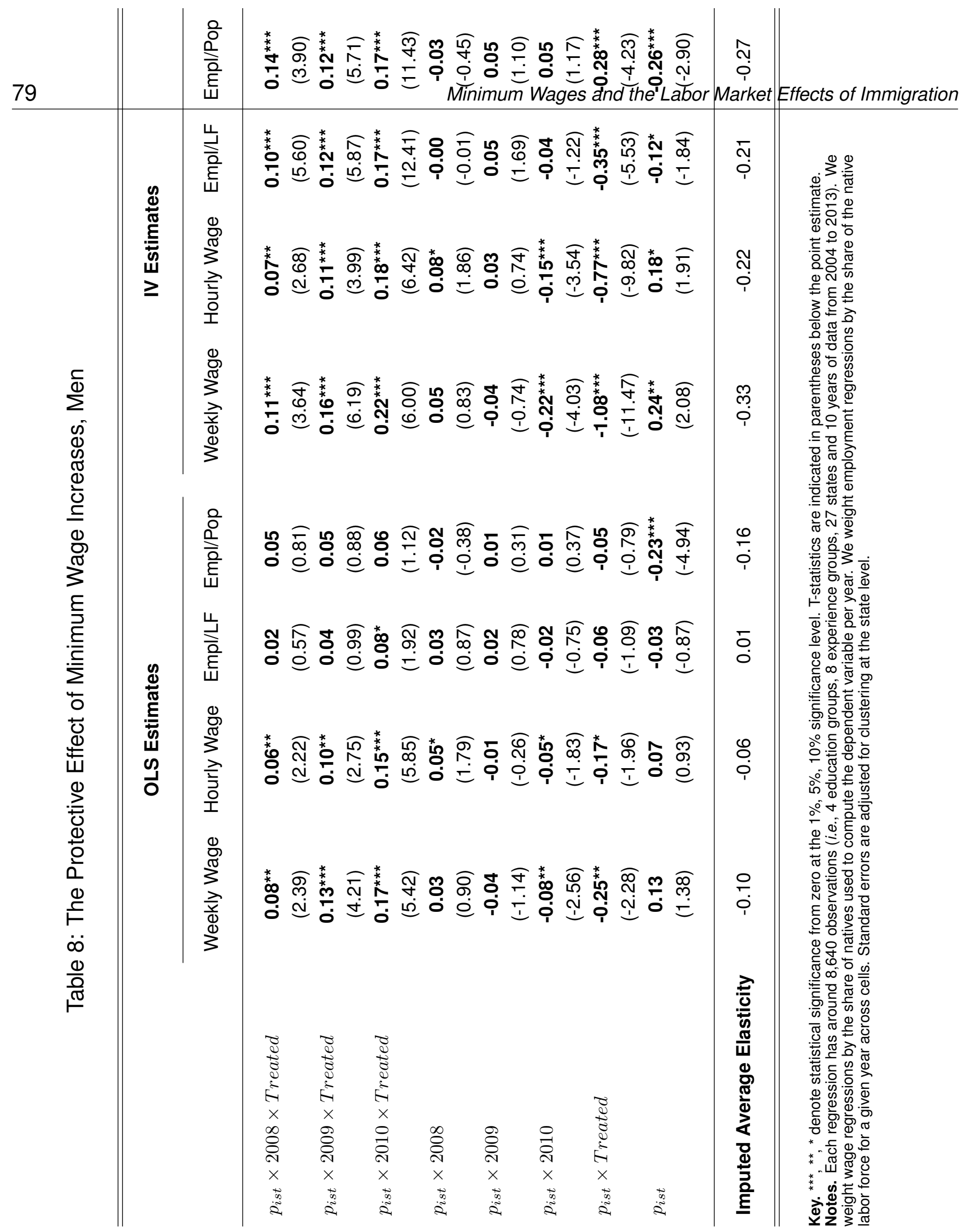




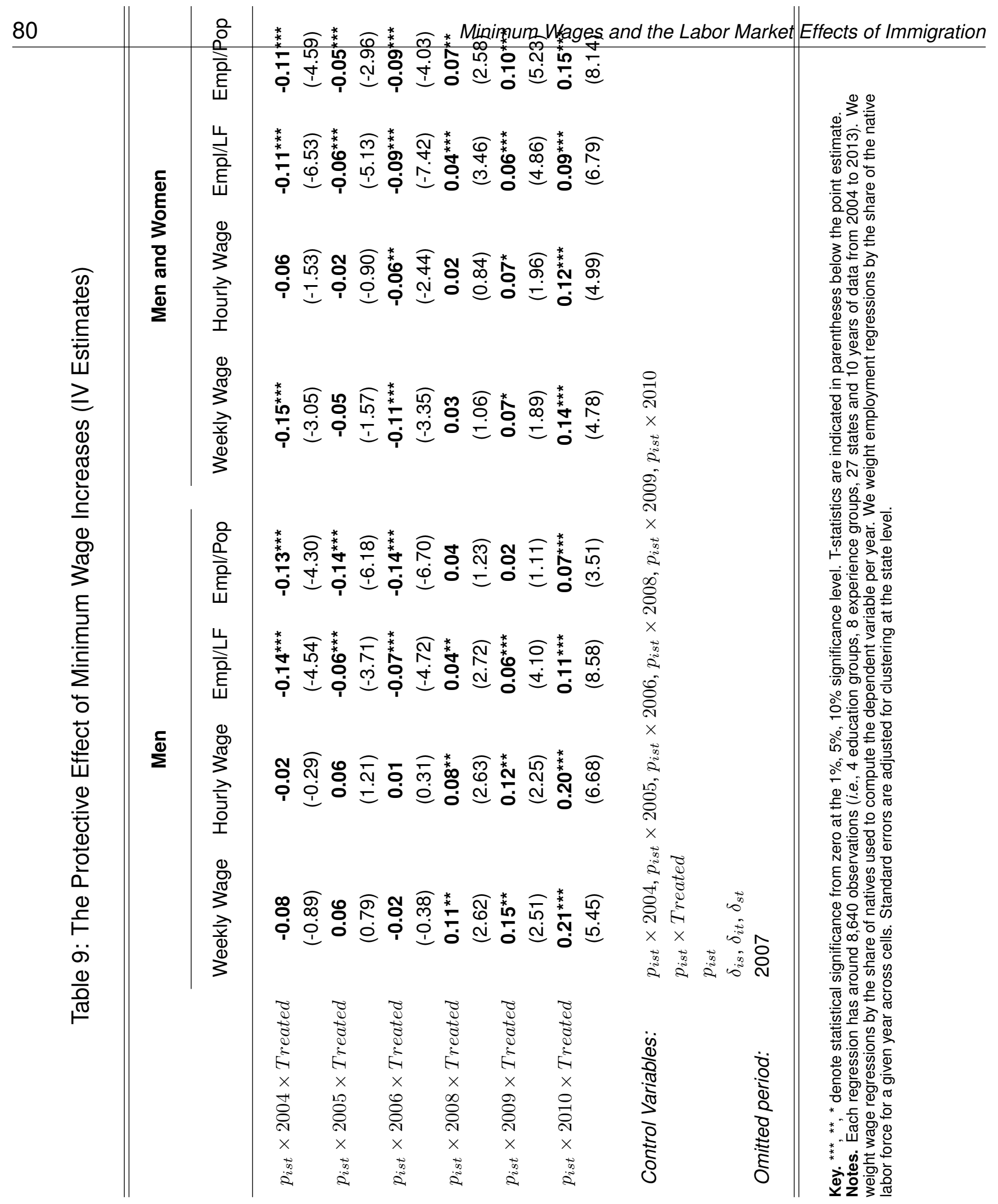


Table 10: The Protective Effects of the Minimum Wage in Low MW States

\begin{tabular}{|c|c|c|c|c|c|}
\hline & $2004-2007$ & 2008 & 2009 & After 2010 & $2004-2013$ \\
\hline Federal Minimum Wage (in 1999 dollars) & $\$ 4.3$ & $\$ 4.5$ & $\$ 5.1$ & $\$ 5.3$ & $\$ 4.8$ \\
\hline$\%$ Increase in the FMW & - & 13.6 & 12.0 & 10.7 & 40.8 \\
\hline$\%$ Workers at the Minimum Wage & 4.7 & 6.1 & 7.4 & 10.0 & 7.2 \\
\hline \multicolumn{6}{|l|}{ Implied Wage Elasticity } \\
\hline A1. With the actual FMW Increases & -0.57 & -0.50 & -0.46 & -0.57 & -0.55 \\
\hline A2. Without FMW Increases & -0.57 & -0.57 & -0.57 & -0.72 & -0.63 \\
\hline$\%$ Reduction in the Elasticity & - & 13.1 & 19.0 & 20.8 & 12.4 \\
\hline \multicolumn{6}{|l|}{ Implied Employment Elasticity } \\
\hline B1. With the actual FMW Increases & -0.32 & -0.25 & -0.24 & -0.20 & -0.26 \\
\hline B2. Without FMW Increases & -0.32 & -0.32 & -0.32 & -0.32 & -0.32 \\
\hline$\%$ Reduction in the Elasticity & - & 21.3 & 25.5 & 36.2 & 19.1 \\
\hline \multicolumn{6}{|l|}{ Wage Losses for an Annual Salary of $\$ 20,000$} \\
\hline With the actual FMW Increases (a) & $\$ 1,142$ & $\$ 993$ & $\$ 925$ & $\$ 1,142$ & $\$ 1,106$ \\
\hline Without FMW Increases (b) & $\$ 1,142$ & $\$ 1,142$ & $\$ 1,142$ & $\$ 1,442$ & $\$ 1,262$ \\
\hline$(b)-(a)$ & - & $\$ 150$ & $\$ 218$ & $\$ 299$ & $\$ 156$ \\
\hline Protective Effect of the FMW $((b-a) / \$ 20,000)$ & - & 0.7 & 1.1 & 1.5 & 0.6 \\
\hline
\end{tabular}




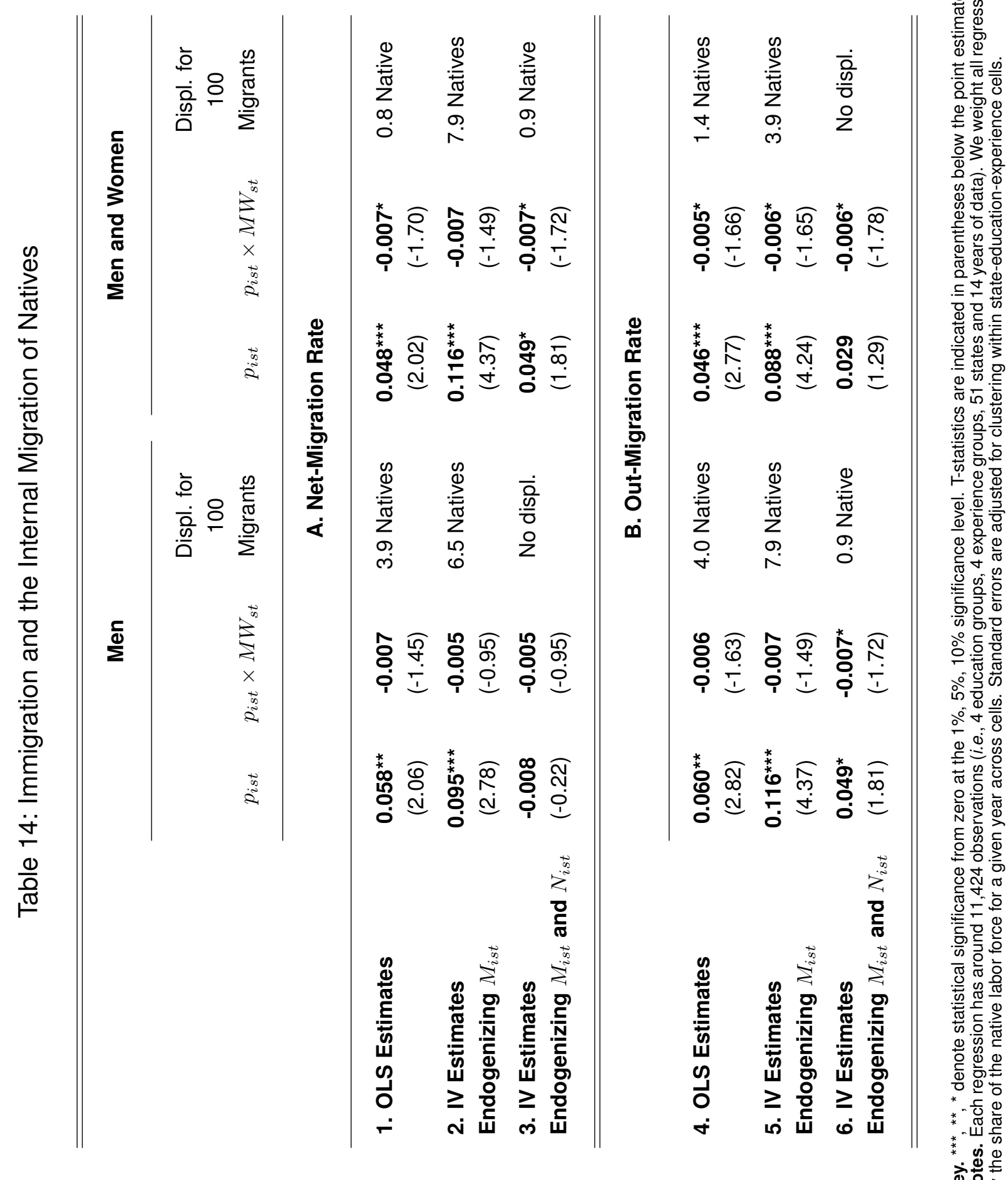




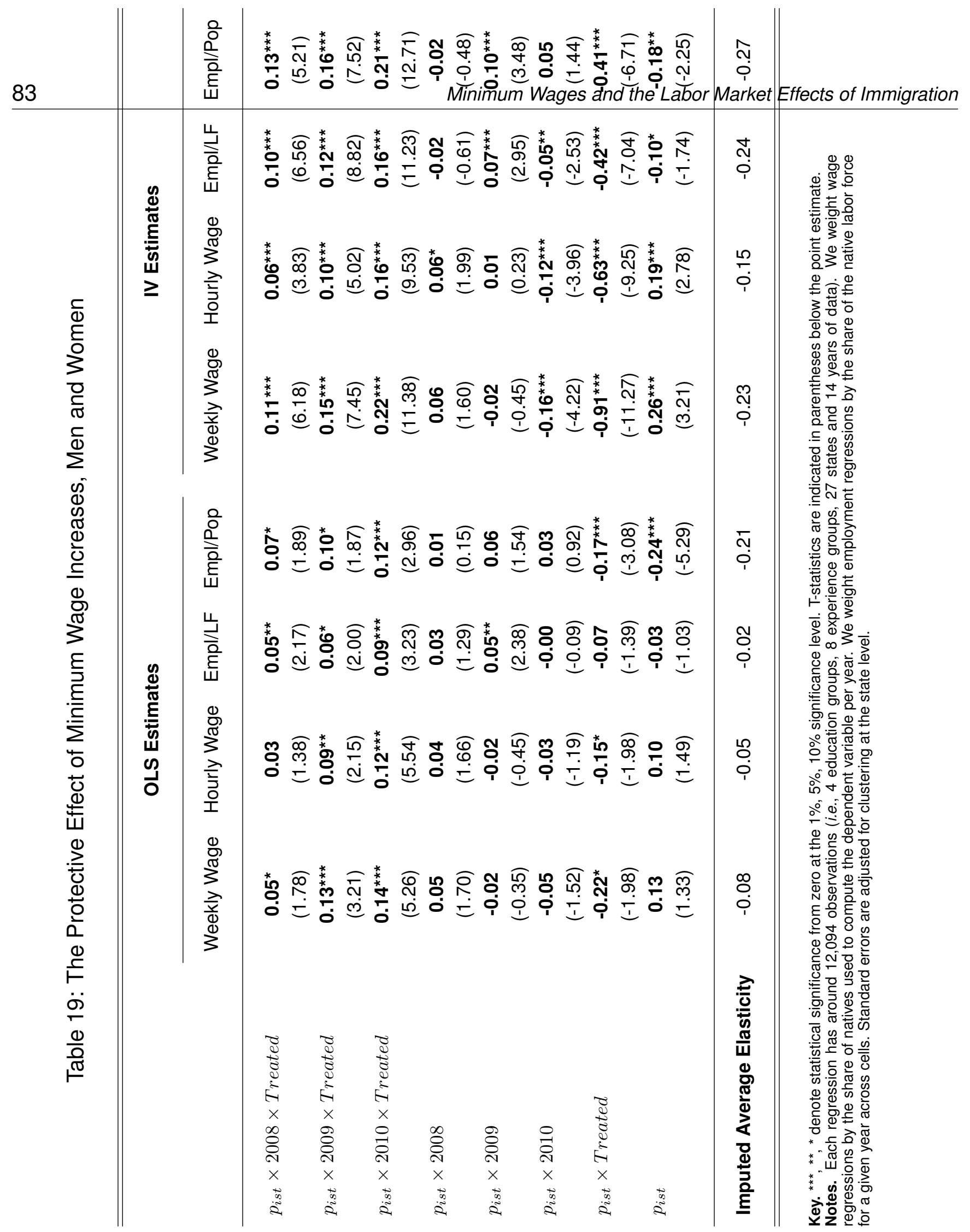

